TECHNICAL REPORT NO. 3-722

\title{
EMBANKMENT PORE PRESSURES DURING CONSTRUCTION \\ by
}

G. W. Clough
J. W. Snyder

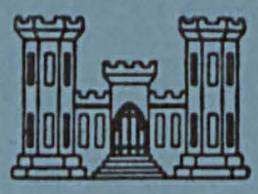

May 1966

\author{
Sponsored by \\ Office, Chief of Engineers \\ U. S. Army
}

Conducted by

U. S. Army Engineer Waterways Experiment Station CORPS OF ENGINEERS

Vicksburg, Mississippi

DISTRIBUTION OF THIS DOCUMENT IS UNLIMITED 
TECHNICAL REPORT NO. 3-722

\title{
EMBANKMENT PORE PRESSURES DURING CONSTRUCTION \\ by
}

G. W. Clough

J. W. Snyder

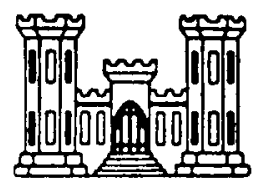

May 1966

\author{
Sponsored by \\ Office, Chief of Engineers \\ U. S. Army
}

Conducted by

U. S. Army Engineer Waterways Experiment Station CORPS OF ENGINEERS

Vicksburg, Mississippi 
FOREWORD

A review of methods for estimating embankment construction pore pressures was made, and a summary of observed pore pressures in embankments constructed by the Corps of Engineers and other agencies was compiled by the U. S. Army Engineer Waterways Experiment Station (WES) at the request of the Office, Chief of Engineers (OCE). This study was authorized and initiated under CWI 531 (now ES 531) in fiscal year 1963.

The study was based primarily on information received from other Corps of Engineers offices and obtained from a literature search. Engineers engaged in the study included Miss M. A. Ledbetter, Mr. J. W. Snyder, and Mr. G. W. Clough, Embankment and Foundation Branch, Soils Division, WES. This report was prepared by Mr. Clough and Mr. Snyder under the general supervision of Messrs. W. J. Turnbull, A. A. Maxwell, J. R. Compton, and W. C. Sherman, Jr., of the Soils Division, and was reviewed and approved by OCE prior to publication.

Directors of the WES during this study and the preparation of this report were Col. Alex G. Sutton, Jr., CE, and Col. John R. Oswalt, Jr., CE. Technical Director was Mr. J. B. Tiffany. 
FOREWORD

PART II: METHODS OF ESTIMATING EIMBAINKMENT PORE PRESSURES

Bruggeman, Zanger, and Brahtz (1939) Hilf (1948)

Rufenacht (1948)

Skempton and Bishop (1954)

Bishop (1957)

Bernell and Nilsson (1957)

Li (1959)

other References.

Historical Trends

PART III: PRESENTATION AND ANAIYSIS OF DATA FROM DAMS . . . . . . . 24

Sources of Data . . . . . . . . . . . . . . . . . . . . 24

Pore Pressure Ratio . . . . . . . . . . . . . . . . . 24

Piezometric Contours During and at the End of Construction

of CE Dams . . . . . . . . . . . . . . . . . . . . 25

Pore Pressure Versus Overburden Pressure . . . . . . . . . . . 31

Factors Influencing the Magnitude of the Pore Pressure Ratio

at the End of Construction . . . . . . . . . . . . . . . 34

Summary . . . . . . . . . . . . . . . . . . . 42

PART IV: CONCLUSTONS AIND RECOMMENDATIONS . . . . . . . . . . . . . . 44

Conclusions . . . . . . . . . . . . . . . . . . . . 44

Recommendations . . . . . . . . . . . . . . . . 45

SELECTED BIBLIOGRAPHY . . . . . . . . . . . . . . . . . . . . . . . 46 TABLES $1-4$

PLATES $1-19$ 
APPENDIX A: WES MULTIPIE IETTER

TABLE AI

APPENDIX B: PIEZOMETER SYSTEMS OF EARTH DAMS USED IN THIS STUDY TABIE BI

FIGS. BI-B7 
1 Method of predicting construction pore pressures ( $\mathrm{Hilf}^{25}$ ).

2 Relation between pore pressure and total stress for the case of partial dissipation of pore pressure (Bishop9). .

Results of a typical set of calculations with 50 percent dissipation of pore pressure between each loading stage compared with zero dissipation (Bishop')

Derivation of pore pressure and total stress versus compression relation for case of one-third dissipation ( $\mathrm{Li}^{29}$ )

Pore pressures in a wet compacted fill during consolidation at constant load, $\mathrm{H}=10 \mathrm{~m}$ (Bernell $\left.{ }^{4}\right)$. . . . . . . .

Pore pressures in a wet compacted fill during consolidation at constant load, $\mathrm{H}=20 \mathrm{~m}$ (Bernell ${ }^{4}$ ).........

Laboratory time-compression curve . . . . . . . . . . . .

Theoretical curve of consolidation ratio versus time factor for saturated soils . . . . . . . . . . . . . . .

10 Hypothetical representation of Bishop's hypothesis (Bishop9).....................

11 Maximum pore pressure ratio at end of construction versus water content . . . . . . . . . . . . . . .

12 Maximum pore pressure at end of construction versus fill height for dams compacted at over 2 percent wet or dry of optimum

13 Maximum pore pressure ratios at end of construction versus fill height for dams compacted 0 to 2 percent dry of optimum . . . . . . . . . . . . . . . . . . Maximum pore pressure ratios at end of construction versus fill height for dams compacted 0 to 2 percent wet of optimum Plasticity chart showing relative consistency of impervious soils of dams used in this study . . . . . . . . . . .

Bl Piezometer tip types $A, B$, and $C$ Piezometer tip types $\mathrm{D}, \mathrm{F}$, and $\mathrm{G}$, and well point screen type $\mathrm{E}$. . . . . . . . . . . . . . . . . . . . . 
List of Tables

Table

1 CE Dams

Placement and Pore Pressure Data for Impervious Core Zones, USBR Dams

3 Placement and Pore Pressure Data for Impervious Core Zones, Foreign Dams

4 Selected Piezometer Data for Selected Dams

Al Embankment Pore Pressure Study, Division Offices Response to WES Letter of 28 June 1963

B1 Piezometer Systems of Dams Used in Study

\section{Iist of Plates}

Title

1 Piezometric contours at end of construction, Table Rock Dam Piezometric contours at different stages, Blakely Mountain Dam Piezometric levels at end of construction, Otter Brook Dam Piezometric contours at different stages, Mad River Dam Piezometric levels at different stages, North Hartland Dam Piezometric levels at end of construction, Porme de Terre Dam Piezometric levels at different stages, Hills Creek Dam Piezometric levels at end of construction, Dewey Dam Piezometric levels at end of construction, Texarkana Dam

11

12

13

14

15

16 Piezometric levels at end of construction, Ferrell's Bridge Dam Plot of $\mu$ vs $\sigma_{1}$, Anderson Ranch Dam Plot of $\mu$ vs $\sigma_{1}^{1}$, Green Mountain Dam Plot of $\mu$ vs $\sigma_{1}^{1}$, Granby Dam Plot of $\mu$ vs $\sigma_{1}^{\perp}$, Otter Brook Dam Plot of $\mu$ vs $\sigma_{1}$, Mad River Dam Plot of $\mu$ vs $\sigma_{1}^{1}$, North Hartland Dam Plot of $\mu$ vs $\sigma_{1}^{1}$, Hills Creek Dam Maximum pore pressure ratios in CE dams Plot of $\mu$ vs $\sigma_{1}^{1}$, Vallecito Dam 


\section{SUMMARY}

The purpose of this study was to summarize observed pore pressure data from CE dams and published data from other agencies on methods of predicting and determining the development of pore water pressure in earth dams. A summary of theoretical methods for predicting pore pressures is included to assist in the interpretation of the selected data from $\mathrm{CE}$, USBR, and foreign sources presented herein.

Construction characteristics and pore pressure data from $10 \mathrm{CE}$ dams, 24 USBR dams, and 9 foreign dams are summarized and compared in an effort to draw conclusions on construction pore pressures in earth embankments. This study determined that because of the numerous factors which influence pore pressure buildup, broad conclusions for all earth dams are very difficult to make and each dam must be treated individually with respect to predicting construction pore pressures.

Conclusions indicated as a result of this study are:

a. Provisions for internal drainage effectively relieve construction pore pressures in earth embankments.

b. Pore pressure ratios in embankment materials increase rapidly as placement water content increases, especially above optimum water content.

c. Pore pressures increase with increasing dam height, but even low dams (less than $100 \mathrm{ft}$ in height) can develop large pore pressures.

It is recommended that standardization of piezometer installations and data recording would facilitate obtaining useful information for further understanding of the factors affecting pore pressure development.

Included in this report are a selected bibliography of pore pressure literature, and, in appendixes, a tabulation of $\mathrm{CE}$ division office responses to the data request for this study and sketches of different piezometer tips used in dams included in this study. 


\section{PART I: INTRODUCTION}

\section{Purpose}

1. Methods available to design engineers for predicting the development of pore pressures during the construction of earth dams are quite numerous but, unfortunately, few have proven reliable or have general application. For this reason, many practicing designers have used a "rule of thumb" approach for estimating construction pore pressures, which is generally based on past experience. This approach assumes that the pore pressure at a given point will be equal to a certain percentage of the overburden pressure. This approach is of questionable value and does not provide any certainty of the safety of the design. The Office, Chief of Engineers, therefore requested the U. S. Army Engineer Waterways Experiment Station (WES) to review various theoretical methods for predicting construction pore pressures and to prepare a summary of observed pore-pressure data from the files of Corps of Engineers (CE) offices and published data from other agencies.

\section{$\underline{\text { Scope }}$}

2. Familiarity with the theoretical methods for predicting construction pore pressures provides an insight to the variation of these pore pressures with different soil types, placement conditions, etc. To facilitate understanding of the various theoretical methods, they have been summarized in Part II.

3. In addition to the review that was made of theoretical methods for estimating pore pressures during construction, embankment pore pressure data recorded by the $\mathrm{CE}$ were collected and summarized. These data were furnished in response to a letter dated 28 June 1963 (see Appendix A) sent by WES to all CE division offices. Table Al is a summary of the responses to this letter with comments as to the utilization of the data furnished 
in the study. In several cases, the data provided were not pertinent to the objectives of the study. For instance, pore pressures indicated by piezometers installed after construction was completed could not be considered, since they probably reflected time lag as well as seepage and/or dissipation effects and did not apply to conditions during or at the end of construction. The pore pressure data used in the study consisted of measurements in the embankment soils only during or after construction as indicated by piezometers installed prior to the completion of the dam. Only those data recommended by the respective division offices as being reliable were utilized.

4. In addition to the data obtained from sources within the CE, WES made a literature search to obtain data from other agencies engaged in earth dam construction. These data, along with the data from CE sources, are presented and analyzed subsequently in Parts III and IV. 
PART II: METHODS OF ESTTMATTIG EMBANKMEINT PORE

PRESSURES DURING CONSTRUCTION

\section{Bruggeman, Zanger, and Brahtz (1939)}

5. The first analytical method for dealing with construction pore pressures in an embankment was published by the U. S. Bureau of Reclamation (USBR) in 1939. ${ }^{13}$ Pore pressures in a transient state could be determined by the method provided certain physical characteristics of the soil were known. The theory is relatively complex and is not presented here. The basic development rests on the assumption that the time rate of change of the sum of the volumes of the moisture and the free air in an earth mass is caused by: (a) flow into the unit volume due to percolation, and (b) change in the free air volume due to changes in pressure and temperature. This time rate of change is equated to the time rate of consolidation, and the integration of this equation provides the solution for the problem of transient pore pressures.

6. Although this method provided a solution to the problem of transient construction pore pressures, later criticisms of its basic assumptions and procedure have limited its use. $\mathrm{Hilf}^{25}$ in 1948 proposed the assumption of no drainage to avoid the mathematical difficulties associated with the unsteady state of flow. In the same article, Hilf criticized the assumption of a constant bulk modulus for a soil to obtain solutions for dissipation of pore pressure. In $1956 \mathrm{Hilf}^{26}$ proposed that the neglect of surface tension used in the method was not justified. Tcherepennikoff 44 in 1955 questioned the use of Boyle's law to express the compressibility of air by assuming a constant temperature throughout the embankment, since he had observed that there was an increase in temperature in the lower part of the fill. Although the method developed by Bruggeman et al has fallen into disuse, its initial value cannot be denied since it provided a solution when there were no others.

Raised numerals refer to similarly numbered items in Selected Bibliography at end of text. 
7. Utilizing the groundwork laid by Bruggeman et al, ${ }^{13}$ but avoiding complicated mathematical difficulties by assuming a condition of no drainage, Hilf $f^{25}$ developed a simplified approach to the estimation of embankment pore pressures during construction. With a condition of no drainage, Bruggeman et al had postulated that the pore water pressure in a consolidating soil could be related to the amount of compression by combining Boyle's law for the compressibility of air with Henry's law for the solubility of air in water. Hilf expressed this by the equation

$$
u=\frac{P_{a} \Delta}{V_{a}+H_{w}-\Delta}
$$

where

$$
\begin{aligned}
\mathrm{u}= & \text { total air pressure after consolidation minus atmospheric pressure } \\
\mathrm{P}_{\mathrm{a}}= & \text { air pressure after compaction } \\
\Delta= & \text { consolidation or volume change in percentage of initial volume of } \\
& \text { soil mass } \\
\mathrm{V}_{\mathrm{a}}= & \text { volume of free air in the voids after compaction in percentage of } \\
& \text { initial volume of soil mass } \\
\mathrm{H}= & \text { Henry's constant of solubility of air in water by volume } \\
\mathrm{V}_{\mathrm{W}}= & \text { volume of water in the voids in percentage of initial volume of } \\
& \text { soil mass }
\end{aligned}
$$

Upon saturation of the soil mass by pressure, $\Delta=\mathrm{V}_{\mathrm{a}}$, and the expression is reduced to

$$
\mathrm{u}=\frac{\mathrm{P}_{\mathrm{a}} \mathrm{V}_{\mathrm{a}}}{\mathrm{HV} \mathrm{w}_{\mathrm{w}}}
$$

This relation is correct as long as no drainage occurs and if the surface tension can be neglected (i.e. if air pressure equals pore water pressure).

8. With the relation between pore water pressure and compression thus established by equations 1 and 2 , Hilf used the laboratory consolidation test to relate effective stress to compression by plotting a consolidation-stress curve from the test (fig. 1). Both relations are 

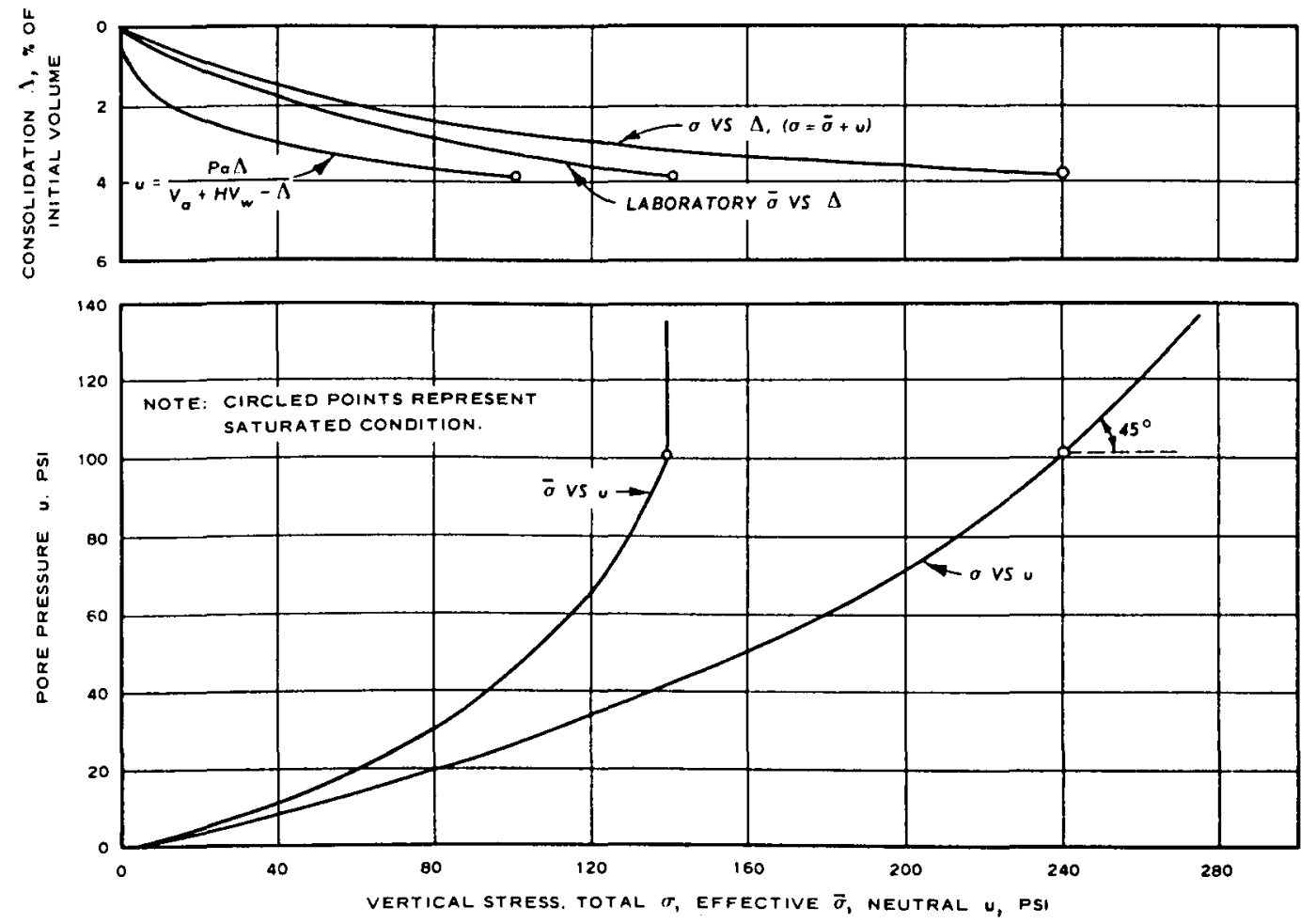

Fig. 1. Method of predicting construction pore pressures (Hilf ${ }^{25}$ )

unique for a given set of conditions. From these curves then, curves for total stress $(\sigma)$ versus consolidation, and subsequently curves of effective stress $(\bar{\sigma})$ versus pore pressure and total stress versus pore pressure were developed. The last curve ( $\sigma$ versus $u$ ) is used to estimate field pore pressures (see fig. 1). With the assumption that $\sigma$ is equal to the weight of overlying fill, entering the curve $\sigma$ versus $u$ with the appropriate fill weight gives a corresponding value for the pore pressure. To facilitate finding the $\sigma$ versus $u$ curve, Hilf developed nomographs which would (a) solve for $V_{a}$ and $H V V_{W}$ from the placement characteristics and (b) solve equations 1 and 2 for a desired amount of consolidation.

9. In questioning the reliability of the method, Hilf noted that the consolidation test with its conditions of complete lateral restraint might not be reproduced in the field. However, he concluded from field data that this condition was approximated in the central regions of the dam core. Because sufficient laboratory data were not available, Hilf was not able to arrive at $\sigma$ versus $u$ curves for comparison with piezometer readings in 
USBR dams, but utilizing available field and laboratory data, he approximated the $\sigma$ versus $u$ curves for Green Mountain and Anderson Ranch Dams. Comparisons of these curves with piezometer readings plotted versus overburden pressure indicated that the curves yielded reasonable estimates of pore pressures.

10. Although the assumptions used in the development of Hilf's method limit its applicability, the method eliminated objectionable complex mathematical difficulties encountered in use of the method developed by Bruggeman et al. Criticism of the method has come from Hilf ${ }^{26}$ himself who realized the weakness of assuming no surface tension. Additionally, the assumption of no drainage is often overconservative, particularly where internal drainage is provided. This drawback has been overcome by Li, 29 who used Hilf's method but compensated for pore pressure dissipation during construction. Although it can be justifiably argued that the overburden pressure does not represent the vertical principal stress, Bishop ${ }^{6}$ has shown that as long as the slopes of the dam are not too steep, this assumption serves as a good approximation. Despite the drawbacks of Hilf's method, it often enables a reasonable estimate of construction pore pressures to be made with data which are readily obtained from routine consolidation and compaction tests.

\section{$\underline{\text { Rufenacht (1948) }}$}

11. In his approach, Rufenacht ${ }^{35}$ evaluated pore pressures due to consolidation of a dam by use of an expression derived by 0 . K. Frölich. 45 Frölich applied Terzaghi's consolidation theory to the consolidation of a clay layer in the process of sedimentation and established an expression for the pore pressure at the bottom of the consolidating layer. Rufenacht proposed that the sedimentation and resulting consolidation of a clay layer were analogous to the placement of fill at an even rate and its resulting consolidation. Three further assumptions were required to allow computation of pore pressures in an earth dam by Frölich's expression: (a) the rate of construction is represented by the velocity of sedimentation, (b) the consolidation theory can be extended to unsaturated materials, and 
(c) drainage occurs in a vertically upward direction only, irrespective of the shape of the structure. Pore pressures at depths other than the bottom of the clay layer were computed from the assumption that the isochrones were parabolas.

12. Rufenacht concluded that his assumptions led to pore pressure values which were on the conservative side, so much so that if they seemed excessive, "a reduction could be effected by judgment, taking the shape of the structure into consideration, particularly as regards possibilities of lateral drainage." Of these additional assumptions, Rufenacht stated that only the first would not introduce further error into the estimation of pore pressure by Frölich's theory. Also it could be noted that the assumption of parabolic isochrones would apply only if the foundation of the dam were less pervious than the core of the dam, since otherwise drainage would occur at the boundary between the core and the foundation. These and other criticisms have limited the use of Rufenacht's method.

\section{Skempton and Bishop (1954)}

13. In 1948, Skempton ${ }^{40}$ proposed a solution for determining the pore water pressure set up in a fully saturated soil expressed in terms of the major and minor principal stresses, assuming that the undrained soil behaved in accordance with elastic theory. To compensate for the discrepancy between elastic behavior and actual behavior of a soil, Skempton replaced the elastic constants in the expression by a factor found in a laboratory triaxial test, the commonly known "A" factor.

$$
\Delta \mathrm{u}=\Delta \sigma_{3}+\mathrm{A}\left(\Delta \sigma_{1}-\Delta \sigma_{3}\right)
$$

Through development by Skempton and his contemporaries, $6,12,24$ a practical pore pressure theory for use in predicting embankment pore pressure during construction was published in two articles authored, respectively, by Skempton and Bishop in 1954. 41,7

14. Skempton ${ }^{41}$ extended his expression for pore water pressure in saturated soils to unsaturated soils where 


$$
\Delta u=B\left[\Delta \sigma_{3}+A\left(\Delta \sigma_{1}-\Delta \sigma_{3}\right)\right]
$$

and $B$ is another experimentally determined factor. The $B$ factor was found to range from $O$ for completely dry soils to 1 for completely saturated soils. For any given soil, the coefficient A was found to vary with stresses and strains. Bishop ${ }^{7}$ rearranged Skempton's expression for more convenient handling as follows:

$$
\frac{\Delta \mathrm{u}}{\Delta \sigma_{1}}=\overline{\mathrm{B}}=\mathrm{B}\left[1-(1-\mathrm{A})\left(1-\frac{\Delta \sigma_{3}}{\Delta \sigma_{1}}\right)\right]
$$

The use of equation 5 involves the assumption of no dissipation of pore pressures, since excess pore pressure is a function of applied stress only. Bishop believed the form of equation 5 to be particularly useful since the only stress required to calculate the pore pressure could be approximated by the overburden pressure. Unfortunately, the factor $\bar{B}$ was found not to be constant, but rather to be subject to variation with the principal stress ratio $\Delta \sigma_{3} / \Delta \sigma_{1}$. Thus, Bishop suggested that for an accurate determination of the factor $\overline{\mathrm{B}}$ for a given problem, a testing procedure should be used in which the principal stresses in the tests approximate the actual soil stress during construction of the dam.

15. Bishop noted in an article in $1957^{9}$ that use of the method in the form described herein resulted in overconservative results if allowances were not made for drainage in dams with internal drainage provisions which caused pore pressure dissipation. Another important difficulty encountered in the use of the method is caused by the $\bar{B}$ factor. $\bar{B}$ depends on both the $A$ and $B$ factors, both of which vary with the magnitude of the stress. But if $\bar{B}$ is evaluated properly and drainage is absent, the method presented by Bishop can provide reasonable estimates of the pore water pressure. Several references were given by Bishop which illustrated the proper application of the method to practical problems and served to substantiate the validity of the method. $7,21,42$

\section{Bishop (1957)}

16. The assumption of no drainage throughout construction of a dam 
has been shown by Hilf $\mathrm{H}^{25}$ to be valid for the central portion of the dam core in the case of USBR dams. However, in the case of Usk Dam, a dam compacted wet of optimum with numerous drainage blankets in the core, Bishop ${ }^{8}$ found the assumption to be overconservative and pointed out that pore pressure dissipation during construction shutdown resulted in a twofold effect on the value of excess pore pressure at the end of construction. The first and most obvious effect is that of relief of pore pressure by dissipation. The second effect occurs most significantly when soils are compacted wet of optimum. After a period of dissipation of pore pressure, the increase of pore water pressure with increasing stress was found to be less than the increase before dissipation, thus the twofold effect.

17. To provide a solution for such cases, Bishop ${ }^{9}$ used an approach similar to that previously described by Hilf, 25 but Bishop allowed for the twofold dissipation effect encountered after construction shutdown. Assuming no drainage during active construction, the pore pressures were estimated in the following manner:

a. A $\bar{\sigma}$ versus $\Delta$ relation was established from either a drained triaxial test or an undrained test with measured pore pressures.

b. A $u$ versus $\Delta$ relation was established by an expression found using Boyle's law and Henry's law, assuming surface tension to be negligible.

c. From these two curves, a u versus $\sigma$ curve was established and pore pressures up to the point of construction shutdown were estimated (fig. 2).

During a construction shutdown, dissipation of pore pressure occurs, compressibility of the soil decreases, and effective stress increases. This process is represented in fig. 2 by progressing from point la to $1 \mathrm{~b}$. The total stress is constant during the shutdown; thus, the effective stress increases by an amount equal to the drop in pore pressure, and the volume change increases to $\Delta_{\mathrm{b}}$. With a new value of the pore pressure at the beginning of active construction in the second stage, a new degree of saturation and porosity was figured, thereby allowing a new relation between $u$ and $\Delta$ to be calculated. As can be seen in fig. 2 , the process described above for a condition of no drainage during active construction is repeated for stage 2 construction. The results of a set of typical calculations are shown in fig. 3. 

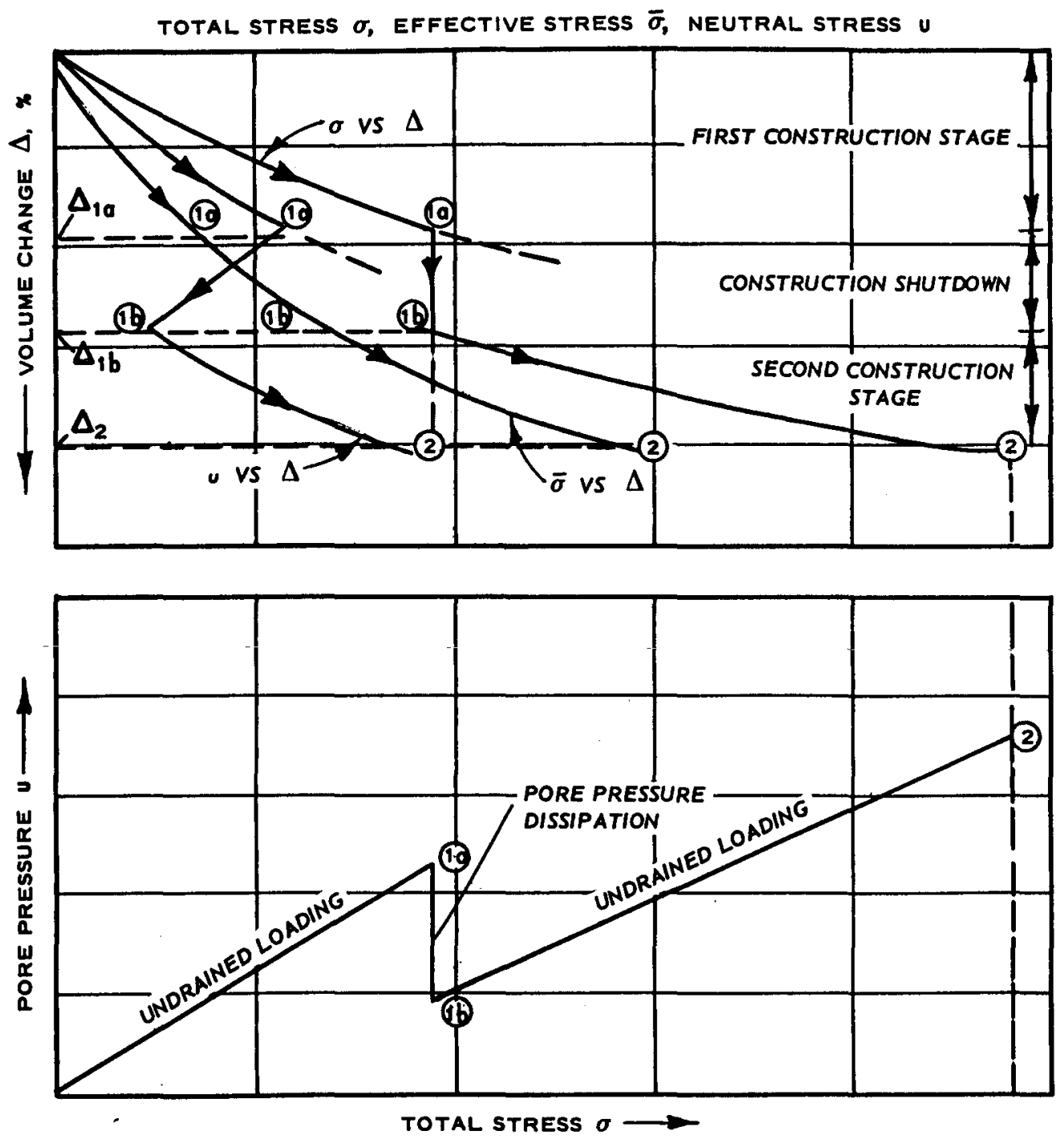

Fig. 2. Relation between pore pressure and total stress for the case of partial dissipation of pore pressure (Bishop9) 
MAJOR EFFECTIVE PRINCIPAL STRESS $\bar{\sigma}$, PSI
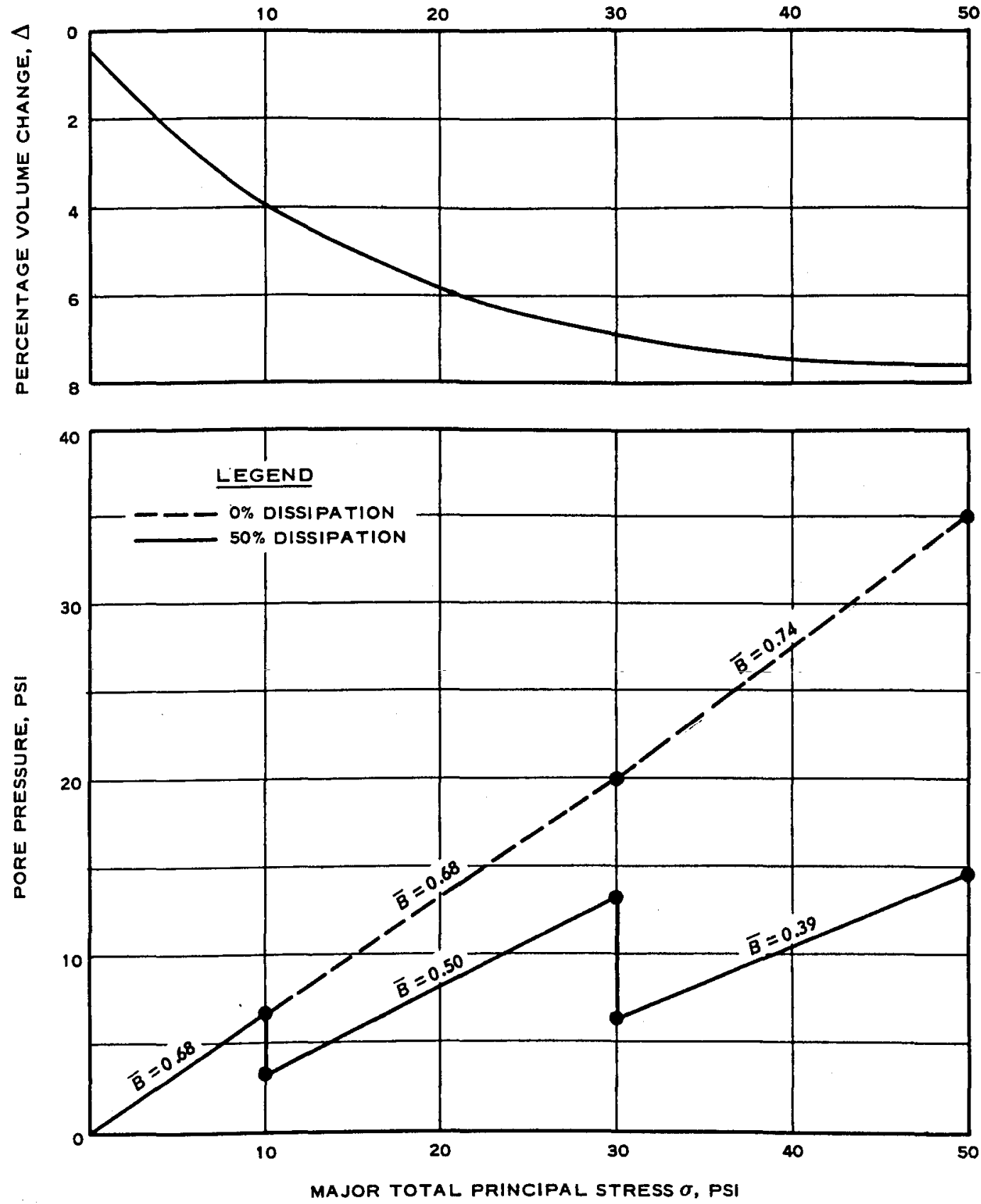

Fig. 3. Results of a typical set of calculations with 50 percent dissipation of pore pressure between each loading stage compared with zero dissipation (Bishop') 
18. As is noted by Bishop, the results of this method can be upset by the changing state of shear in the dam, which is an indeterminate problem at the present. Additionally, the method can give somewhat conservative results if dissipation continues during active construction. This effect, as will be shown, has been noted in a number of CE dams. However, in providing for compensation for the twofold effect of pore pressure dissipation during shutdowns, Bishop added to the accuracy of his method. The method has been used for a number of dams having difficult design problems and has provided reasonable estimates of the construction pore pressures.

\section{Bernell and Nilsson (1957)}

19. Bernell and Nilsson ${ }^{4}$ developed electrical analogy equipment for the study of nonstationary, two-dimensional flow problems in earth dams for the Swedish State Power Board. The equipment permitted analysis of construction pore pressures at any time during the construction of the dam. Though not completely described by Bernell and Nilsson, the equipment is described as consisting of 400 capacitors inserted in an electrical resistance network with special voltmeters for measuring the charge of the capacitors. The process of consolidation, which may take several years in earth embankments, is reproduced in less than 1 sec and can be stopped for a study of the process step by step. With the equipment, the pore pressure $u$ at a time $t$ can be determined by the following equation for twodimensional consolidation:

$$
\frac{\partial u}{\partial t}=C_{v}\left(\frac{\partial^{2} u}{\partial x^{2}}+\frac{\partial^{2} u}{\partial y^{2}}\right)
$$

where $\mathrm{C}_{\mathrm{V}}$ is the coefficient of consolidation whose value is obtained from a triaxial consolidation test.

20. From the illustrations presented by Bernell and Nilsson, it appears that difficult boundary conditions can be adequately reproduced in the equipment. This model analogy approach to the problem of pore pressures under nonstationary conditions is less difficult than the complex mathematical approach which has negated the value of some earlier methods. 
In the Scandinavian countries many dams are built by the wet-fill technique because of prevailing field conditions. In this method the fill is placed at near-saturation conditions; the Bernell and Nilsson method is particularly applicable to this condition, since use of equation 6 assumes saturation.

\section{$\underline{\operatorname{Li}(1959)}$}

21. Upon analysis of pore pressure data from the construction of Quebradona Dam, Colombia, South America, $\mathrm{Li}^{29}$ concluded that a method for predicting pore pressures should allow for dissipation of pore pressure during active construction. Comparison of observed data with the predicted values based on the assumption of no drainage revealed that the predicted values were far too high. Ii also noted that the rate of increase of pore pressure decreased with the total loading and ascribed this to the same twofold effect of pore pressure dissipation analyzed by Bishop ${ }^{9}$ for cases of construction shutdown. The general approach chosen by $\mathrm{Li}$ is outlined as follows (f'ig. 4).

a. Obtain a $\bar{\sigma}$ versus $\triangle$ relation from the consolidation test.

b. For an arbitrarily assumed increment of $\bar{\sigma}$, a $\Delta$ is chosen and used to calculate a corresponding value of $u$ using the equation expressed by Hilf for a condition of no drainage (equation 1). This point is denoted la in fig. 4.

c. An assumed value of dissipation is chosen, in this case $1 / 3 \mathrm{u}$, and added to the $\bar{\sigma}_{1}$ value, yielding the $\Delta$ at which the initial pore pressure for the next loading will be found. This change is illustrated in the tabulation in fig. 4 by step $1 b$. The pore pressure is now at point $1 b$.

d. Assuming the degree of saturation remains unchanged, the new conditions for use in Hilf's expression are calculated by an expression derived by Li.

e. The process from steps $l a$ to $l b$ is repeated until the maximum value is reached that is useful in design. A curve is drawn through points $1 \mathrm{~b}, 2 \mathrm{~b}$, etc., representing the actual $u$ versus $\Delta$ curve for the core of the dam.

f. A $\sigma$ versus $\Delta$ curve is plotted from the new $u$ versus $\Delta$ curve and the $\bar{\sigma}$ versus $\Delta$ curve.

Actual values of $u$ versus $\Delta$ from Quebradona Dam are shown and compared 


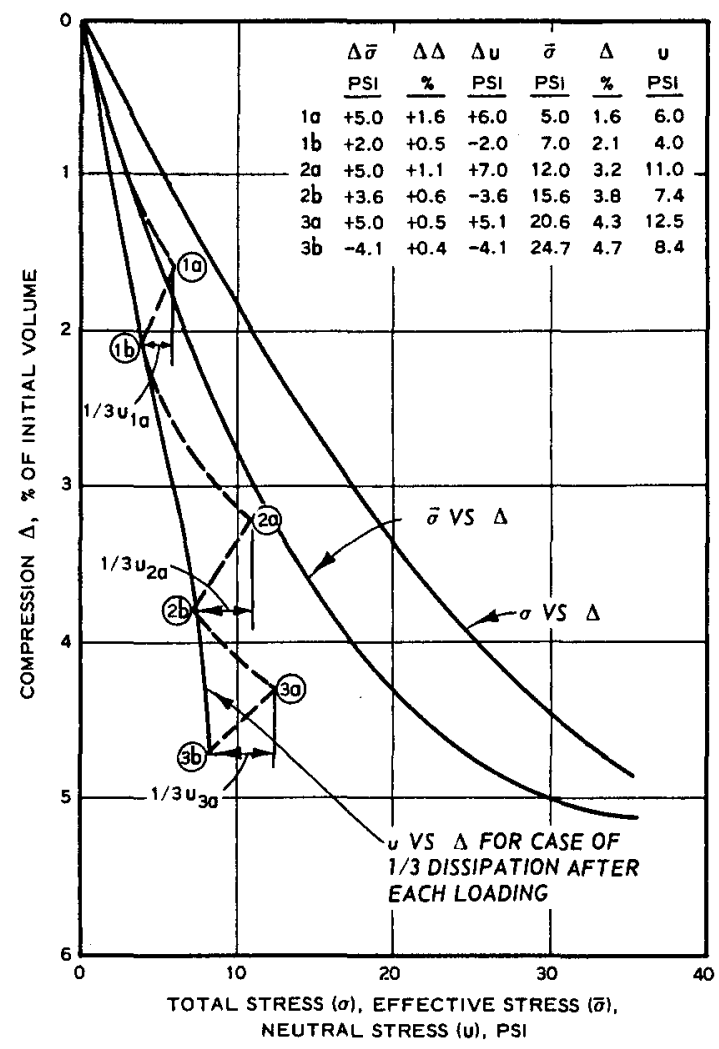

Fig. 4. Derivation of pore pressure and total stress versus compression relation for case of one-third dissipation ( $\mathrm{Li}^{29}$ )

Fig. 5. Comparison of actual and computed pore pressures ( Li29)

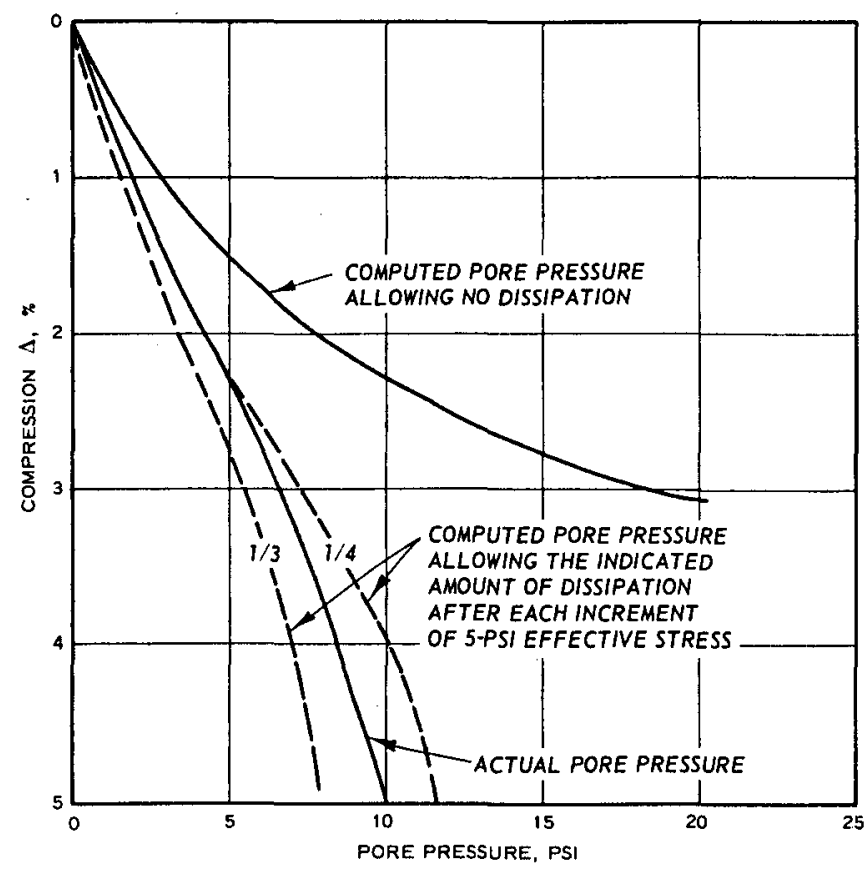


with the theoretical values for various degrees of dissipation in fig. 5 .

22. Li points out that the defect in his method is the assumption of a percentage pore pressure dissipation, which must be made on the basis of "engineering judgment." The method also can be no better than the accuracy allowed by the use of Hilf's solution for construction pore pressures. The real significance of Li's method is that even though a conservative value of dissipation is chosen, the resulting estimated pore pressures would be closer to reality than assuming no drainage at all.

\section{Other References}

23. In the literature review, certain references presented information pertinent to the problem of estimating construction pore pressures in earth embankments although this information did not necessarily deal with the problem per se. These references are summarized chronologically in the following paragraphs.

Daehn and Hilf (1951)

24. Daehn ${ }^{16}$ recommended that pore pressures be accounted for in the stability analyses of earth dams and that measuring devices be installed in the embankment for observing pore pressures and settlement during and after embankment construction. Data obtained from these measuring devices can be used to determine the performance of the dam during and after construction, and to provide information for the design of future dams. Factors to be considered in design are as follows:

$$
\begin{aligned}
& \text { a. Climatic conditions } \\
& \text { b. Length of construction season } \\
& \text { c. Placement water content } \\
& \text { d. Rate of embankment construction } \\
& \text { e. Types of compaction equipment }
\end{aligned}
$$

25. The practice of USBR of compacting earth embankments "dry of optimum" was discussed by Hilf. ${ }^{16}$ The basis for this practice was explained by consideration of shear strength and compaction. When a soil is compacted 1 to 3 percent dry of optimum water content, "it is possible to obtain a unit weight of soil that will ensure maintaining the angle of 
friction used in the design and at the same time preclude the development of a high pore pressure." 16 In order to obtain the unit weight of soil required above, it is the practice of the USBR to place the embankment at a field compaction effort which is higher than laboratory compaction effort. Gould (1954)

26. The compressibility of a soil is the one factor included in almost every method of estimating construction pore pressures. Gould 22 investigated the primary and postconstruction consolidation, with emphasis on the primary consolidation and its causes. The primary consolidation of a fill is important because of its influence on pore pressures developed during construction. To study primary compression, compression curves of observed strain versus effective stress were derived for 33 impervious materials from 22 USBR earth dams. In order to obtain the consolidating stress, the weight of the overburden material was assumed to represent the total stress at a point, from which the observed pore pressure was subtracted to obtain the effective consolidating stress. Soil type was found to have a significant influence on primary compressibility, with compressibility increasing from gravels and sands to clays of low to medium plasticity. Placement water content was noted to have a significant influence.

Materials placed wetter than about 0.5 percent below optimum exhibited compression curves convex upward in logarithmic plots with high initial strain and progressively decreasing compressibility. Those soils compacted drier than about 2 percent below optimum have concave curves with low initial strain and constant or slightly increasing compressibility, so that in some instances compressibility is maximum at the end of construction.

Two important sources of error in determining field curves are listed by Gould as "(a) inaccuracies in the estimate of total vertical stresses and (b) the contribution of shear deformation to observed vertical strain." Hilf (1956)

27. Hilf ${ }^{25}$ developed in 1948 a method for estimating construction pore pressures which included the assumption of a flat air-water interface. After a thorough study of available literature on surface tension, $\mathrm{Hilf}^{26}$ concluded in 1956 that such an assumption was unjustified in most soils 
and that the existence of surface tension caused the pressure in the soil water to be less than that in the air in the soil. In the development of the theory, Hilf showed that the radius of curvature of the meniscus was independent of the air pressure, thereby allowing the pore water pressure in a soil to be expressed as an algebraic sum of air pressure and capillary pressure:

$$
u=u_{a}+u_{c}
$$

where

$$
\begin{aligned}
& u=\text { pore water pressure } \\
& u_{a}=\text { final air pressure } \\
& u_{c}=\text { capillary pressure }
\end{aligned}
$$

Final air pressure is found by use of Boyle's law of compressibility of ideal gases and Henry's law of solubility of air in water. Capillary pressure, resulting from curvature of the menisci, either is measured in a laboratory test or is estimated. It is to be noted that the major assumption is that of no drainage, otherwise $u_{a}$ would be indeterminate. Hilf checked the validity of his theory by actual measurement of pore water pressure in a device similar to the ordinary triaxial compression apparatus. The pore pressure was measured in the sample by a "no flow" device with a porous probe which was inserted into the sample. Hilf concluded, "The results of the experiments made in this investigation indicate that the theory is in reasonable agreement with reality for the soils tested." Hilf believed that the theory led to a better understanding of the basic mechanical properties of cohesive embankment soils. Practical applications of $\mathrm{Hilf}^{\prime}$ s theory were directed to rapid water control, consolidation upon saturation, and economical design of high embankments.

Bernel1 (1957)

28. Weather conditions in Scandinavia require the employment of the wet-fill technique for earth dams, thereby necessitating thorough knowledge of the soil properties of the commonly used glacial moraines to ensure stable embankment sections. Bernell ${ }^{3}$ presented the results of an extensive testing program on these glacial moraines and discussed the effects of clay content and degree of saturation upon the development of pore pressures 
and shear strength. While a considerable difference was found in pore pressures developed under application of confining pressure for the clayey and silty moraines at a saturation of 80 percent, this difference is considerably diminished at saturation values commonly used in the wet-fill method, which range from 90 to 95 percent. Shear strengths were found to be similar for both soils, as were pore pressures developed during shear. LeMoigne (1957)

29. LeMoigne 28 presented a review of methods of determining pore pressures during construction, steady seepage, and drawdown. Comparisons and criticisms made by various authorities were quoted as to the value of each method. LeMoigne concluded that no method could give an answer any better than an estimate since a.l factors of influence were not taken into account in any of the presented solutions. It was also his opinion that "the danger of developing excessive pore pressures in a modern rolled fill dam has been somewhat overemphasized." The last chapters of LeMoigne's presentation are devoted to a review and critique of methods of pore pressure measurement both in the laboratory and in the field.

Bernell - (1958)

30. Using the electrical analogy equipment described by Bernell and Nilsson ${ }^{4}$ in 1957, Bernel. ${ }^{5}$ subsequently developed a series of pore pressure-time curves to show the effect of dimensions of the dam core on the dissipation of initial construction pore pressures. The hypothetical dam had an impervious core (with various side slopes) of material having a coefficient of consolidation equal to $0.1 \mathrm{~cm}^{2} / \mathrm{sec}$, surrounded by pervious fill with side slopes of 1 on 2 . The dam was founded on an impermeable base and had a height of $20 \mathrm{~m}$ with a crest width of $4 \mathrm{~m}$. The core was assigned side slopes of 10 on 1,5 on 1,2 on 1 , and 1 on 2 . Two cases were considered: (a) dam half completed, i.e. a fill height of $10 \mathrm{~m}$, and (b) dam completed to a height of $20 \mathrm{~m}$. As can be seen in figs. 6 and 7 , the initial pore pressure was assumed equal to 100 percent since this condition was often encountered in dam construction in Sweden with the wetfill technique. The important effect of core thickness can be seen in figs. 6 and 7. The time required for pore pressure dissipation for a core with slopes of 1 on 2 was 100 times that required for a core with slopes 


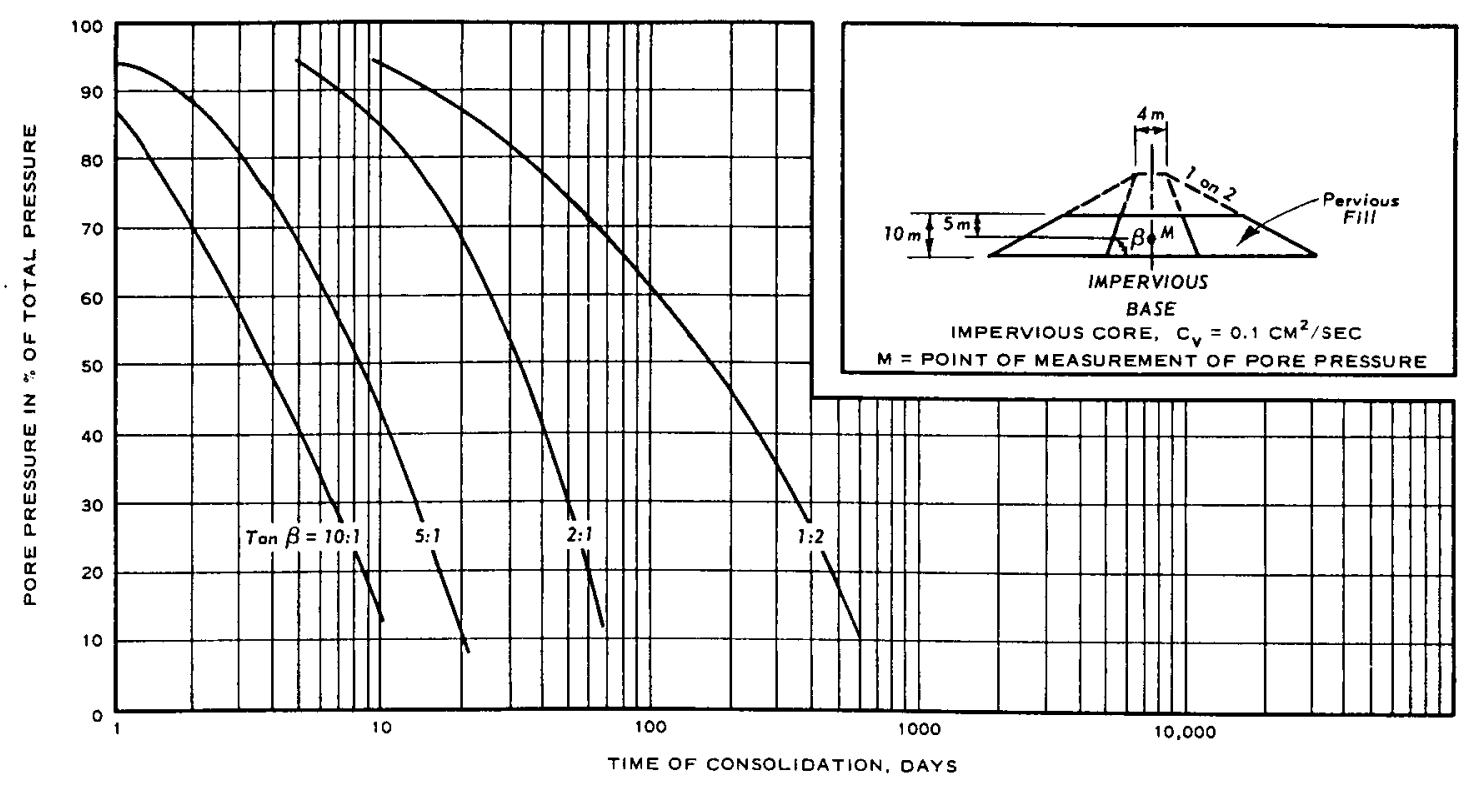

Fig. 6. Pore pressures in a wet compacted fill during consolidation. at constant load, $H=10 \mathrm{~m}$ (Bernel14)

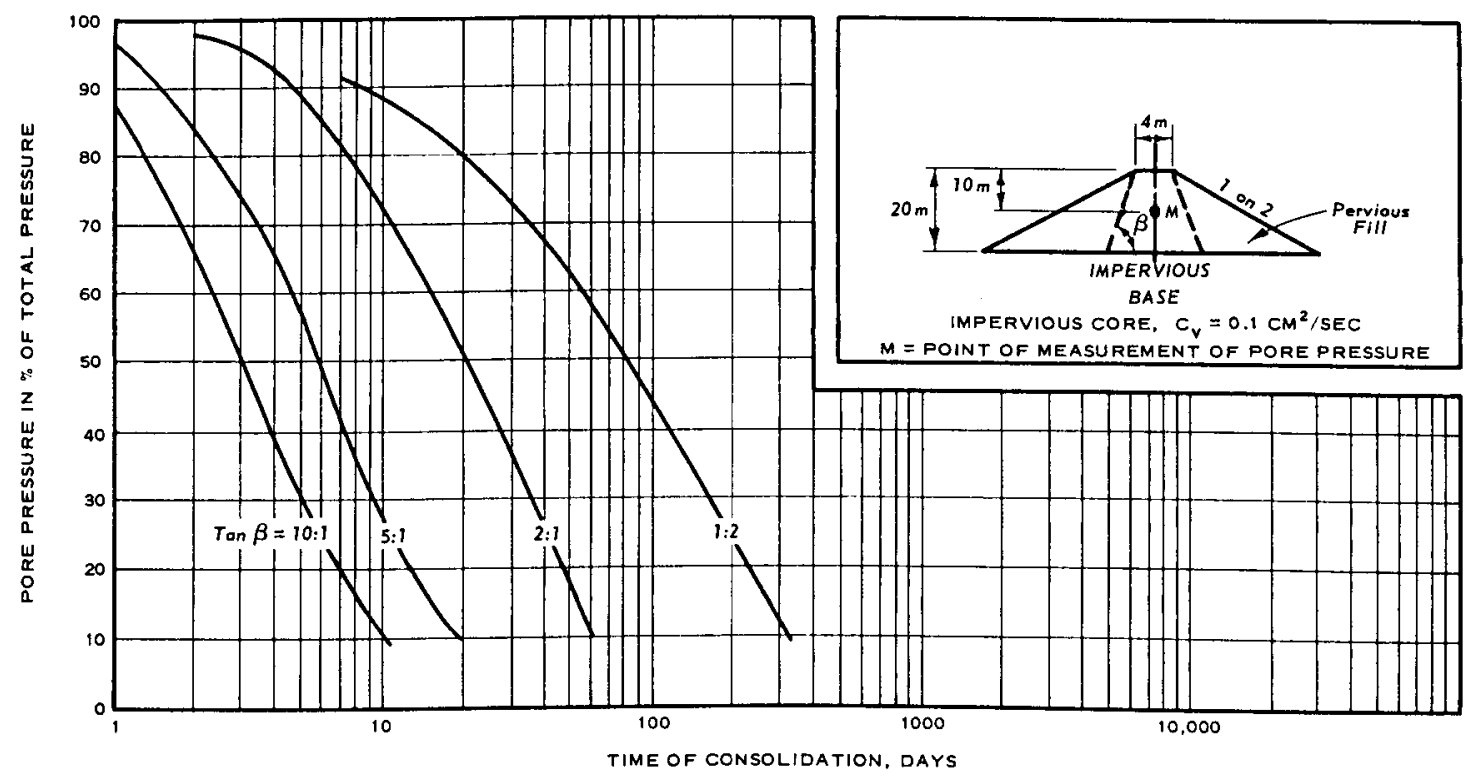

Fig. 7. Pore pressures in a wet compacted fill during consolidation at constant load, $\mathrm{H}=20 \mathrm{~m}\left(\right.$ Bernell $\left.{ }^{4}\right)$ 
of 10 on 1. According to Bernell, observations on two dams indicated that the finer the core material, the longer the period of dissipation. $\underline{\operatorname{scott}(1958)}$

31. In some instances, test embankments have been observed to assist in the design of an earth dam. Scott ${ }^{37}$ presented a summary of observations on an experimental clay embankment. The material contained in this embankment was to be used as the impermeable core of a rock-fill dam. One of the objectives of the investigation was stated as follows:

...observation of changes in shear strength, permeability, and cracking after placement, resulting from changes in moisture content and pore pressure. The factors causing such effects would be:

(a) Drying out or saturation spreading from the boundaries of the layer;

(b) Dissipation of excess pore pressures locked up in the mass during construction;

(c) Consolidation or swelling resulting from changes in intergranular stress caused by construction, reservoir filling, and settlement of the rockfill. 37

From the test embankment, scott found that pore pressure in the actual dam should be anticipated only in material compacted on the wet side of optimum. It was also to be anticipated that these pore pressures could be in the form of pockets of localized pore pressure where materials wetter than optimum were compacted within an area generally drier than optimum. Significantly, scott noted that forecasting the magnitude of pore pressures in the actual dam by use of the test embankment was not very successful. Gould (1959)

32. The USBR procedures used to predict construction pore pressures were evaluated by Gould. ${ }^{23}$ Case histories of 26 USBR dams were used to check calculated values of pore pressure with actual values obtained by piezometric observations. The theory used by Gould to calculate pore pressure values is that presented by $\mathrm{Hilf}^{25}$ in 1948 based on a combination of Hilf's own approach and that used by Brahtz ${ }^{13}$ in 1939. In Hilf's procedure, the laboratory consolidation test is used to find a relation between $\bar{\sigma}$ and $u$, but as such data were not available to Gould, he used the properties of the fill obtained from field density tests and internal vertical 
movement observations in the actual dam itself. After analysis of each of the 26 dams, Gould concluded that the maximum deviations from theory were caused by the deviation of reality from some of the basic assumptions and wide variations in average placement characteristics. The assumptions used in the theory were made unrealistic by (a) boundary drainage, (b) stress transfer, and (c) surface tension due to particles finer than a No. 200 sieve. Actual values were lower than the calculated ones because of drainage of the boundaries, since the simplified theory assumed no drainage. Stress transfer caused deviations in both directions of the calculated results. Since the overburden weight was assumed equal to the vertical stress at a given point, transfer of stress away from the point would result in an actual pore pressure less than that predicted, and transfer of stress to that point would result in a greater actual pore pressure. If the percentage of particles finer than the No. 200 sieve was significant, values of actual pore pressure would be less than the calculated values, since these small particles would cause the development of surface tension which would keep the actual pore pressure from reaching predicted values based on a theory in which surface tension was neglected.

33. After a thorough analysis and comparison of data, Gould concluded that "The evidence provided by embankment test apparatus generally substantiates the Bureau's theoretical analysis of construction pore pressures. "23

Alpan (1961)

34. As consolidation of an embankment occurs, the excess pore pressures are dissipated. Alpan ${ }^{1}$ noted that the amount of dissipation of excess pore pressure.is often predicted utilizing the relations between percentage of dissipation and the time factor found by the classical theory of consolidation, which assumes complete saturation of the soil. The time factor is expressed as:

$$
T=\frac{C_{v} t}{H^{2}}
$$

where

$$
T=\text { time factor }
$$




$$
\begin{aligned}
\mathrm{C}_{\mathrm{V}} & =\text { coefficient of consolidation } \\
\mathrm{t} & =\text { time } \\
\mathrm{H} & =\text { length of longest drainage path }
\end{aligned}
$$

To evaluate $\mathrm{C}_{\mathrm{v}}$, the laboratory time-compression curve (fig. 8) is compared with the theoretical function shown in fig. 9. The values of $T$ and $t$ at 50 percent consolidation obtained from figs. 8 and 9 are introduced into equation 8 along with the value of $\mathrm{H}$, and $\mathrm{C}_{\mathrm{v}}$ is obtained. For unsaturated soils, the $U$ versus $T$ plot by classical theory is not correct, and Alpan proposes a correction for this relation. In order to apply the correction derived by Alpan, the degree of saturation must be known at any time during the testing of a sample; this is determined by measuring volumes of air and water expelled from a specimen in a triaxial test. The correction $\rho$ is applied directly to the theoretical time factor,

$$
T(\text { modified })=\rho \times T(\text { saturated })
$$

and a modified $U$ versus $T$ curve is drawn and used to calculate a more correct value of $\mathrm{C}_{\mathrm{V}}$. Alpan's theory has particular application in the case of embankment consolidation during construction since, in embankment construction, the fill is placed in an unsaturated condition.

\section{Historical Trends}

35. From the historical review of various methods for estimating construction pore pressures, it is apparent that the concepts of the mechanism of pore pressure development during construction have undergone radical changes with time. Original assumptions have been continuously qualified so as to furnish a better analogy to actual field conditions. The factors which affect the magnitude of these construction pore pressures have been critically analyzed for over two decades, and knowledge of these factors has increased through observation of devices installed in many earth dams throughout the United States and the world. 


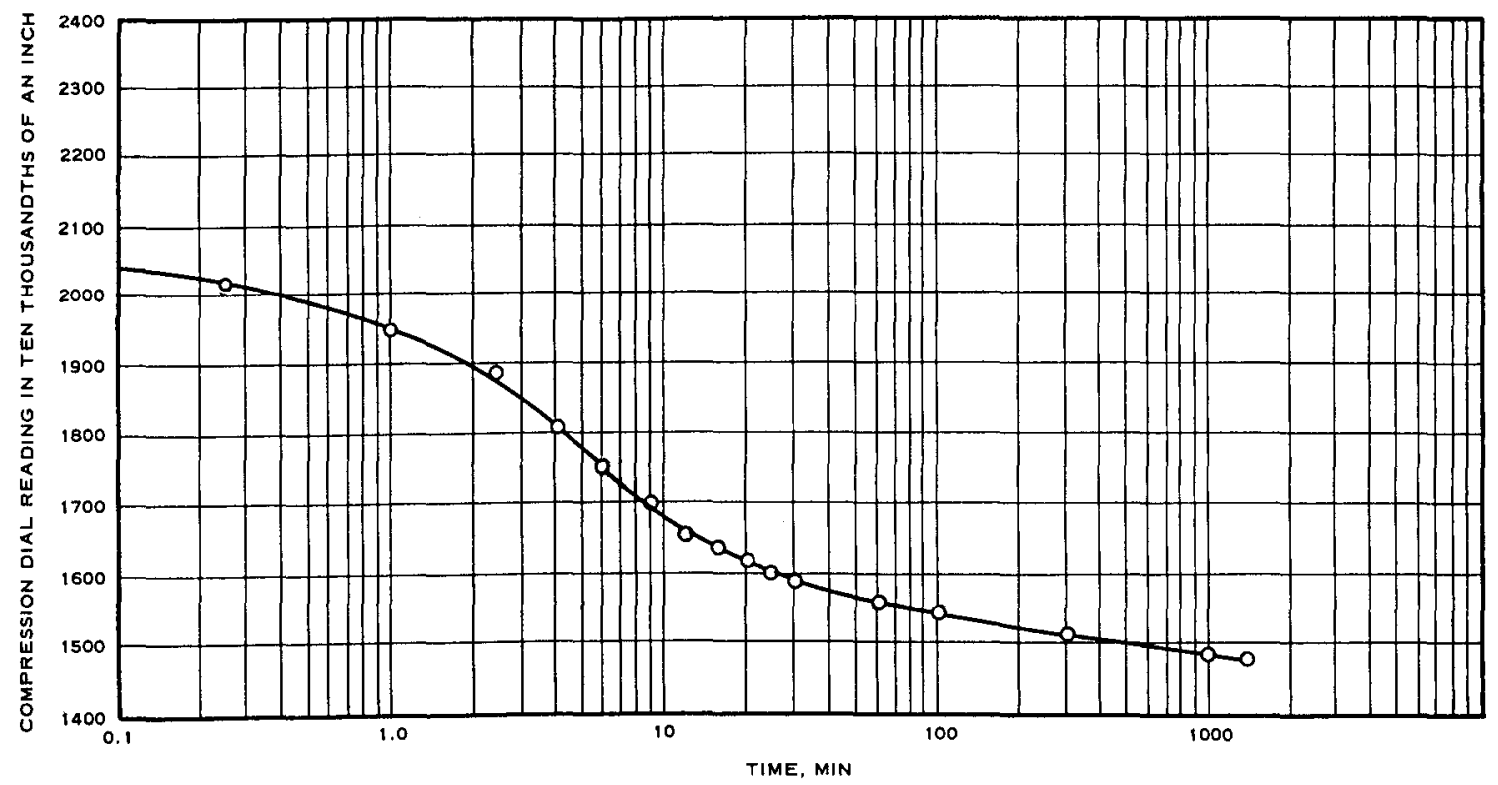

Fig. 8. Laboratory time-compression curve

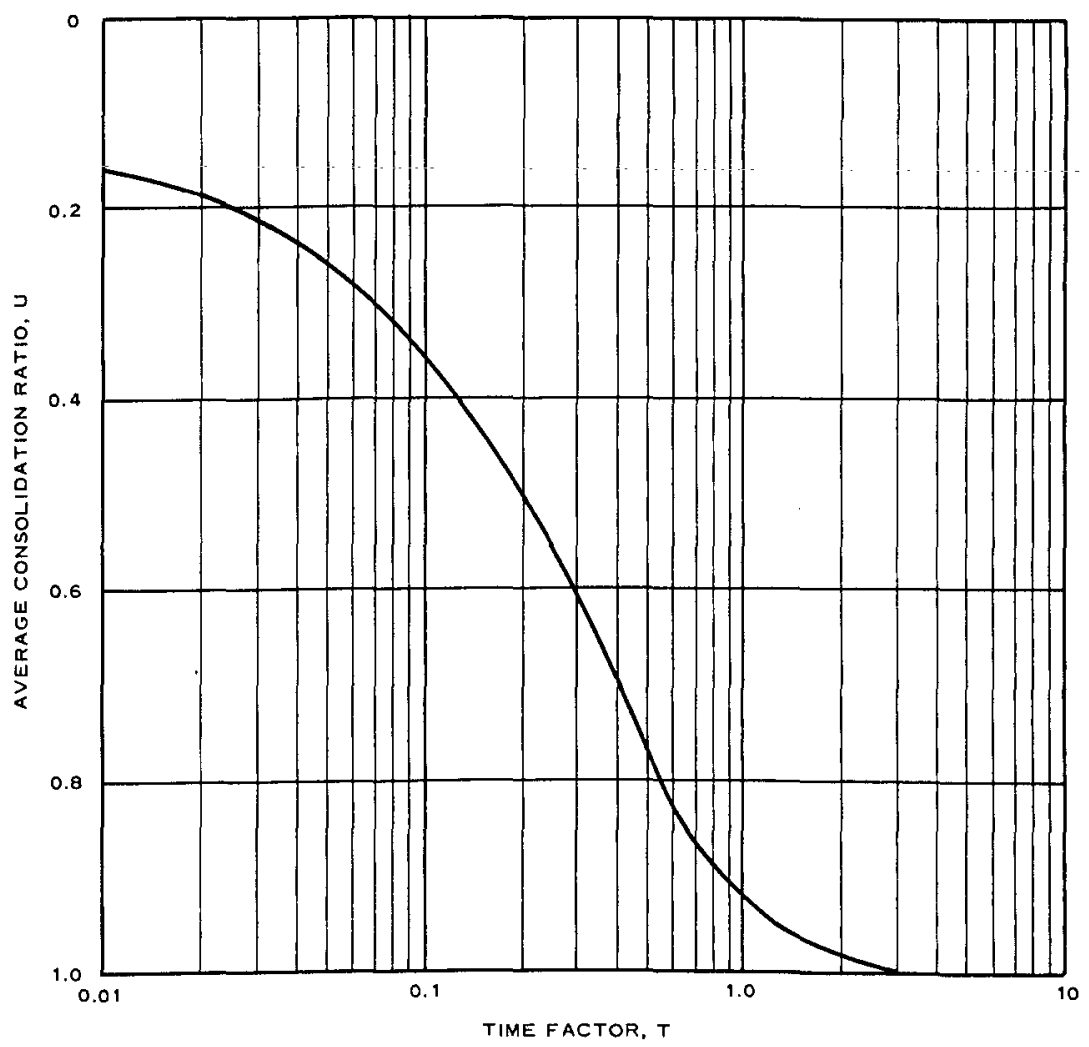

Fig. 9. Theoretical curve of consolidation ratio versus time factor for saturated soils 


\section{Sources of Data}

36. The source of the pore pressure data for each $\mathrm{CE}$ dam is shown in table Al, Appendix A. In addition, soils data and stability analyses for the various dams were obtained from design memoranda. The pore pressure data forwarded to WES for this study varied in extent and quality, thus more analysis is applied to some $\mathrm{CE}$ dams than others, depending on the amount of information available.

37. To supplement data from CE dams for particular portions of this study, additional sources of information were consulted. Published USBR reports provided the bulk of this additional information; these data provided a contrast in the effects of procedures, since the USBR dams were largely compacted on the dry side of optimum water content and the CE dams were generally compacted on the wet side of optimum water content. Embankment pore pressure observations for foreign dams were found in the technical literature. Materials and compaction procedures varied widely for the foreign dams, reflecting the large numbers of countries and research organizations represented.

38. Tables 1, 2, and 3 present the descriptive and observational data for each dam discussed in this report according to constructing agency, i.e. CE, USBR, and foreign agencies, respectively. Reference numbers for sources of data are shown in the tables.

\section{Pore Pressure Ratio}

- 39. The pore pressure ratio is defined as the pore pressure at a given point divided by the overburden pressure above that point $(\mathrm{u} / \mathrm{\gamma h})$. This ratio is used hereafter in this report because it is dimensionless and allows pore pressures to be compared between dams independent of their size.

40. Although the $\mathrm{u} / \mathrm{\gamma} \mathrm{h}$ ratio is sometimes found to be a maximum immediately after placement of material above a piezometer tip, the most critical value in regard to stability of the structure occurs at or near 
the completion of the dam when pore pressure is likely to be at its maximum. Thus, this value of the $u / \gamma h$ ratio is used for comparison with various factors which influence pore pressures.

41. In attempts to determine the effect of a specific factor on the maximum pore pressure at the end of construction, generally the average conditions were used for the entire fill in which the maximum occurred. But, if an author had noted a particular deviation from the average characteristics of the fill and expressed it in quantitative terms, an appropriate correction was applied to obtain a more realistic value.

\section{Piezometric Contours During and at the End of Construction of CE Dams}

42. Cross sections of the $\mathrm{CE}$ dams are shown in plates 1-10. Where sufficient information was provided, contours of piezometric head during construction and at the end of construction are shown in the sections. In other cases, only the piezometer readings in feet of water above the tip are shown.

Table Rock Dam

43. A cross section of Table Rock Dam showing contours of piezometric head at the end of construction is shown in plate 1 . The earth embankment of Table Rock Dam was constructed of relatively impervious lean clays (CL) with the central portion designed as a plastic zone. To achieve the plastic condition, the materials were to be placed at water contents between optimum and 2 percentage points wet of optimum as compared to the requirements that the water contents of the remainder of the impervious embankment material be between 2 percentage points wet or dry of optimum. Because of adverse weather conditions during construction and the use of wetter borrow materials than anticipated, the materials throughout the dam were placed on the wet side of the specified range. Computations based on table 1 and plate $I$ will demonstrate that piezometric levels were high enough to produce a pore pressure ratio of 60 percent at the end of construction in much of the lower portion of the embankment. Effective stress analyses of the stability of the upstream and downstream slopes yielded a minimum factor of safety of 1.03, emphasizing the significant influence of 
the construction pore pressures on embankment stability. It is also important to note here that although the maximum pore pressure ratio in the dam was not exceedingly high ( 62 percent at piezometer 12), the average pore pressure ratio was such that the factor of safety of the embankment was less than that assumed in design. In other words, high uplift pressures were exerted along most of the critical arc, producing a more significant effect than would a more localized higher pore pressure which might develop in a dam with a thin core. This factor must be kept in mind when discussing the danger of construction pore pressures.

44. From plate 1 it can be seen that although Table Rock Dam is practically symetrical in cross section, piezometer readings in the downstream zone indicate that the piezometric contours are sharply terminated near the drainage blanket since pore pressures were dissipated by drainage to the blanket in both horizontal and vertical directions. Note, also, that the rock foundation is apparently quite impervious; otherwise the piezometric contours would have been approximately oval shaped, reflecting drainage at that boundary.

Blakely Mountain Dam

45. Piezometric contours for various stages of construction of Blakely Mountain Dam are shown in plate 2. Although the materials for Blakely Mountain Dam were generally placed at water contents wet of optimum, negligible pore pressures were observed in much of the embankment. In the design of the dam, pore pressure ratios of 46 percent in the core section and zero in the coarse random fill section were assumed; as indicated in table 1 , the maximum pore pressure ratio observed was only 18 percent. This value was obtained from piezometer 14 and probably reflects the influence of seepage from the low reservoir shown in plate 2. This maximum value by no means is representative of the whole embankment since in the upper two-thirds of the embankment the pore pressure ratio is approximately zero. From soil characteristics data, dam geometry, and experience, the design assumption would seem to be a reasonable one, but the fact that the design assumption was overconservative illustrates the difficulty of estimating embankment pore pressures.

46. The drainage blanket in the downstream portion of the dam 
certainly served to dissipate pore pressures developed in its vicinity, whether due to construction or seepage. All piezometers slightly above the blanket indicate no excess pore pressures, and horizontal drainage to the blanket reduced pore pressures in the core as can be seen by the shape of the piezometric contours.

Otter Brook Dam

47. The cross section of Otter Brook Dam with selected piezometer readings at the end of construction is shown in plate 3 . Construction pore pressures in Otter Brook Dam were estimated by a modification of the method described by Hilf $f^{25}$ in 1948. The method used was as follows: (a) for given placement conditions, pore pressures were calculated by Hilf's method, assuming no drainage; (b) from laboratory consolidation tests, a rough estimate of the rate of drainage was made and the no-drainage pore pressures were then reduced by a factor equal to $I-U / 100$, where $U$ is the percent consolidation; and (c) curves of pore pressure versus total vertical stress were prepared for various points in the embankment and piezometric contours were drawn for the critical embankment section. Using these values of pore pressure in an effective stress stability analysis, the minimum computed factor of safety was 0.63 , but it was believed that this analysis was not realistic since an analysis using $\mathrm{S}-\mathrm{Q}$ soil strengths without using pore pressures gave a factor of safety of 1.33 for the same end-of-construction case. It is interesting to note that the actual values shown in plate 3 for piezometers $2-A$ and $2-B$ ( 134 and 61 ft of water, respectively) were not greatly different from those predicted for these locations (108 and $83 \mathrm{ft}$ of water, respectively).

Mad River Dam

48. Piezometric contours for two stages of construction of Mad River Dam are shown in plate 4. In the design of Mad River Dam, no assumptions were made regarding anticipated construction pore pressures. Stability of the embankment was analyzed using the shear strength obtained from $Q$ tests, which includes the assumption that the pore pressures set up in the test at failure represent those that will occur in the embankment if the full shear strength is mobilized. The maximum pore pressure ratio at the end of construction ( 40 percent) was calculated from piezometer 8 which is located 
in the random fill. Actually the maximum pore pressure ratio probably occurred within the impervious section at piezometer 6 since it indicated a higher pore pressure ratio than piezometer 8 during construction, but unfortunately piezometer 6 became inoperative as a result of freezing before completion of the dam. Lower pore pressures were indicated in the random fill than in the impervious fill, resulting in the parabolic shape of the piezometric contours. The assymetrical shape of the piezometric contours was caused by more rapid dissipation of pore pressures at the boundary of the chimney drain on the downstream side of the core. Although piezometer 5 is within the impervious core, it shows the lowest excess pore pressure of the four piezometers at that level due to its proximity to the chimney drain.

North Hartland Dam

49. The cross sections of North Hartland Dam for the first and final stages of construction, with corresponding piezometer readings, are shown in plate 5. In the design of North Hartland Dam, no estimations of construction pore pressures were made. As shown in plate 5, several piezometers were installed in the impervious fill of the dam. Although the maximum pore pressure was recorded at piezometer 9 on the dam axis, the maximum pore pressure ratio was reached at piezometer 11 (23 percent). Piezometers 1 and 3 showed substantial reductions in pore pressure from the first construction season to the end of construction. The magnitude of these reductions is questionable, since shortly after the end of construction the liquid in the piezometers froze, although some of the other piezometers provide some evidence of drainage to the internal drains shown in the sections.

Pomme de Terre Dam

50. The piezometer readings for Pomme de Terre Dam at the end of construction are shown in the cross section of the dam in plate 6 . This dam has a rather complex zonation. The impervious fill is surrounded by rock fill on one side and random earth fill on the other, with an internal chimney drain between the impervious and rock fill. Stability at the end of construction was analyzed using $\mathrm{S}$ shear strengths and an assumed pore pressure ratio of 33 percent in the impervious fill. The impervious 
fill was compacted on the wet side of optimum intentionally to develop flexibility in the core. Construction pore pressures in the embankment were measured only in the impervious fill. Piezometers 1, 2, and 3 in plate 6 show that pore pressures lessened considerably as the random fill zone was approached. Actual pore pressure ratios were higher in the impervious fill than assumed ( 51 percent at piezometer 1 and 59 percent at piezometer 2), but these higher ratios were probably reduced on the other side of the impervious core by drainage to the chimney drain. The assumption of 33 percent was not unrealistic when the average conditions in the core were considered.

\section{Hills Creek Dam}

51. Cross sections of Hills Creek Dam with piezometer readings from the core are shown in plate 7. This dam has a gravel-rock shell with a thin, centrally located impervious core. Relatively high values of pore pressure were recorded throughout the core despite the favorable drainage conditions. Average placement water content was 1.6 percent above optimum. Stability analyses were performed using $S$ shear strengths and values of pore pressure ratios along the failure arc in the core of $0,40,50,60$, and 100 percent for the end-of-construction case. The stabilizing effects of the gravel-rock shells were such that even with a pore pressure ratio in the core of 100 percent, the minimum factor of safety was 1.36. The actual calculated maximum pore pressure ratio occurred at piezometer 15 (52 percent), which represented little threat to the stability of the structure because of its localized occurrence.

\section{Dewey Dam}

52. Dewey Dam (plate 8) is essentially an unzoned embankment of impervious fill with a'relatively small downstream zone of random fill. According to the original design, the dam was intended to be constructed without internal drainage, but after first-stage construction, it was found that the fill had been compacted too wet, resulting in such a low shear strength that a stability analysis of the upstream slope of the proposed section yielded a factor of safety of only 0.47 . Further construction was then suspended. Piezometers installed to observe the excess pore pressure revealed that almost 100 percent of the overburden weight was 
being carried by the pore water. Remedial measures were taken before construction was resumed. Additional piezometers were installed to check pore pressures, and 1016 sand drains, 12 to 14 in. in diameter, were placed in the dam to allow dissipation of excess pore pressures (plate 8). After a delay of about $1 \mathrm{yr}$, construction was resumed. Pore pressures showed some tendency to increase as filling proceeded, but they were rapidly dissipated by drainage. The maximum pore pressure ratio (27 percent) occurred at piezometer 6 (plate 8 ), and an effective stress stability analysis indicated a factor of safety of 2.0 .

Texarkana Dam

53. Piezometer readings for Texarkana Dam at the end of construction are shown in plate 9. This dam is symmetrical with a thin impervious core surrounded by random fill. The random fill was largely a clayey sand (SC) which was approximately 100 times as pervious as the fat clay (cH) material placed in the core. No construction pore pressures were recorded in either the random fill or the impervious core during or at the end of construction. Design assumptions of construction pore pressures for the stability analyses were that the pore pressure ratio would be 40 percent except (a) at the toe of the failure arc where pore pressure was assumed to be zero, and (b) within $20 \mathrm{ft}$ of the ground surface where pore pressure was assumed to be zero.

\section{Ferrell's Bridge Dam}

54. As shown in plate 10, Ferrell's Bridge Dam has a sloping upstream impervious zone and is $77 \mathrm{ft}$ high along the valley floor. After the soil characteristics and observations of pore pressure on other projects were considered, it was decided to use a pore pressure ratio of 12.5 percent in the embankment fill in analyzing the stability of the embankment for the end-of-construction condition. It was also assumed that no pore pressures would be developed within $20 \mathrm{ft}$ of the surface. Observations of the piezometers throughout construction indicated that no excess pore pressures were developed at any time, substantiating the design assumption of low pore pressures. It is likely that localized pockets of pore pressure developed, since the average placement water content was above optimum, but they were probably rapidly dissipated and were never 
measured. At any rate, such pore pressures would not seriously affect the stability of the embankment.

\section{Pore Pressure Versus Overburden Pressure}

Background

55. Bishop 9 has shown that if dissipation of pore pressures occurs during delays resulting from construction stoppage, the rate of increase in pore pressure with subsequent increases in overburden pressure is lessened. This was a particularly important consideration in the case of dams recently designed by Bishop and his associates, since extensive internal drainage was employed to offset the detrimental effects of a high placement water content, and dissipation of pore pressures was to be anticipated. A hypothetical representation of these conditions is shown in fig. 10.

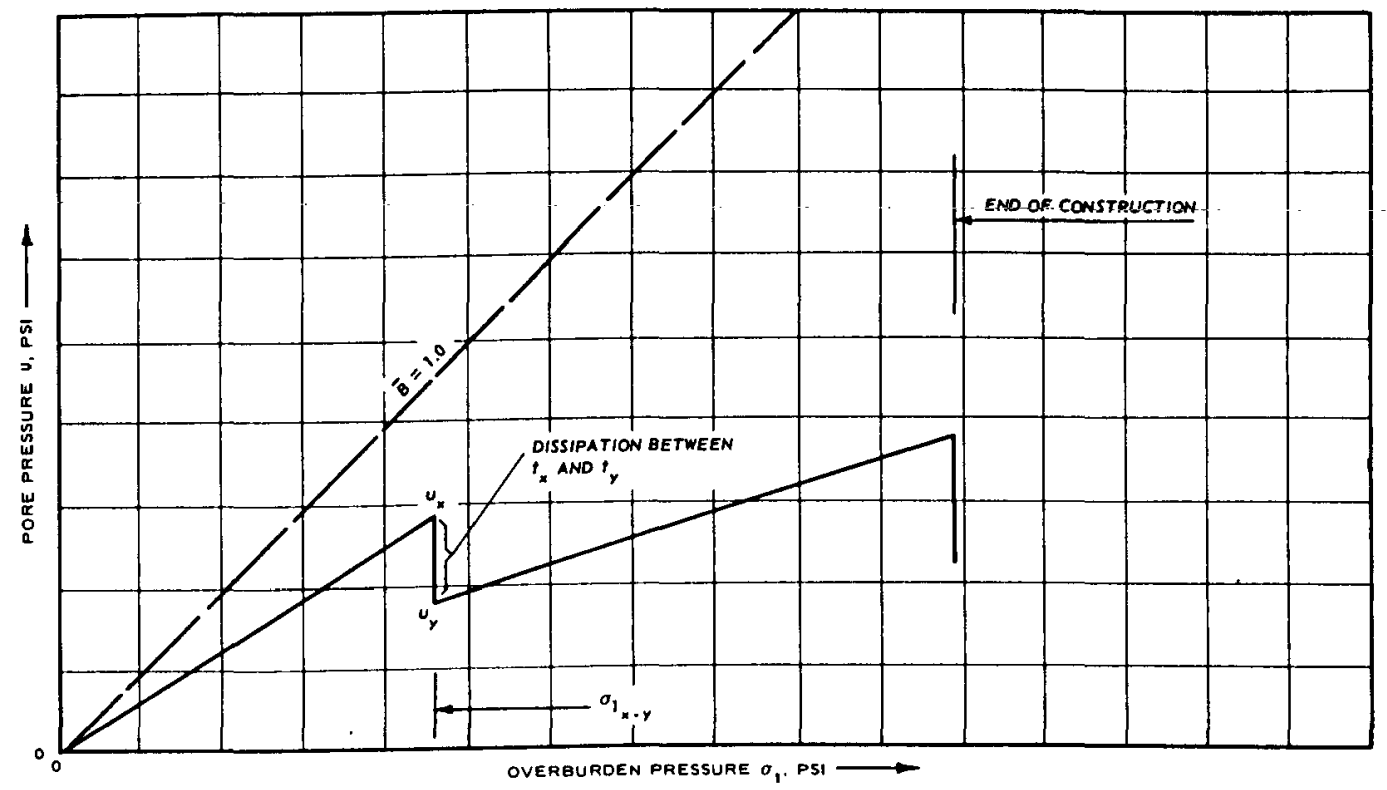

Fig. 10. Hypothetical representation of Bishop's hypothesis (Bishop ${ }^{9}$ ) Comparisons with actual data

56. To aid in determining when this pore pressure dissipation might be expected and to demonstrate its effect on rate of increase in pore pressures with subsequent addition of fill height, data are presented from 
four USBR dams and four CE dams in the form of $u$ versus $\sigma_{1}$ plots for selected piezometers from these dams (plates 11-18). The value $\sigma_{1}$ is assumed to be equal to the weight of the overlying fill. The piezometers selected generally reflected trends from all the piezometric data for a given dam and were chosen simply because they illustrated the point in question with more clarity than others. The average $\bar{B}$ values $\left(\frac{\Delta u}{\Delta \sigma_{1}}\right)$, piezometer locations, and proximity of drainage surfaces are given in table 4.

57. USBR dams. Plots of $u$ versus $\sigma_{1}$ for selected piezometers of the four USBR dams are shown in plates 11-15. Each of these dams has a large impervious central core without any central drains to provide relief of pore pressures. The plot of $u$ versus $\sigma_{1}$ for the piezometers of Anderson Ranch Dam (plate 1l) shows that pore pressures in this dam increased during construction stoppages. Gould ${ }^{23}$ attributes this to a transfer of stress from the central portion of the dam to the outer slopes, which is likewise indicated by the plots for Granby and Green Mountain Dams. It is significant that following the period of work stoppage during which little if any consolidation occurred, the $\bar{B}$ values for both Anderson Ranch and Green Mountain Dams remained approximately at their original values. Such a situation was depicted by Bishop ${ }^{9}$ in fig. 3 (see page 11) for the case of no dissipation of pore pressures during construction. Available pore pressure versus overburden pressure data for Vallecito Dam (plate 14) were given for only one construction season. The relation between $u$ and $\sigma$ would appear to be a constant for Vallecito Dam, again substantiating the assumption of no drainage for the central portion of the core of a dam.

58. The plot of $\sigma_{1}$ versus $u$ for piezometer 16 in the Anderson Ranch Dam (plate 11) indicated dissipation of pore pressures during the third construction season; it appears that some relief of pore pressure occurred due either to localized migration to a region of lower pore pressure or drainage to the granular shell. Examination of all additional available $u$ versus $\sigma_{1}$ plots in USBR Technical Manual $650^{23}$ for the piezometers in these four dams suggests that no drainage occurred in these dams except possibly late in the final construction period. 
59. $\mathrm{CE}$ dams. Data on the four $\mathrm{CE}$ dams are analyzed in the following paragraphs. Otter Brook, Mad River, and North Hartland Dams have large impervious fill sections drained by chimney drains of pervious fill. Cross sections of these dams are shown in plates 3-5. In contrast to the USBR dams, these three dams demonstrated the effect of consolidation during active construction by developing progressively lower $\bar{B}$ values throughout construction (plates 15-17). The generally higher initial $\bar{B}$ values for the CE dams probably stem from the fact that the $\mathrm{CE}$ dams were all compacted on the wet side of optimum, whereas all the USBR dams except Vallecito Dam were compacted ary of optimum.

60. The twofold effect of dissipation of pore pressures during construction stoppage can be clearly seen in plate 17, the plot of $u$ versus $\sigma_{1}$ for North Hartland Dam. This dam was not constructed in one season, and during the layoff, pore pressure relief was provided by the internal drain in the impervious fill. After construction was resumed, $\bar{B}$ dropped to a value of only 21 percent of the original $\bar{B}$. During the latter part of the last construction season, $\bar{B}$ aropped to 3 percent of the first construction season value. Thus, in addition to the relief of pore pressure during the layoff, the $\bar{B}$ value was considerably reduced.

61. Values of $\bar{B}$ for Hills Creek Dam (plate 18) reflect the effects of both dissipation of pore pressure and variation of rate of construction. In contrast to the other CE dams, Hills Creek Dam has no internal drain, but instead has a thin central core bordered on either side by pervious gravel shells (plate 7). The gravel shells provide for effective pore pressure relief in the thin core section. Thus, it might be anticipated that the $\bar{B}$ value would follow the trend of progressively smaller values throughout construction. In all the USBR and CE dams previously discussed, the rates of construction throughout the construction periods were approximately the same, but this was not the case with Hills Creek Dam. Initial fill placement above piezometer $I$ was at a rate of $1.09 \mathrm{ft}$ of fill per day and the corresponding $\bar{B}$ value was 0.72 . When fill placement dropped to $0.4 \mathrm{ft}$ per day, $\overline{\mathrm{B}}$ value dropped to 0.12 . Following the seasonal cessation of fill placement with consequent pore pressure dissipation, the $\bar{B}$ value dropped to 0.02 . The rate of fill placement when resumed was about $0.4 \mathrm{ft}$ 
per day as before the layoff, but as the embankment neared completion, the rate of placement was suddenly increased to $0.9 \mathrm{ft}$ of fill per day and the corresponding $\bar{B}$ value increased to 0.84 . This increase in fill placement in topping out an embankment often occurs in earth dam building, since in the last stages of construction very little material needs to be added to accomplish a rapid rise of the embankment.

\section{Factors Influencing the Magnitude of the Pore Pressure Ratio at the End of Construction}

62. The difficulty encountered in any method of predicting construction pore pressures is that all of the variables which have an influence on these pore pressures cannot be incorporated into the method. There is also the problem of evaluating the appropriate degree or magnitude of influence of a given factor. The following paragraphs present an evaluation of the various factors considered to have an influence on the magnitude of construction pore pressures and the maximum pore pressure ratio at or near the end of construction. Plate 19 shows the locations of the points of maximum pore pressure ratio for the $\mathrm{CE}$ dams listed in table 1 . It can be seen that the locations of the points of maximum pore pressure ratio vary as greatly between dams as do the numerical values of the ratios themselves.

Placement water content

63. Sherard et al 39 concluded that "the water content at which the embankment is constructed has the largest influence on the magnitude of the pore pressures which develop." This investigation in general has borne out this conclusion. Fig. 11 is a plot of placement water content expressed as a percentage difference from optimum versus maximum pore pressure ratio at the end of construction. From fig. 11 it can be seen that for dams with no internal drainage which might tend to influence pore pressures in the core, any water content dry of optimum by 0.5 percent or more seems to eliminate any significant development of pore pressures. For water contents greater than 0.5 percent dry of optimum, pore pressure ratios generally increase rapidly. Bishop 9 has noted that failure is likely to occur in a dam where the average pore pressure ratio throughout 

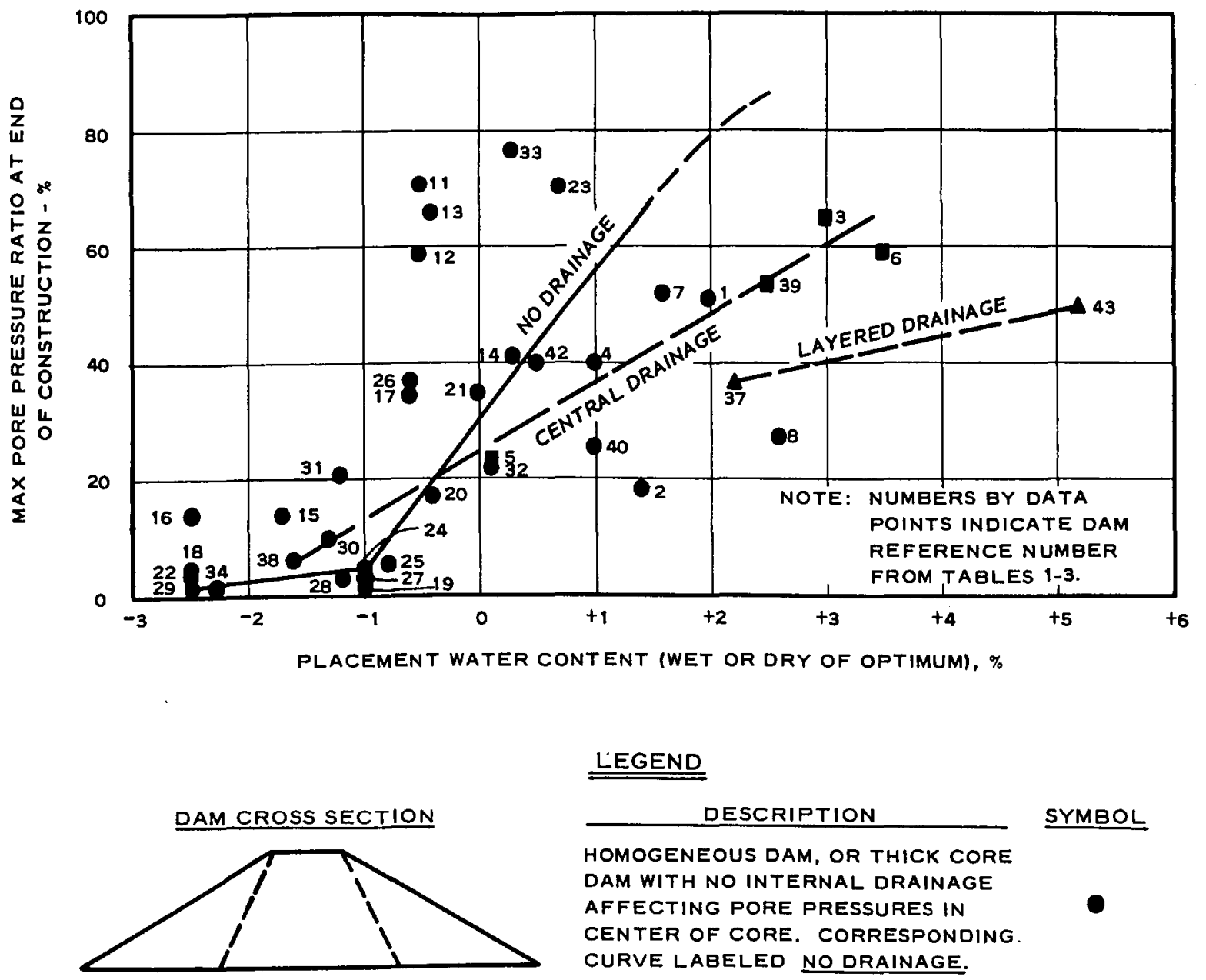

\section{LEEGEND}

DESCRIPTION
HOMOGENEOUS DAM, OR THICK CORE
DAM WITH NO INTERNAL DRAINAGE
AFFECTING PORE PRESSURES IN
CENTER OF CORE. CORRESPONDING
CURVE LABELED NO DRAINAGE.

SYMBOL

DAM WITH PERVIOUS DRAINAGE

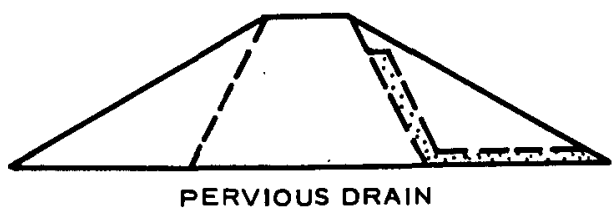
BLANKET EITHER WITHIN THE CORE OR IN SUCH A POSITION AS TO AFFECT DEVELOPMENT OF PORE PRESSURES. CORRESPONDING CURVE LABELED CENTRAL DRAINAGE.

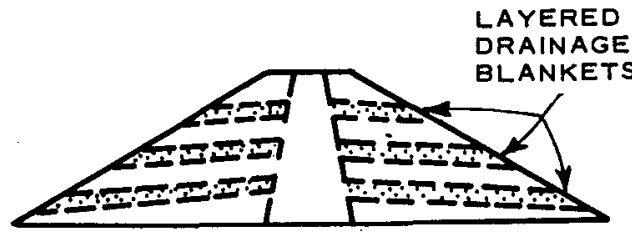

DAM WITH PERVIOUS DRAINAGE BLANKETS IN A LAYERED SYSTEM. CORRESPONDING CURVE LABELED LAYERED DRAINAGE.

Fig. 11. Maximum pore pressure ratio at end of construction versus water content 


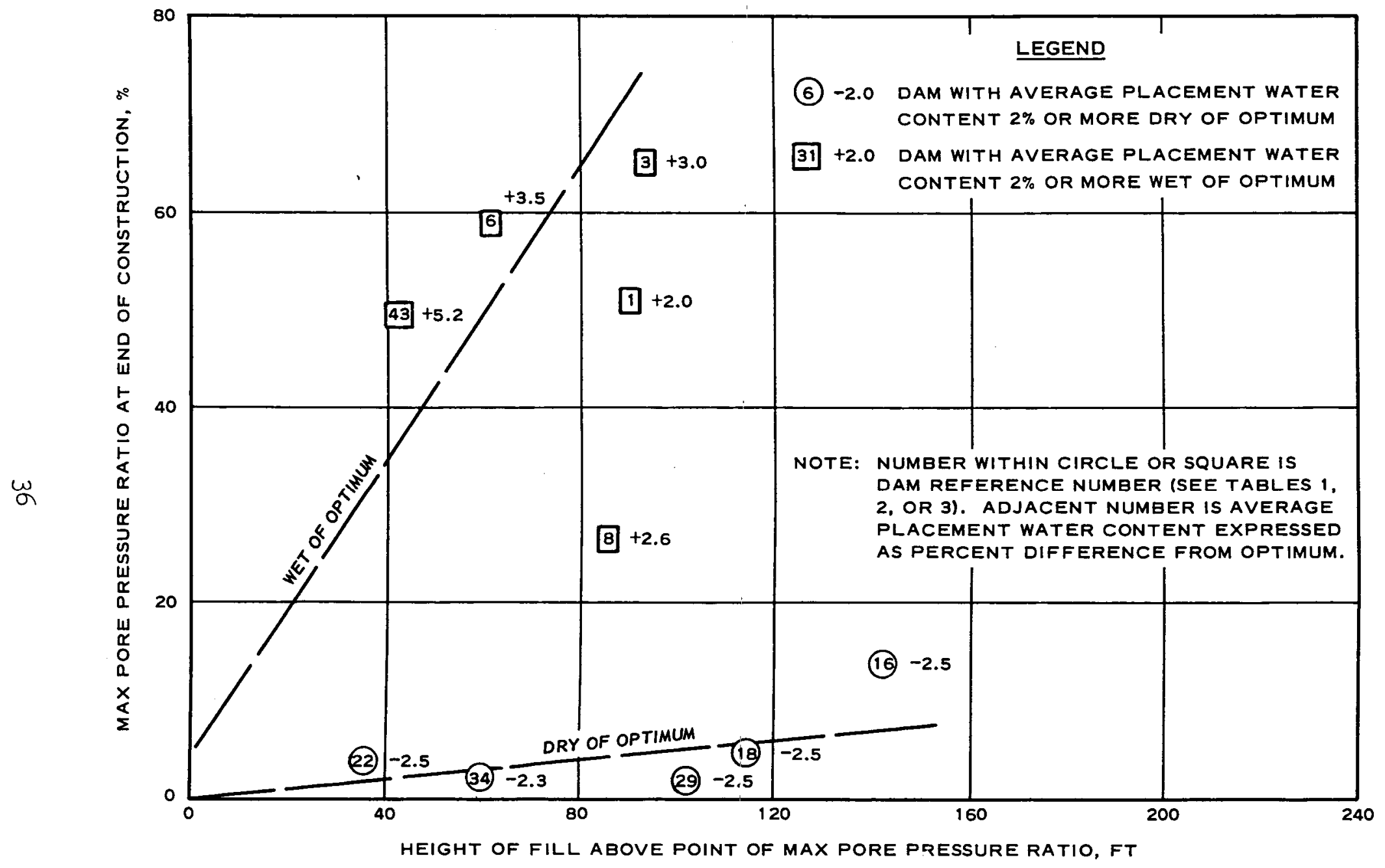

Fig. 12. Maximum pore pressure at end of construction versus fill height for dams compacted at over 2 percent wet or dry of optimum 
the entire cross section of the embankment exceeds 0.60 , except in the case of low dams.

64. Where internal drainage is provided adjacent to or within the core, dissipation of pore pressure occurs and subsequent increases in pore pressure with increasing fill height are at lesser ratios. The effect of drainage on the relation of pore pressure ratios and water content can be seen (fig. 11) in the two trend lines drawn for (a) dams with single drainage layers adjacent to or within the core and (b) dams with numerous drainage layers adjacent to or within the core. The slopes of the trend lines are progressively lessened as the drainage provisions become more extensive. But, significantly, an increase in pore pressure ratios with increasing water content is definitely indicated despite the drainage provisions.

65. Fig. 12 illustrates the effect of high and low water contents on the relation between fill height and pore pressure ratio. Pore pressure ratio increases with fill height, but the rate of this increase is controlled by the water content. In fact, the pore pressure ratio at any given fill height for dams compacted with an average placement water content more than 2 percent dry of optimum is only 5 percent of the value for dams with an average placement water content over 2 percent wet of optimum. Fill height

66. Fig. 12 demonstrates that for a limited water content variation the $u / \gamma \mathrm{h}$ ratio is influenced by fill height which in turn reflects such factors as the length of the drainage path and the degree of saturation. Fig. 13 shows fill height versus $u / \gamma \mathrm{h}$ ratio for all dams with an average placement water content between 0 to 2 percent dry of optimum. A general increase in $u / \gamma h$ ratio with fill height can be noted. A similar plot (fig. 14) for dams with average placement water content between 0 to 2 percent wet of optimum does not show as definite a relation. By examining the data in tables 1, 2, and 3 for all dams, two trends can be noted. For all dams studied regardless of soil type used for core material, if the core was constructed at about 1 percent or more on the dry side of the optimum water content, the pore pressure ratio is relatively low (less than 15 percent) regardless of dam height, fill height, or any other variable condition. However, as placement water content approaches or exceeds optimum 


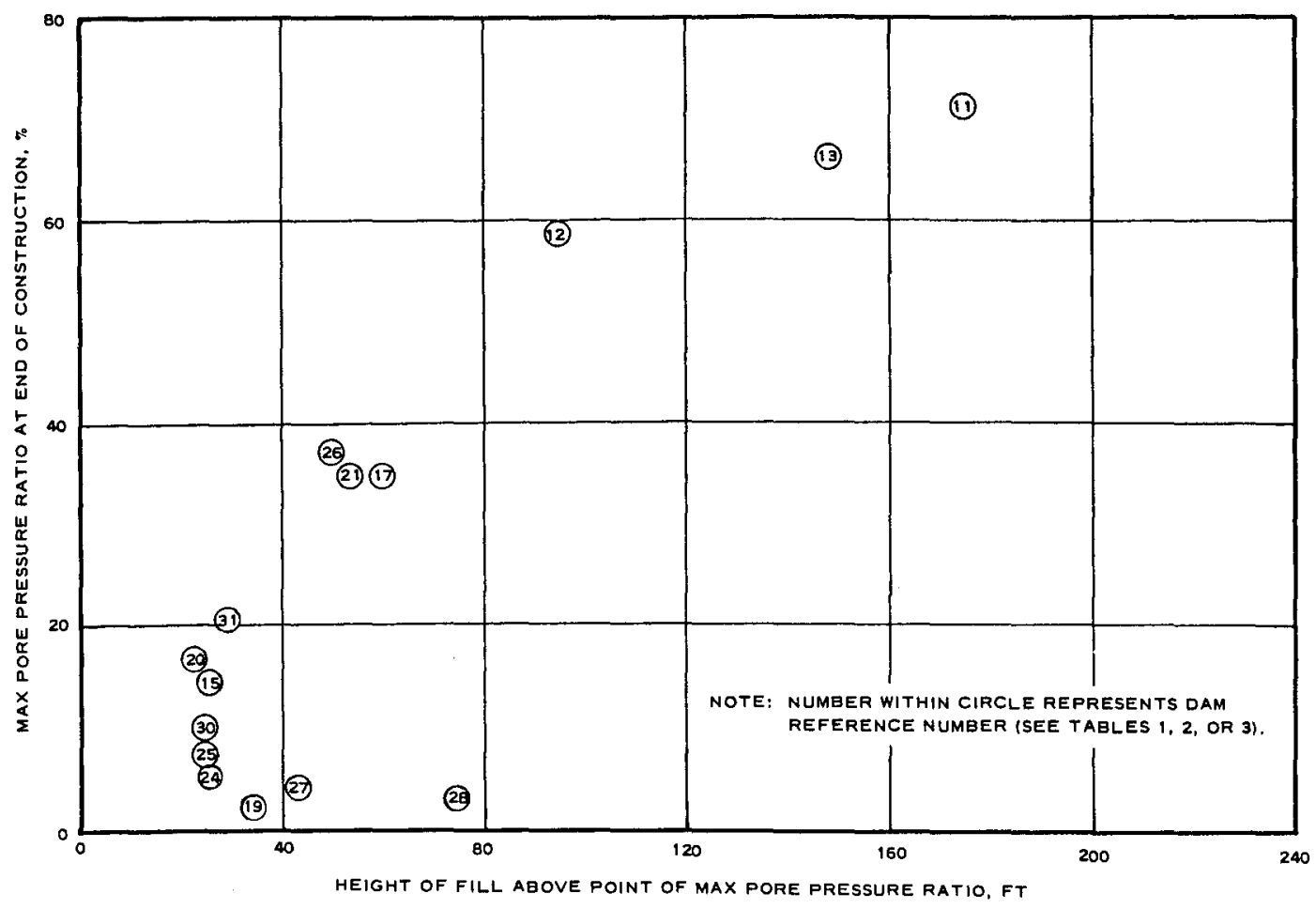

Fig. 13. Maximum pore pressure ratios at end of construction versus fill height for dams compacted 0 to 2 percent dry of optimum

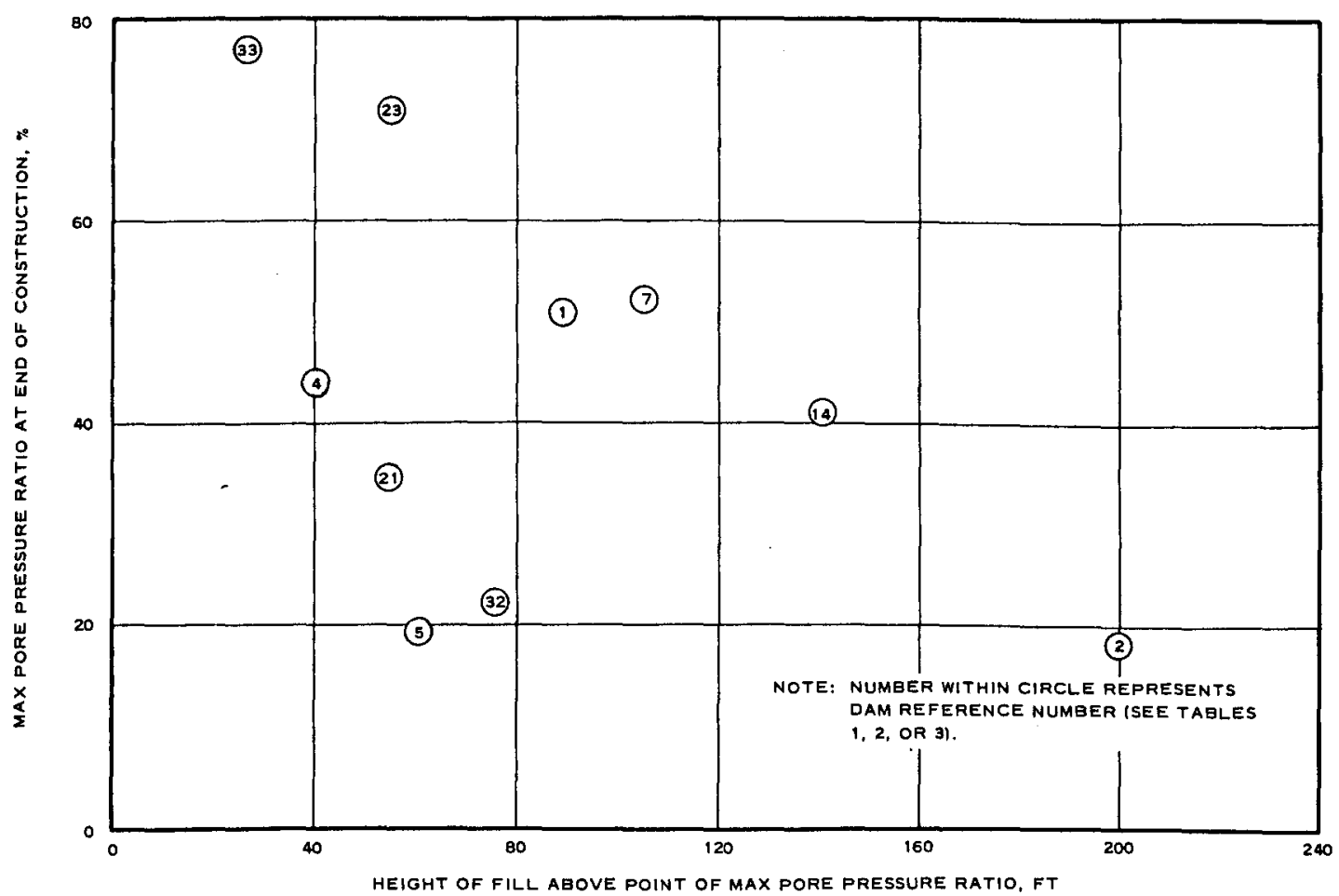

Fig. 14. Maximum pore pressure ratios at end of construction versus fill height for dams compacted 0 to 2 percent wet of optimum 
for the core material, the pore pressure ratio which may exist at end of construction is variable from low to high values and cannot be predicted from water content alone.

67. The conclusions readily drawn from figs. 12-14 are these:

a. From fig. 12 it is concluded that, on the average, embankment materials placed at 2 percent or more above optimum water content will develop significantly higher pore pressure ratios than those where the material is placed at 2 percent or more below optimum water content. Also, in general, an increase in fill height tends to increase the pore pressure ratio, all other variables being equal.

b. From fig. 13 it is concluded that when the embankment fill materials are placed on the dry side of optimum water content, an increase in fill height tends to result in an increase in pore pressure ratio, but at a slightly decreasing rate as the fill height approaches and exceeds $100 \mathrm{ft}$.

c. From fig. 14 showing points obtained from fills placed at water contents above optimum, it is concluded that as in fig. 13 (although with a much wider scattering of values) pore pressure ratios tend to increase in numerical value with increases in fill height, but at a slower rate of increase as fills extend toward 100 ft or more in height above the piezometer tip. This decreasing rate of pore pressure ratio increase is probably the result of consolidation of the soil around the piezometer tip as the fill pressures increase with fill height.

Compaction effort

68. The laboratory compaction tests used by the CE and the USBR differ in procedure, but the same amount of energy (equivalent to standard Proctor compaction effort) is applied to the soil sample in both cases. In actual dam construction, the USBR practice is to place the core material at a water content below optimum to avoid development of pore pressures, thereby requiring a greater compaction effort in the field to reach the maximum density. Note in table 2 that despite a variation of the placement water content down to 79 percent of optimum, the density in USBR dams never fell below 97 percent of the laboratory maximum density. Thus, it is important to note that for most USBR dams shown in fig. 11 as compacted on the dry side of optimum, pore pressures were very low. This indicates that water content has a greater effect on the development of pore pressures, even when compaction effort is relatively high. 
69. Fig. 15 is a plasticity chart showing the relative consistency of all impervious soils involved in this study. After a cursory examination of the soil type and corresponding $\mathrm{u} / \mathrm{\gamma h}$ ratios (see tables 1,2 , and 3 ), it is tempting to conclude that the $\mathrm{SC}$ soils tend to give high pore pressures and the ML soils low pore pressures. But in the case of the dams with SC soils and high pore pressures, the fill height is $100 \mathrm{ft}$ or more, and in the case of the dams with ML soils the associated placement water contents are always low, reflecting the previously discussed trends for water content and fill height; and the question remains unanswered as to how much these soil types affect the $u / \gamma \mathrm{h}$ ratios. SM, CL, CH, and SM-SC soil types all seem to give similar values of $u / \gamma \mathrm{h}$ ratios, varying with water content, dam height, etc.

Rate of construction

70. Rate of construction definitely influences the pore pressures established during construction, but not enough data were available in this study for a proper analysis. In the case of Hills Creek Dam, the effect of the rate of construction on the pore pressures developed could be observed, since the rate varied considerably during construction. Plate 18 , the plots of $u$ versus $\sigma_{1}$ for two selected piezometers, reflected the increases and decreases in rate of construction. This was discussed in paragraph 61 .

Drainage conditions

71. Drainage conditions and their influence on the $u / \gamma \mathrm{h}$ ratio have been extensively discussed in several of the preceding sections, but the importance of their influence impels their recognition as a separate entity that affects the magnitude of the $u / \gamma \mathrm{h}$ ratio. As has been shown by Bishop 9 and $\mathrm{Li}^{2}{ }^{29}$ any method of predicting construction pore pressure which ignores the effects of dissipation when such occurs will be conservative. Certainly, the results from CE dams have substantiated such an observation. It should be noted that even if internal core drains are not provided in a dam, boundary drainage will occur wherever more pervious material is adjacent to the core (i.e. granular shells, pervious foundations, etc.). According to Hilf, ${ }^{25}$ however, this type of drainage, particularly when the 


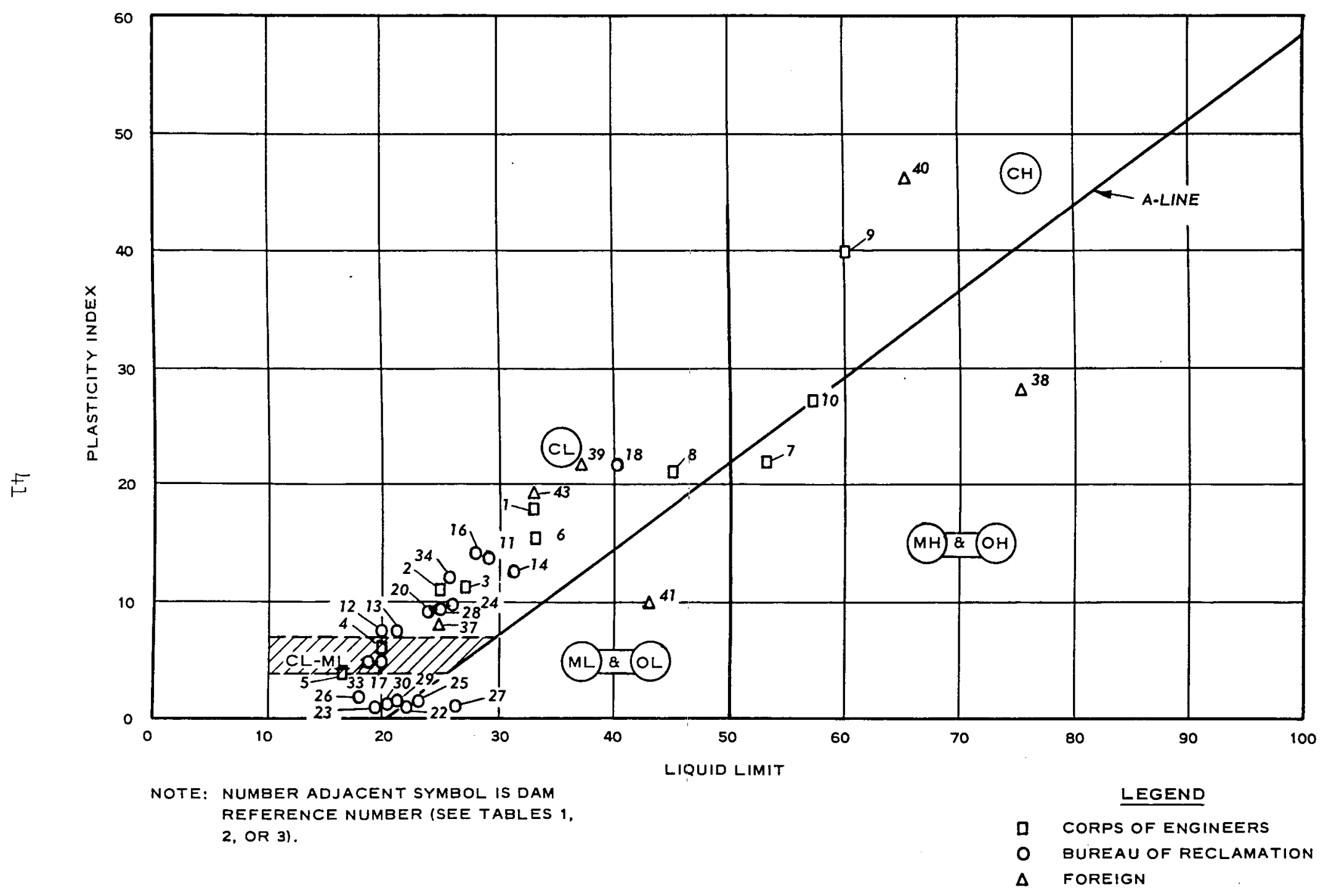

Fig. 15. Plasticity chart showing relative consistency of impervious soils of dams used in this study 
core is relatively thick, is usually not effective as it does not affect the central portion of the core.

Other factors

72. Piezometer system. A thorough discussion of the technical differences between the various piezometer systems used in the dams examined in this study lies outside the scope of this report. Piezometer designs have been changed and made more efficient since their first use, and this fact in itself implies that the differences in design would have some effects on the readings which were used in the analyses. A tabulation of the dams showing the various types of piezometer systems used is given in Appendix B. Common sources of error associated with various piezometer types are discussed in reference 57.

73. Deviation of conditions from the mean. All of the values of water content, density, etc., reported are the weighted mean values found by various sampling techniques. Although it is recognized that some random variation of these quantities is to be expected, in several cases because of the erratic nature of the borrow materials, heavy rainfall during fill placement, etc., significant amounts of material were placed which deviated from the average conditions. These materials yielded pore pressures which appeared contradictory to the average conditions. Such a case was reported by Gould ${ }^{23}$ as the cause of the exceptionally high pore pressure at Fresno Dam. Unfortunately, these conditions, if they occurred, were not always reported, thus adding to the scatter of results.

\section{$\underline{\text { Summary }}$}

74. The observations made from the data presented in Part III were not intended to represent a new approach to the problem of predicting construction pore'pressures, but rather were to inform and aid in anticipating problems which might arise under given conditions. In summary, the following statements can be made for conditions within the limits of the data examined.

a. Factors which affect the buildup of construction pore pressures are numerous. Placement water content, overburden weight, length of drainage path, rate of construction including construction stoppages, nature of the core material, and presence of drainage features all exert some effect. 
Because of the interdependence of these factors, it is difficult to isolate the relative influence of any one factor on the development of construction pore pressures.

b. Provision for internal drainage or the use of relatively thin impervious core zones will significantly retard development of construction pore pressures.

c. During construction, pore pressures at a given point within an embankment will increase as the overlying weight of fill increases. However, as pore pressures dissipate with time, the rate of pore pressure increase with increasing overburden pressure is lessened.

d. Increasing the rate of construction results in an increasing rate of increase of pore pressures with overburden pressure.

e. For placement water contents on the wet side of optimum water content, pore pressure ratios rapidly increase with increasing water content, but the increase is somewhat moderated by internal drainage.

f. Pore pressure ratios generally increase with increasing dam height; the degree of increase depends on variables stated in paragraph 74 a above.

g. Low dams (less than $100 \mathrm{ft}$ in height) as well as high dams are subject to development of significant pore pressures when the placement water content is above optimum.

h. From the limited data available for various compacted soil types, it appears that fine-grained SM, CL, CH, and SM-SC soil types are all likely to produce comparable pore pressures under similar conditions.

i. As can be seen from the scatter of data in figs. 11-14, each dam should be handled as an individual case and analyzed from an overall standpoint for possible influencing factors. 


\section{Conclusions}

75. Of all the methods of estimating embankment pore pressures discussed in Part II, only the Hilf-Brahtz method as described by Gould ${ }^{23}$ and Bishop's method ${ }^{7,9}$ have been substantially documented by field results. For the no-drainage conditions encountered in the case of a dam with a relatively thick impervious core and no internal drains, the Hilf-Brahtz theory has been shown by Gould to serve as a good estimation of embankment pore pressures. Data necessary for use in the method are easily found, and the method is convenient to apply. But in the case of a dam with a core likely to allow dissipation of pore pressures during construction, i.e. a core with a permeability greater than $10^{-6} \mathrm{~cm}$ per sec, 39 or in the case of a dam in which an internal drainage system is provided sufficiently close to the core to cause relief of pore pressures, the Bishop method or a reasonable method accounting for the "twofold" effect of dissipation of pore pressures (see paragraphs 16 and 21) should be applied. Bishop 9 and $\mathrm{Li}^{29}$ have shown the necessity of considering pore pressure dissipation, and this has been thoroughly supported by results from CE dams.

76. Placement water content is the most significant factor in the initial buildup of pore pressures during construction of earth embankments. Above approximately optimum water content, substantial pore pressures can be anticipated unless drainage provisions are supplied.

77. Low dams (less than $100 \mathrm{ft}$ in height) can develop significant pore pressures when compacted at placement water contents on the wet side of optimum, contrary to some published opinions.

78. The downstream chimney drain provides effective relief of construction pore pressures. As employed by the $\mathrm{CE}$, the chimney drain serves to dissipate pore pressures in areas adjacent to the drains during construction and thereby reduces the rate of their increase upon additional fill placement. 
79. For a more complete understanding of the mechanics of pore pressure development during constmuction, it is reconmended that:

a. Piezometers be installed in earth dams where significant pore pressures are anticipated, and observed during and after construction.

b. Piezometric measuring devices for $\mathrm{CE}$ dams be standardized.

c. More extensive research be made into the relation of soil type, placement conditions, and compaction effort in development of pore pressures.

d. Forms to be used by the $\mathrm{CE}$ in collecting field data be standardized.

e. Basic research be conducted concerning the relation of pore pressure magnitude during construction and consolidation of partially saturated, compacted soils. This would include attempts at correlation of predicted pore pressures and actual values obtained in the prototype structure. 
1. Alpan, I., "The dissipation function for unsaturated soils." Proceedings, Fifth International Conference on Soil Mechanics and Foundation Engineering, Paris, vol 1 (1961), p 3 .

2. Banks, J. A., "Problems in the design and construction of Knockendon Dam." Proceedings, Institution of Civil Engineers, vol 1 (July 1952), pp 423-443.

3. Bernell, L., "The properties of moraines." Proceedings, Fourth International Conference on Soil Mechanics and Foundation Engineering, London, vol 2 (1957), pp 286-290.

4. Bernell, L, and Nilsson, R., "Electrical analogy equipment for solving non-stationary two-dimensional flow problems." Proceedings, Fourth International Conference on Soil Mechanics and Foundation Engineering, London, vol 2 (1957), pp 291-293.

5. Bernell, L., "Determination of pore pressures in earth dams during construction." Transactions, Sixth International Congress on Large Dams, New York, vol 2, Q 21, R 116 (1958).

6. Bishop, A. W., The Stability of Earth Dams. Ph. D. Thesis, University of London, 1952.

7. Geotechnique, vol 4, No. 4 (1954), pp 148-152.

8. , discussion of paper, "The Usk scheme for the water supply of Swansea," by G. A. R. Sheppard and L. B. Aylen. Proceedings, Institution of Civil Engineers, vol 7 (1957), p 271.

9. "Some factors controlling the pore pressure set up during the construction of earth dams." Proceedings, Fourth International Conference on Soil Mechanics and Foundation Engineering, London, vol 2 (1957), pp 294-300.

10. Bishop, A. W., Kennard, M. F., and Penman, A. D. M., "Pore pressure observations at Selset Dam." Pore Pressure and Suction in Soil Conference, London (1960), pp 36-47.

11. Bishop, A. W., and Bjerrum, L., "The relevance of the triaxial test to the solution of stability problems." Proceedings, ASCE Research Conference on Shear Strength of Cohesive Soils, Denver (1960), p 437.

12. Bjerrum, I., Theoretical and Experimental Investigations on the Shear Strength of Soils. Publication No. 5, Norwegian Geotechnical Institute, Oslo, Norway, 1954.

13. Bruggeman, J. R., Zanger, C. N., and Brahtz, J. H. A., Notes on Analytical Soil Mechanics. Technical Memorandum No. 592, U. S. Bureau of Reclamation, Denver, Colo., June 1939.

14. Burt, E. J., "Installation and operation of piezometer system in Cobb earth dam." New Zealand Engineering, vol 10, No. 11 (November 1955), pp 361-367. 
15. Collins, N. W., "Construction pore pressures in the Cobb earth dam." New Zealand Engineering, vol 10, No. 11 (November 1955), pp 368-376.

16. Daehn, W. W., and Hilf, J. W., "Implications of pore pressure in design and construction of rolled earth dams." Transactions, Fourth International Congress on Large Dams, New Delhi, vol 1, R 39 (1951), p 259.

17. Dixon, H. H., Edington, G. A., and FitzGerald, E. P., "The ChaniaSasumua water supply for Nairobi." Proceedings, Institution of Civil Engineers, vol 9 (1958), pp 345-368.

18. Dixon, H. H., "Moisture control and compaction methods used during the construction of the Sasumua Dam, Kenya." Transactions, Sixth International Congress on Large Dams, New York, vol 3, Q 22, R. 10 (1958).

19. Esmiol, E. E., "The diversity of impervious soils used in Bureau of Reclamation earth dams." Proceedings, Third International Conference on Soil Mechanics and Foundation Engineering, Zurich, vol 2 (1953), pp 224-229.

20 . - Impervious Soils Used in Rolled Earth Dams. Technical Memorandum No. 649, U. S. Bureau of Reclamation, Denver, Calo., 1954.

21. Gibson, R. E., and Henkel, D. M., "Influence of duration of tests at constant rate of strain on measured 'drained' strength." Geotechnique, vol 4, No. 1 (March 1954), pp 6-15.

22. Gould, J. P., Compression Characteristics of Rolled Fill Materials in Earth Dams. Technical Memorandum No. 648, U. S. Bureau of Reclamation, Denver, Colo., March 1954.

23. , Construction Pore Pressures Observed in Rolled Earth Dams. Technical Memorandum No. 650, U. S. Bureau of Reclamation, Denver, Colo., 1959.

24. Henkel, D. J., and Skempton, A. W., "A landslide at Jackfield." Proceedings, European Conference on Stability of Earth Slopes, Stockholm, Vol I (1955), p 90 .

25. Hilf, J.W., "Estimating construction pore pressures in rolled earth dams." Proceedings, Second International Conference on Soil Mechanics and Foundation Engineering, Rotterdam, vol 3 (1948), p 234.

26. An Investigation of Pore-Water Pressure in Compacted Cohesive Soils.' Technical Memorandum No. 654, U. S. Bureau of Reclamation, Denver, Colo., October 1956.

27. Jones, O. T., "Construction of the Cobb earth dam." New Zealand Engineering, vol 10, No. 11 (1955), p 373.

28. LeMoigne, G., The Determination of Pore Pressures in Earth Dams. M. S. Thesis, Cornell University, 1957.

29. Li, C. Y., "Construction pore pressures in an earth dam." Proceedings, ASCE, Soil Mechanics and Foundations Division Journal, vol 85 , No. SM 5, Paper No. 2213 (October 1959), pp 43-59. 
30. Linell, K. A., and Shea, H. F., "Strength and deformation characteristics of various glacial tills in New England." Proceedings, ASCE Conference on Shear Strength of Cohesive Soils, Denver (1960), p 275.

31. Iittle, A. L., "Compaction and pore water pressure measurements on some recent earth dams." Transactions, Sixth International Congress on Large Dams, vol 3, Q 22, $\mathrm{R} 42$ (1958).

32. Nilsson, T., and Löfquist, B., "An earth and rockfill dam on stratified soil; the wet-fill method." Transactions, Fifth International Congress on Large Dams, Paris, vol 1, Q 16, R 32 (1955).

33. Nonveiller, E., "Pore pressure in the Lokvarka Dam." Proceedings, Fourth International Conference on Soil Mechanics and Foundation Engineering, London, vol 2 (1957), p 341-347.

34. Nonveiller, E. E., "Compaction methods and moisture content for materials used in the construction of earth core and supporting fill for earth and rockfill dams." Transactions, Sixth Congress on Large Dams, New York, vol 3, Q 22, GR-G, General Report (1958).

35. Rufenacht, A., "Pore pressure assumptions for stability studies of earth dams." Proceedings, Second International Conference on Soil Mechanics and Foundation Engineering, Rotterdam, vol 3 (1948), pp 230-240.

36. Schiltknecht, R., and Bickel, H., "Control measurements at the Castiletto earth dam." Proceedings, Fourth International Conference on Soil Mechanics and Foundation Engineering, London, vol 2 (1957), pp 373-377.

37. Scott, P. A., "Observations on an experimental clay embankment to assist the design of the impermeable layer of a large rockfill dam." Transactions, Sixth International Congress on Large Dams, New York, vol 3, Q 22, R 57 (1958).

38. Sheppard, G. A. R., and Aylen, L. B., "The Usk scheme for the water supply of Swansea." Proceedings, Institution of Civil Engineers, vol 7 (June 1957), pp 246-265.

39. Sherard, J. I., and others, Earth and Earth-Rock Dams; Engineering Problems of Design and Construction. John Wiley and Sons, Inc., New York, N. Y., 1963.

40. Skempton, A. W., "The effective stresses in saturated clays strained at constant volume." Proceedings, Seventh International Congress of Applied Mećhanics, vol I (1948), pp 378-392. 41. vol 4, No.'4 "(1954), p 143 .

42. Skempton, A. W., and Bishop, A. W., "The gain in stability due to pore pressure dissipation in a soft clay foundation." Transactions, Fifth International Congress on Large Dams, Paris, vol 1, Q 16, R 57 (1955).

43. Skempton, A. W., Bishop, A. W., and Cooling, I. F., discussion of paper, "Design and performance of the Sasumua Dam," by Karl Terzaghi. 
Proceedings, Institution of Civil Engineers, vol 11 (November 1958), pp 344-346 and 348-352.

44. Tcherepennikoff, I., "Determination des conditions optima de mise en place des remblais (Determination of optimum conditions for placing earth embankments)." Annales des Ponts et Chaussées, (Janvier 1955).

45. Terzaghi, Karl, and Fröhlich, O. K., Theorie der Setzung von

Tonschichten; Eine Einfïhrung in die analytische Tonmechanik. Franz Deuticke, Leipzig und Wien (1936).

46. Terzaghi, Karl, "Design and performance of the Sasumua Dam." Proceedings, Institution of Civil Engineers, vol 9 (April 1958), pp 369-394.

47. Treiber, Friedrich, "Measurements and observations on Rosshaupton Dam." Transactions, Sixth International Congress on Large Dams, New York, vol 2, Q 21, R 5 (1958).

48. , "Compaction methods adopted for the construction of Rosshaupton Dam, their effectiveness, and the behavior of the impervious loam core." Transactions, Sixth International Congress on Large Dams, New York, vol 3, Q 22, R 8 (1958).

49. Turnbull, W. J., and Shockley, W. G., "Compaction of earth dams in the Corps of Engineers, U. S. Army." Transactions, Sixth International Congress on Large Dams, New York, vol 3, Q 22, R 96 (1958).

50. U. S. Army Engineer District, Huntington, Report on the Installation of Vertical Sand Drains, Dewey Reservoir Project, John's Creek,

Kentucky. Huntington, W. Va., June 1950.

51. U. S. Army Engineer District, Kansas City, Pomme de Terre Dam and Reservoir, Design Memorandum No. 11, Soil Data and Embankment Design. Kansas City, Mo., February 1957.

52. U. S. Army Engineer Division, New England, Otter Brook Dam and Reservoir, Design Memorandum No. 7, Embankment Design. Boston, Mass., June 1955 .

53. North Hartland Dam and Reservoir, Design Memorandum No. 6, Part B, Materials. Boston, Mass., May 1957.

54.

55. , North Hartland Dam and Reservoir, Design Memorandum No. 7, Embankment Design. Boston, Mass., June 1957.

5. Mad River Dam and Reservoir, Design Memorandum No. 5, Embankments and Foundations. Boston, Mass., January 1961.

56. U. S. Army Engineer District, Portland, Hills Creek Reservoir, Middle Fork Willamette River, Oregon, Design Memorandum No. 13, Foundation Grouting and Drainage. Portland, Oreg., October 1956.

57. U. S. Army Engineer Waterways Experiment Station, CE, Time Iag and Soil Permeability in Ground-Water Observations. Bulletin No. 36, Vicksburg, Miss., April 1951.

58. Review of Soils Design, Construction, and Prototype Analysis, Blakely Mountain Dam, Arkansas. Technical Report No. 3-439, Vicksburg, Miss., October 1956. 
59. U. S. Army Engineer Waterways Experiment Station, CE, Review of Soils Design, Construction and Prototype Observations, Texarkana Dam, Texas. Technical Report No. 3-484, Vicksburg, Miss., September 1958.

60. , Review of Soils Design, Construction, and Prototype Observations, Ferrells Bridge Dam, Texas. Technical Report No. 3-538, Vicksburg, Miss., March 1960.

61. , Review of Stability Analysis, Table Rock Dam. MiscelIaneous Paper No. 3-544, Vicksburg, Miss., November 1962. 
Table 1

Placement and Pore Pressure Data for Impervious Core Zones, CE Dams

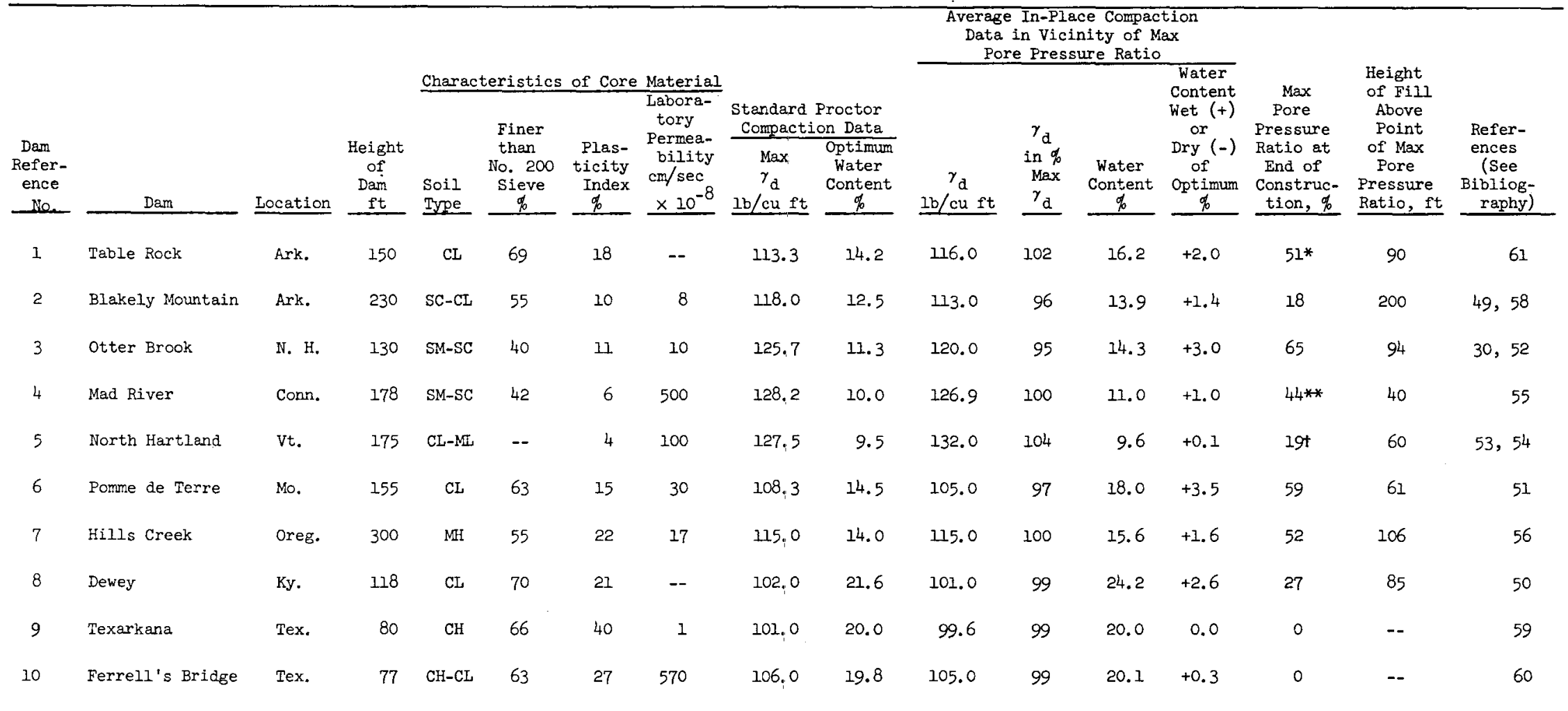

Note: In addition to references shown and given in Bibliography, data were obtained through correspondence with CE Division Offices.

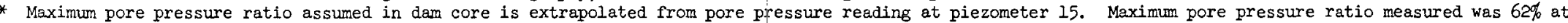
piezometer 12, which is not located in the core.

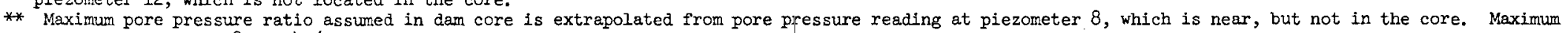
ratio at piezometer 8 was $40 \%$.

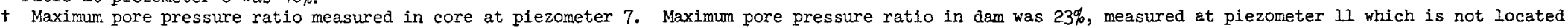
in the center of the dam. 
Table 2

Placement and Pore Pressure Data for Impervious Core Zones, USBR Dams

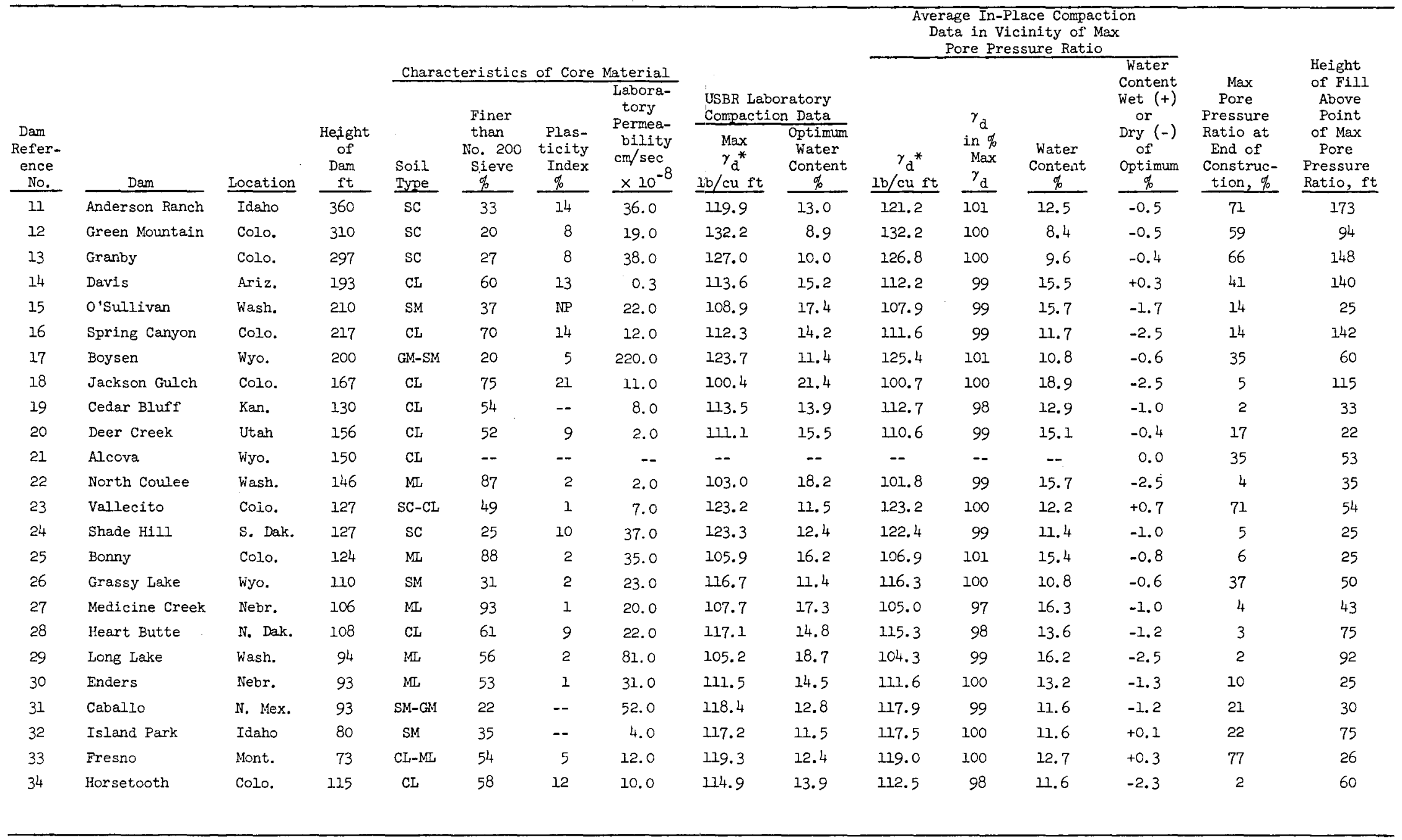

Note: Information based on items 20 and 23 in Bibliography.

* Material passing No. 4 sieve only. 
Table 3

\section{Placement and Pore Pressure Data for, Impervious Core Zones, Foreign Dams}

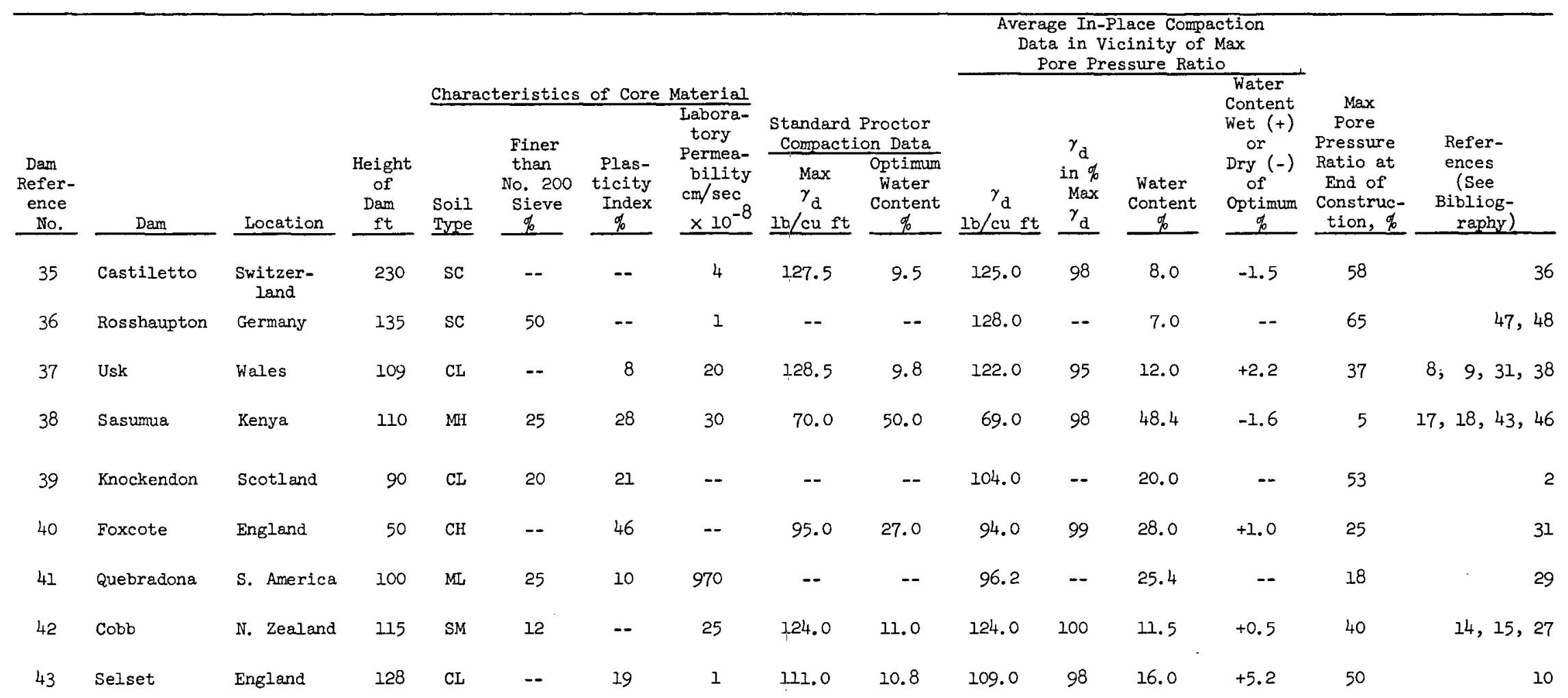


Table 4

Selected Piezometer Data for Selected Dams

\begin{tabular}{|c|c|c|c|c|c|c|c|c|c|c|c|c|c|c|c|c|c|c|c|c|}
\hline \multirow{2}{*}{$\begin{array}{l}\text { Dem } \\
\text { Refer- } \\
\text { ence } \\
\text { No. } \\
\end{array}$} & \multirow[b]{2}{*}{ Dam } & \multirow[b]{2}{*}{ Agency } & \multirow{2}{*}{$\begin{array}{l}\text { Piezom- } \\
\text { eter } \\
\text { No. } \\
\end{array}$} & \multirow{2}{*}{ 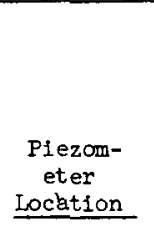 } & \multirow[t]{2}{*}{$\begin{array}{l}\text { Eleva- } \\
\text { tion } \\
\text { Piezom- } \\
\text { eter } \\
\text { Tip, ft } \\
\text { MSL } \\
\end{array}$} & \multirow[t]{2}{*}{$\begin{array}{l}\text { Final } \\
\text { Fill } \\
\text { Eleva- } \\
\text { tion } \\
\text { above } \\
\text { Plezom- } \\
\text { eter } \\
\text { ft, MSL }\end{array}$} & \multirow[t]{2}{*}{$\begin{array}{l}\text { Horizontal } \\
\text { Distance to } \\
\text { Nearest } \\
\text { Drainage } \\
\text { Surface } \\
\text { ft } \\
\end{array}$} & \multirow{2}{*}{$\begin{array}{c}\begin{array}{c}\text { Nature } \\
\text { of }\end{array} \\
\text { Drainage } \\
\text { Surface } \\
\end{array}$} & \multicolumn{3}{|c|}{$\begin{array}{c}\text { Feet of Fill } \\
\text { Placed above } \\
\text { Piezometer } \\
\text { During } \\
\text { Construction } \\
\text { Season } \\
\end{array}$} & \multicolumn{3}{|c|}{$\begin{array}{l}\text { Time of Fill above } \\
\text { Piezometer, Months }\end{array}$} & \multicolumn{3}{|c|}{$\begin{array}{r}\overline{\mathrm{B}} \text { Values Durin } \\
\text { Season abov } \\
\end{array}$} & \multicolumn{2}{|c|}{$\begin{array}{l}18 \text { Construction } \\
\text { e Plezometer }\end{array}$} & \multirow{2}{*}{$3 \mathrm{~d}$} \\
\hline & & & & & & & & & 1st & $2 \mathrm{~d}$ & $\underline{3 d}$ & Ist & $2 \mathrm{~d}$ & $3 d$ & & Ist & & 2 & & \\
\hline \multirow[t]{2}{*}{11} & $\begin{array}{l}\text { Anderson } \\
\text { Ranch }\end{array}$ & USBR & 9 & $\begin{array}{l}180 \mathrm{ft} \text { US } \\
\text { of axis }\end{array}$ & 3855 & 4148 & 200 & $\begin{array}{l}\text { Granular } \\
\text { shell }\end{array}$ & 40 & 95 & 113 & 6 & 5 & $6-1 / 2$ & $0.7^{4}$ & -- & -- & 0.60 & -- & 0.73 \\
\hline & & & 16 & $\begin{array}{l}30 \text { ft US } \\
\text { of axis }\end{array}$ & 3941 & 4198 & 130 & $\begin{array}{l}\text { Granular } \\
\text { she'11 }\end{array}$ & 95 & 113 & 28 & 5 & $6-1 / 2$ & $2-3 / 4$ & 0.38 & -- & -- & 0.76 & -- & 0.22 \\
\hline 12 & $\begin{array}{l}\text { Green } \\
\text { Mountain }\end{array}$ & USRR & 13 & $\begin{array}{l}150 \mathrm{ft} \text { US } \\
\text { of axis }\end{array}$ & 7760 & 7912 & 230 & $\begin{array}{l}\text { Grandilar } \\
\text { shell }\end{array}$ & 68 & 84 & -- & $3-3 / 4$ & $4-1 / 4$ & $=$ & 0.48 & -- & -- & 0.45 & -- & -- \\
\hline \multirow[t]{2}{*}{13} & Granby & USBR & 57 & $\begin{array}{l}240 \mathrm{ft} \text { US } \\
\text { of axis }\end{array}$ & 8060 & 8208 & 100 & $\begin{array}{l}\text { Granular } \\
\text { shell }\end{array}$ & 148 & -- & -- & 5 & -- & - & 0.68 & -- & $\cdots$ & -- & -- & -- \\
\hline & & & 60 & $\begin{array}{l}30 \mathrm{ft} \text { US } \\
\text { of } \mathrm{axis}\end{array}$ & 8060 & 8250 & 200 & $\begin{array}{l}\text { Granular } \\
\text { shell }\end{array}$ & 190 & -- & -- & 6 & -- & -- & 0.40 & -- & -- & -- & -- & -- \\
\hline 23 & Vallecito & USBR & 23 & Axis & 7610 & 7673 & 95 & $\begin{array}{l}\text { Granilar } \\
\text { shell }\end{array}$ & & 46 & -- & & $6-1 / 2$ & -- & -- & -- & -- & 0.67 & -- & - \\
\hline \multirow[t]{2}{*}{3} & $\begin{array}{l}\text { Otter } \\
\text { Brook }\end{array}$ & $\mathrm{CE}$ & $1-A$ & $\underline{E}$ & 704 & 801 & 70 & $\begin{array}{l}\text { Pervious } \\
\text { drain }\end{array}$ & 97 & -- & -- & 3 & -- & - & 0.35 & 0.12 & -- & - & -- & -- \\
\hline & & & $3-A$ & $\underline{L}$ & 708 & 801 & 70 & $\begin{array}{l}\text { Pervious } \\
\text { artin }\end{array}$ & 93 & -- & -- & 3 & -- & - & 0.66 & 0.10 & -- & - & -- & -- \\
\hline 4 & Mad River & $\mathrm{CE}$ & 2 & $\notin$ & 880 & 996 & 70 & $\begin{array}{l}\text { Pervious } \\
\text { drain }\end{array}$ & 116 & - & - & $3-3 / 4$ & -- & -- & 0.81 & 0.24 & 0.08 & -- & -- & -- \\
\hline 5 & $\begin{array}{l}\text { North } \\
\text { Hartiand }\end{array}$ & $\mathrm{CE}$ & 9 & $\notin$ & 475 & 572 & 30 & $\begin{array}{l}\text { Pervious } \\
\text { drain }\end{array}$ & 62 & 35 & -- & $3-1 / 2$ & 5 & -- & 0.58 & -- & -- & 0.12 & 0.02 & -- \\
\hline \multirow[t]{2}{*}{7} & $\begin{array}{l}\text { Hills } \\
\text { Creek }\end{array}$ & $\mathrm{CE}$ & 1 & $\begin{array}{l}10 \text { ft US } \\
\text { of } \mathbb{Z}\end{array}$ & 1250 & 1522 & 35 & $\begin{array}{l}\text { Gravel } \\
\text { shel1 }\end{array}$ & 172 & 100 & -- & $6-1 / 2$ & $5-1 / 2$ & -- & 0.72 & 0.12 & -- & 0.02 & 0.84 & -- \\
\hline & & & 13 & $\begin{array}{l}10 \mathrm{ft} D S \\
\text { of } \mathrm{E}^{\mathrm{D}}\end{array}$ & 1370 & 1522 & 15 & $\begin{array}{l}\text { Gravel } \\
\text { shell }\end{array}$ & 52 & 100 & -- & $1-1 / 4$ & $5-1 / 2$ & -- & 0.50 & -- & -- & 0.19 & 0.85 & -- \\
\hline
\end{tabular}

Note: US and DS denote upstream and downstream, respectively. 
DISTANCE FROM CENTER LINE OF DAM, FT

\begin{tabular}{lllllll}
500 & 400 & 300 & 200 & 100 & 0 & 100 \\
\hline
\end{tabular}

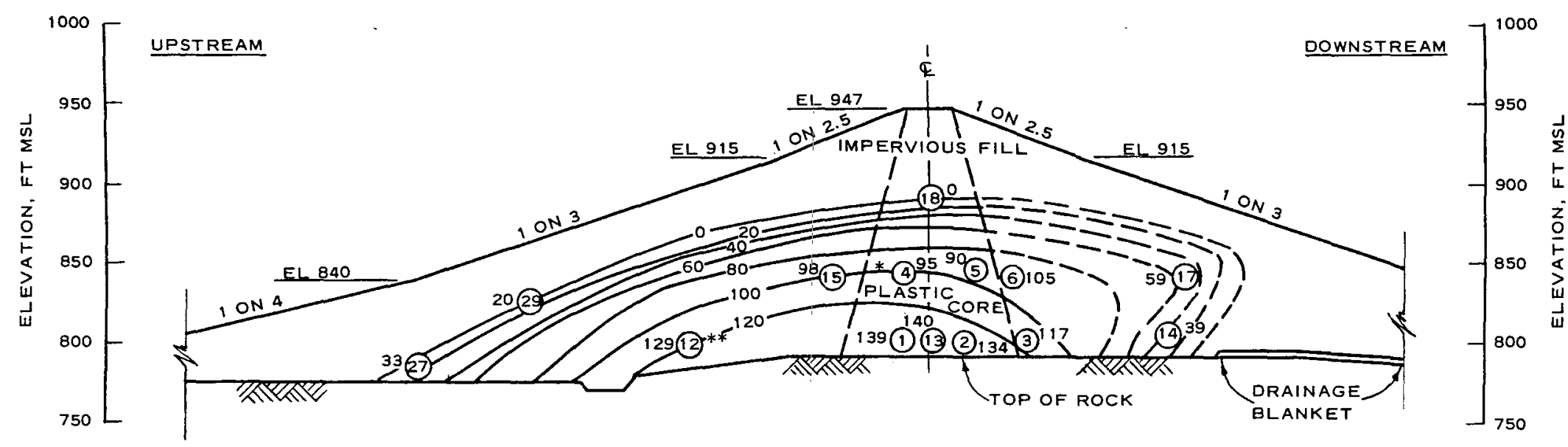

NOTE: CORE MATERIAL = SANDY CLAY (CL), CLAY $(C L), C L A Y(C H)$ IMPERVIOUS FILL = SANDY CLAY (CL), CLAY (CL) DASHED CONTOUR LINES ARE INFERRED ONLY

* maximum pore pressure ratio in dam core (assumed from contours)

$\mu=(100 \times 62.4) \mathrm{PSF}$

$\gamma=136 \mathrm{PCF}, h=90 \mathrm{FT}$

$\frac{\mu}{y h}=51 \%$

** MAXIMUM PORE PRESSURE RATIO (AT PIEZOMETER NO. 12)
$\mu=(129 \times 62.4) \mathrm{PSF}$
$\gamma=136 \mathrm{PCF}, h=96 \mathrm{FT}$
$\frac{\mu}{\gamma h}=62 \%$

\section{LEGEND}

(13) 140 PIEZOMETER LOCATION; CIRCLED NUMBER IS PIEZOMETER NUMBER, ADJACENT NUMBER IS PIEZOMETER READING IN FEET OF WATER.

PIEZOMETRIC CONTOURS AT END OF CONSTRUCTION TABLE ROCK DAM 
DISTANCE FROM CENTER LINE OF DAM, FT

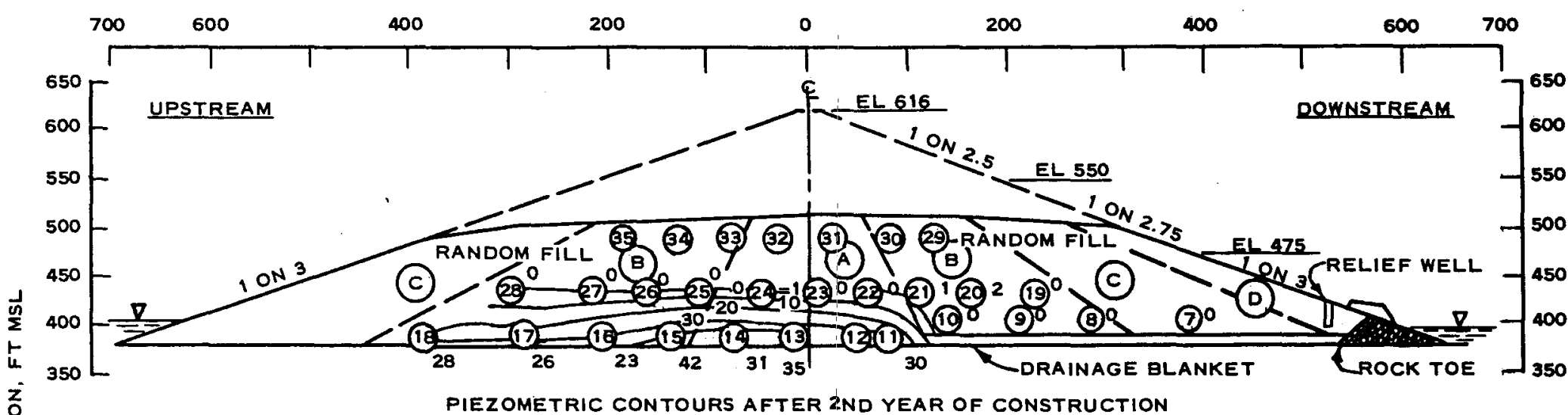

PIEZOMETRIC CONTOURS AFTER 2ND YEAR OF CONSTRUCTION

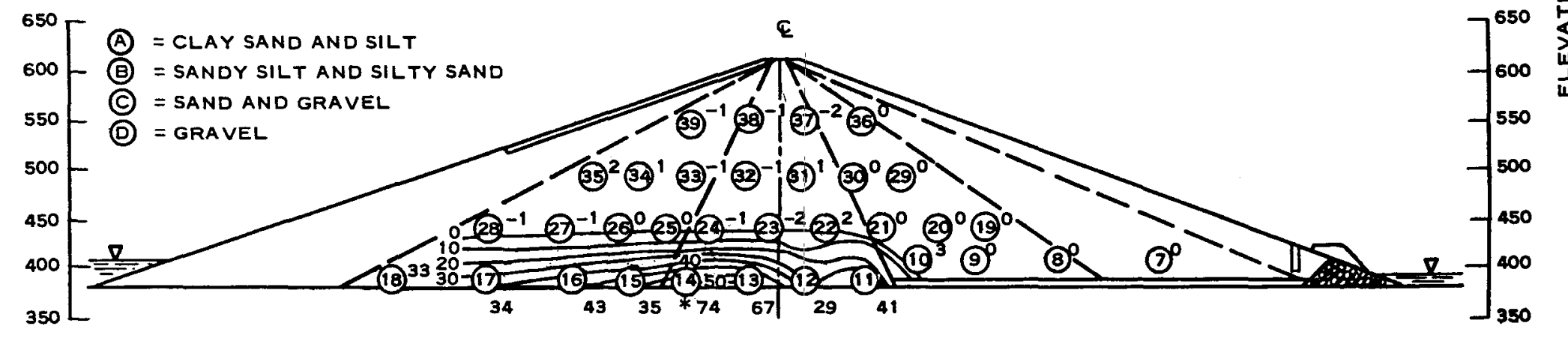

PIEZOMETRIC CONTOURS AT END OF CONSTRUCTION

* maximum pore pressure ratio AT PIEZOMETER 14.

$$
\begin{aligned}
\mu & =(74 \times 62.4) \mathrm{PSF} \\
\gamma & =129 \mathrm{PCF} \\
h & =200 \mathrm{FT} \\
\frac{\mu}{\gamma h} & =18 \%
\end{aligned}
$$

LEGEND

(10) PIEZOMETER LOCATION; CIRCLED NUMBER IS PIEZOMETER NUMBER, ADJACENT NUMBER IS PIEZOMETER READING IN FEET OF WATER. 


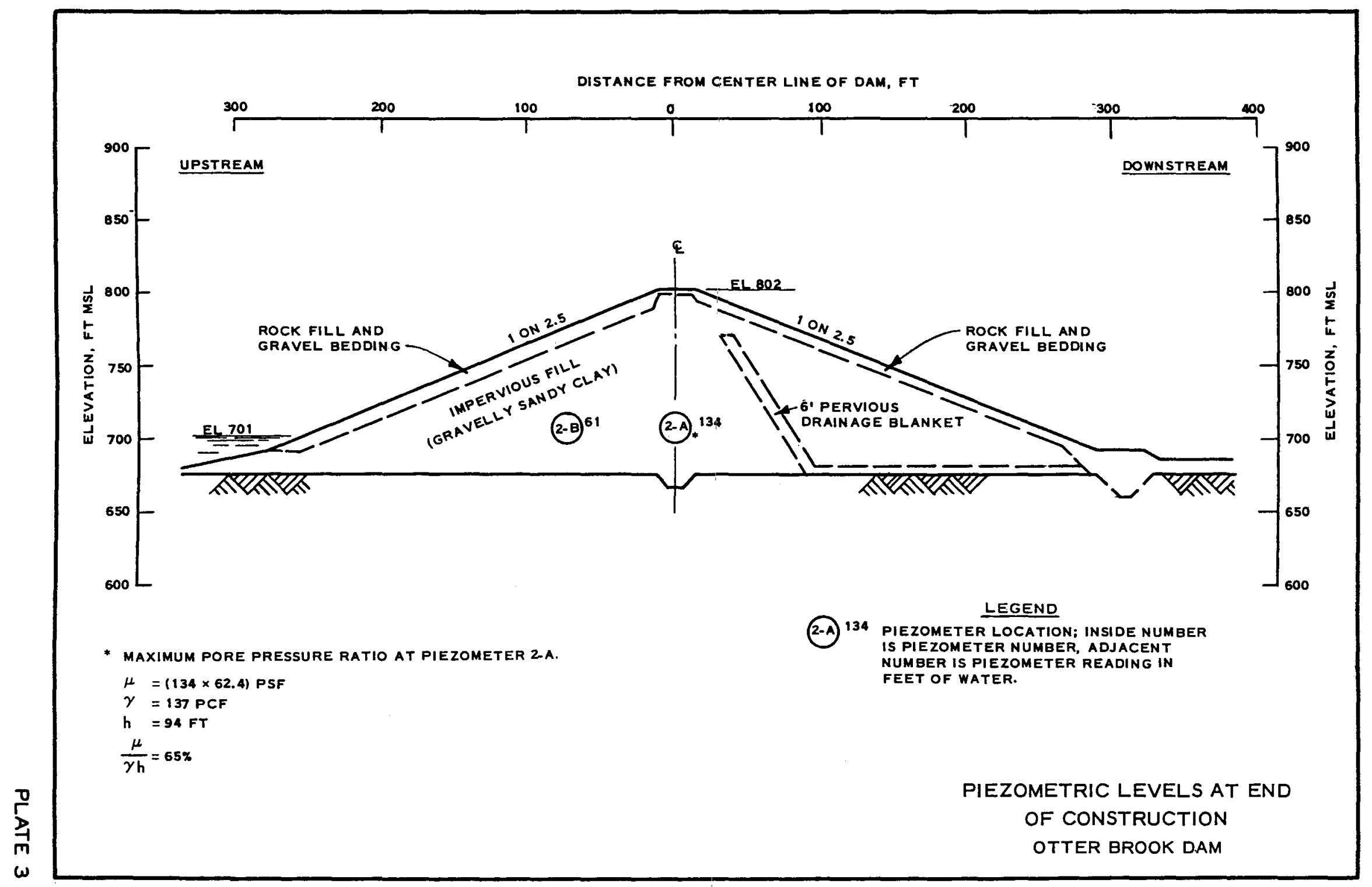




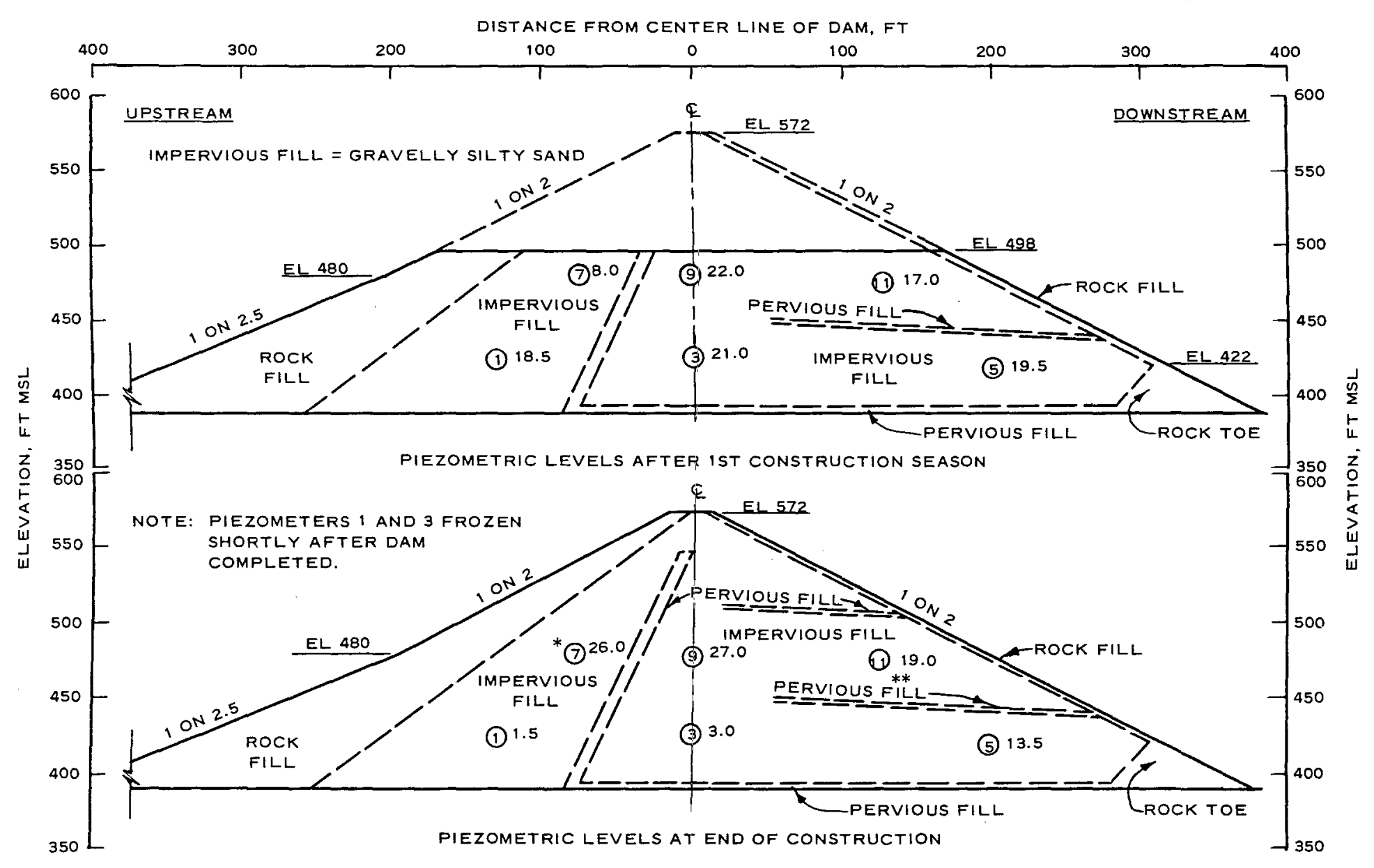

* maximum pore pressure ratio at piezometer 7. $\mu=(26 \times 62.4)$ PSF, $\gamma=144 \mathrm{PCF}, h=60 \mathrm{FT}, \frac{\mu}{\gamma h}=19 \%$

** MAXIMUM PORE PRESSURE RATIO AT PIEZOMETER 11 $\mu=(19 \times 62.4)$ PSF, $\gamma=144 \mathrm{PCF}, h=36 \mathrm{FT}, \frac{\mu}{\gamma \mathrm{h}}=23 \%$

\section{LEGEND}

(3) 3 PIEZOMETER LOCATION; INSIDE NUMBER IS PIEZOMETER NUMBER, ADJACENT NUMBER IS PIEZOMETER READING IN FEET OF WATER.
PIEZOMETRIC LEVELS AT DIFFERENT STAGES NORTH HARTLAND DAM 
DISTANCE FROM CENTER LINE OF DAM, FT

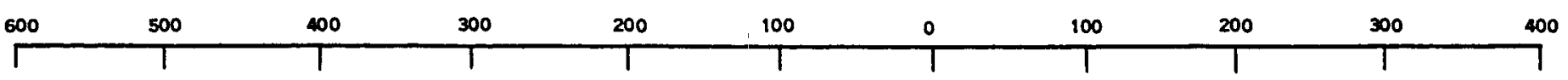

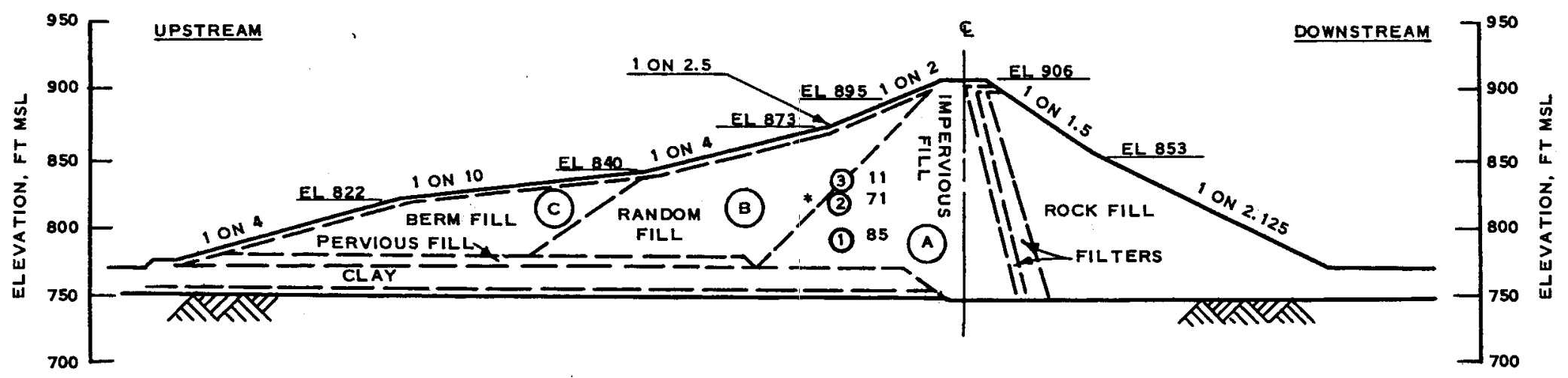

* maximum pore pressure ratio at piezometer 2.

LEGEND
$\mu=(71 \times 62.4) \mathrm{PSF}$
$\gamma=124 \mathrm{PCF}$
$h=61 \mathrm{FT}$
$\frac{\mu}{\gamma \mathrm{h}}=59 \%$
(A) = GRA VELLY CLAY
(B) = SANDY GRAVEL
(C) = SANDY GRAVEL

PIEZOMETRIC LEVELS AT END OF CONSTRUCTION

POMME DE TERRE DAM 


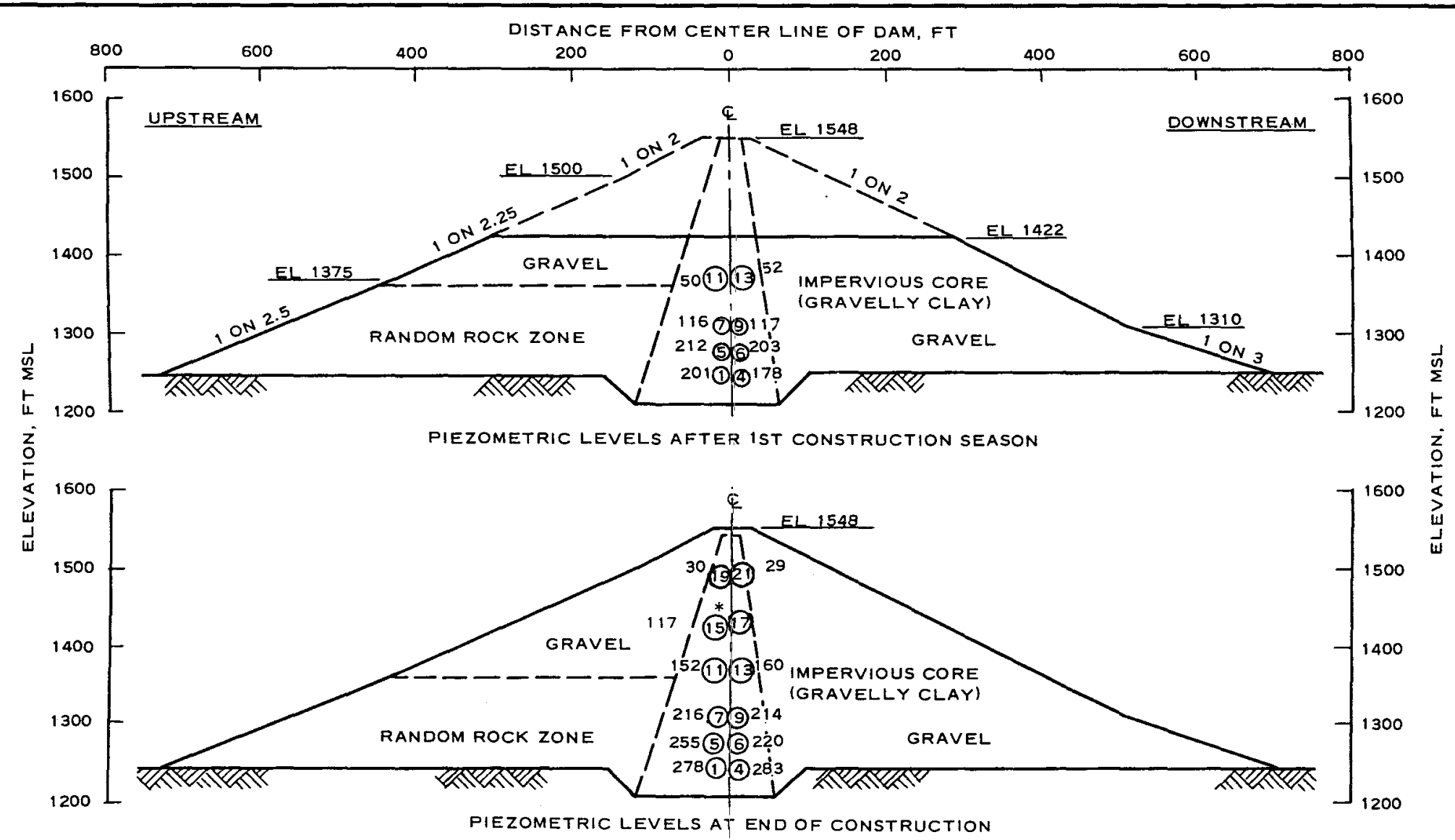

* maximum pore pressure ratio at PIEZOMETER 15.
$\mu=(117 \times 62.4) \mathrm{PSF}$
$y=133 \mathrm{PCF}$
$h=106 \mathrm{FT}$
$\frac{\mu}{y h}=52 \%$

\section{LEGEND}

(19) 30 PIEZOMETER LOCATION; INSIDE

NUMBER IS PIEZOMETER LOCATION,

ADJACENT NUMBER IS PIEZOMETER

READING IN FEET OF WATER. 


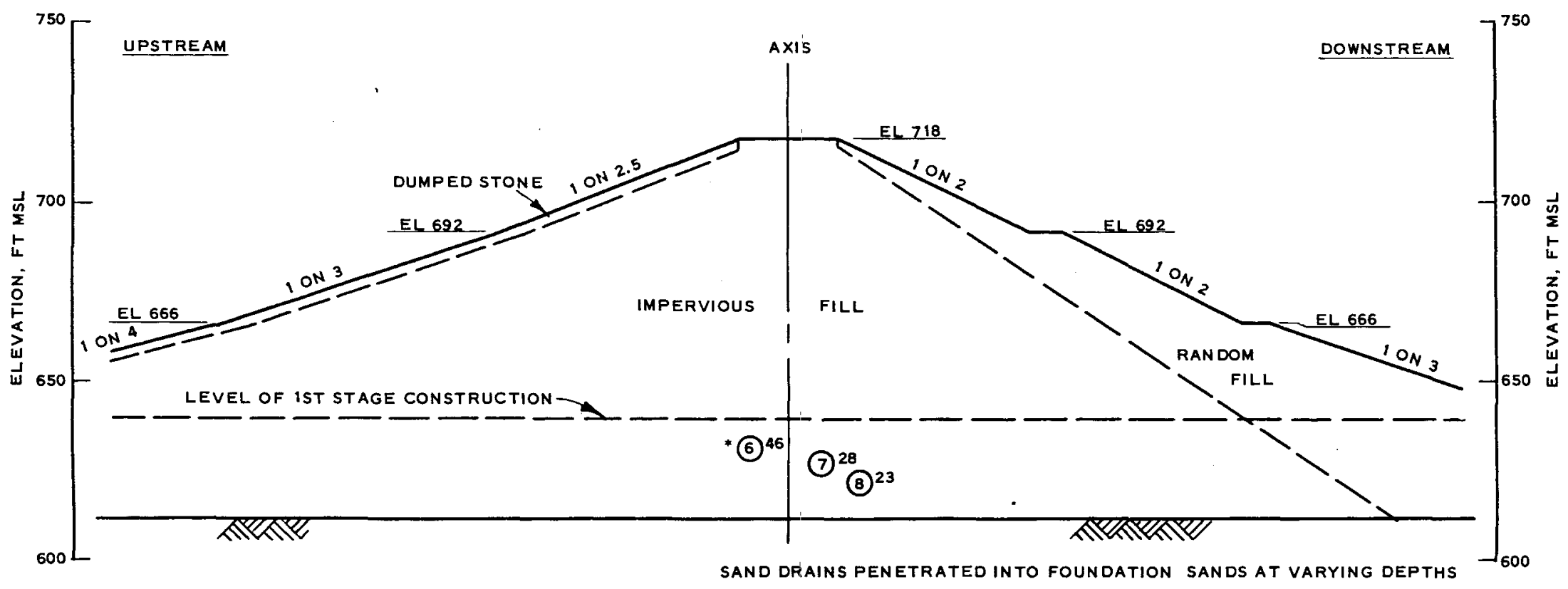

NOTE: SPACING OF SAND DRAINS AFTER IST STAGE CONSTRUCTION:

(1) PERPENDICULAR TO AXIS, DRAINS ON B. TO 12-FT C-C SPACING

(2) PARALLEL TO AXIS, DRAINS ON 8- TO 12-FT C-C SPACING

LEGEND
(8) 23 PIEZOMETER LOCATION; INSIDE NUMBER IS PIEZOMETER NUMBER, ADJACENT NUMBER IS PIEZOMETER READING IN NUMBER IS PIEZOME
FEET OF WATER.

* maximum pore pressure ratio at piezometer 6.
$\mu=(46 \times 62.4) \mathrm{PSF}$
$y=126 \mathrm{PCF}$
$h=85 \mathrm{Fr}$
$\frac{\mu}{\gamma h}=27 \%$

PIEZOMETRIC LEVELS AT END

OF CONSTRUCTION

DEWEY DAM 


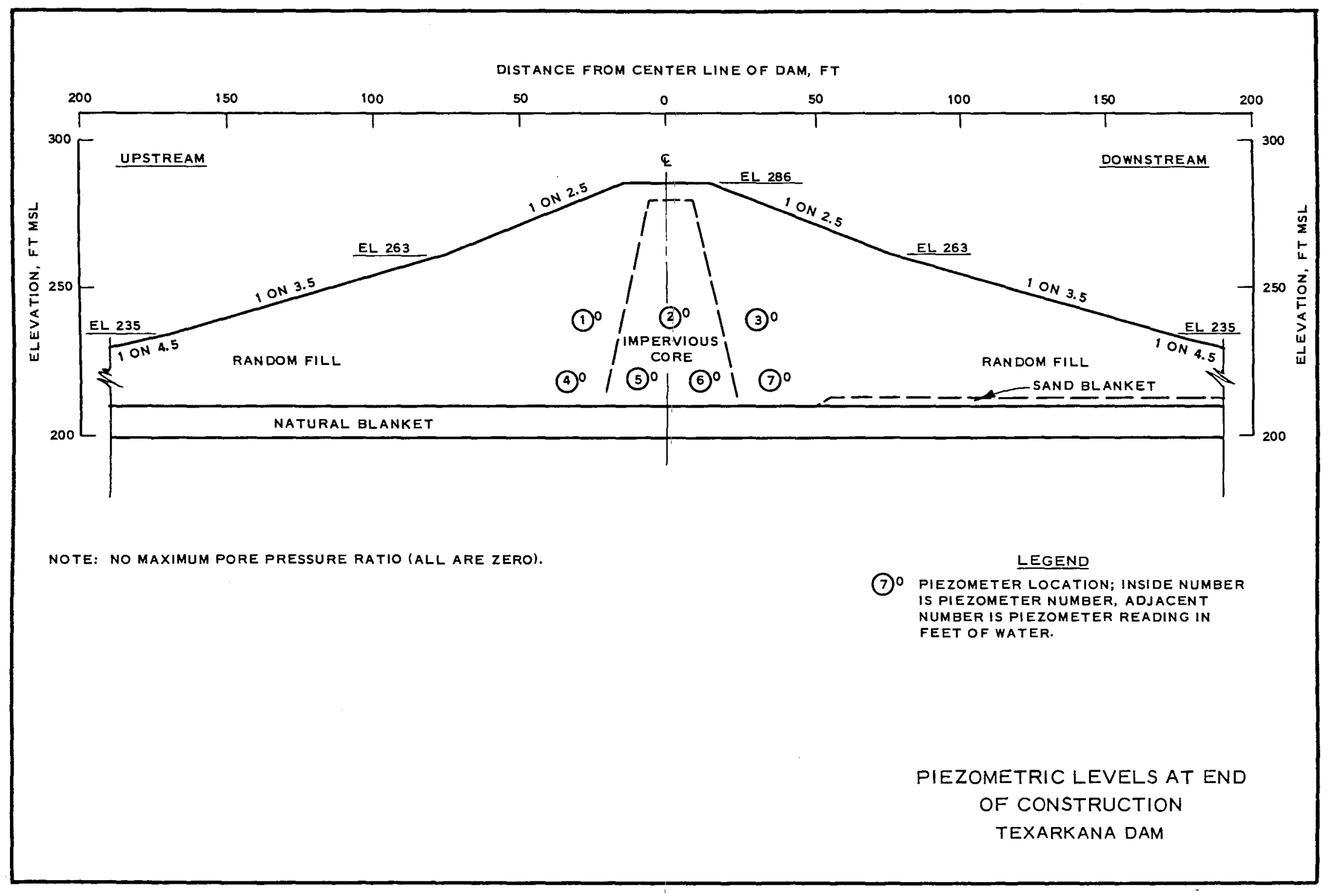




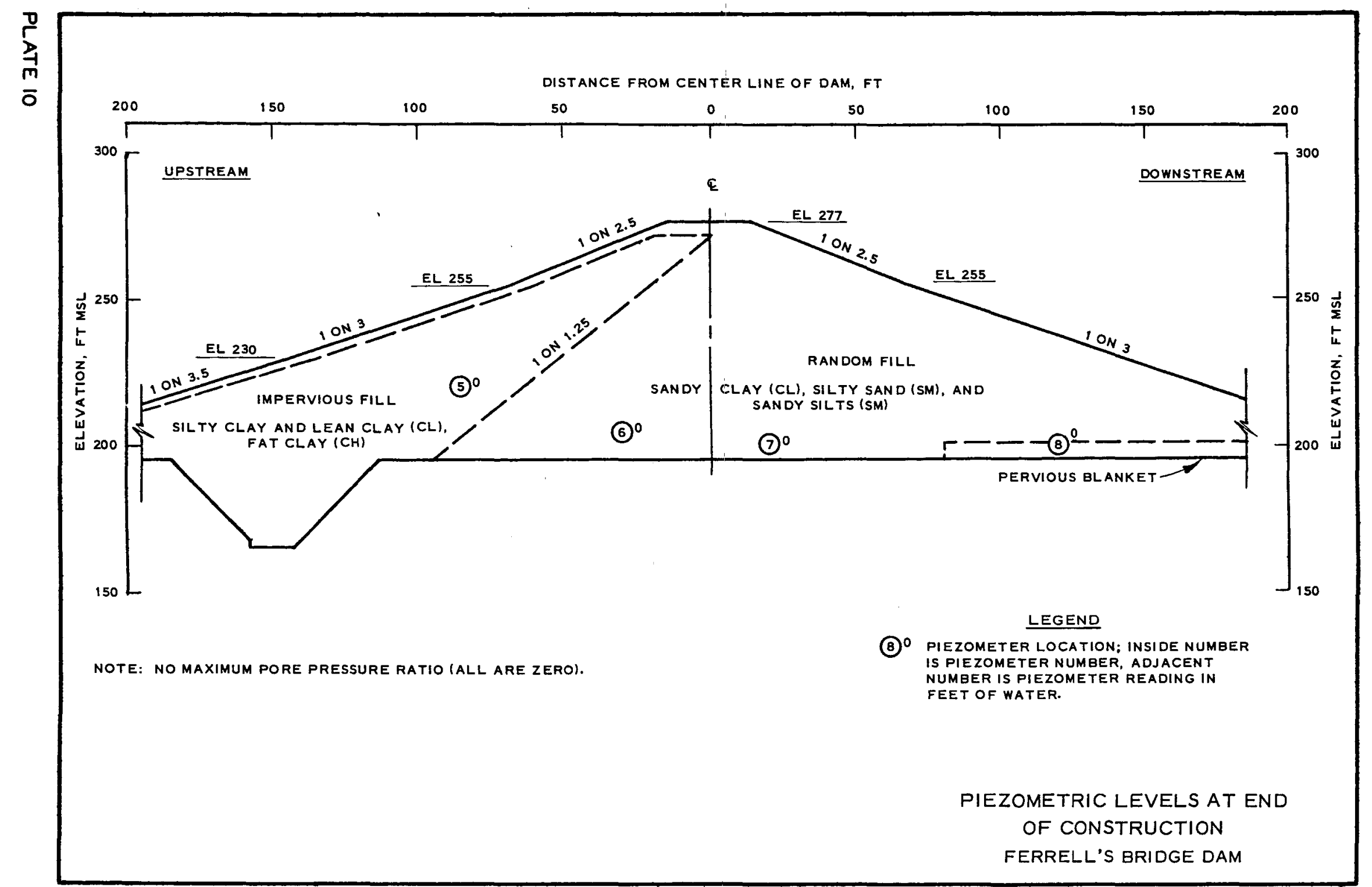


DISTANCE FROM DAM AXIS, FT

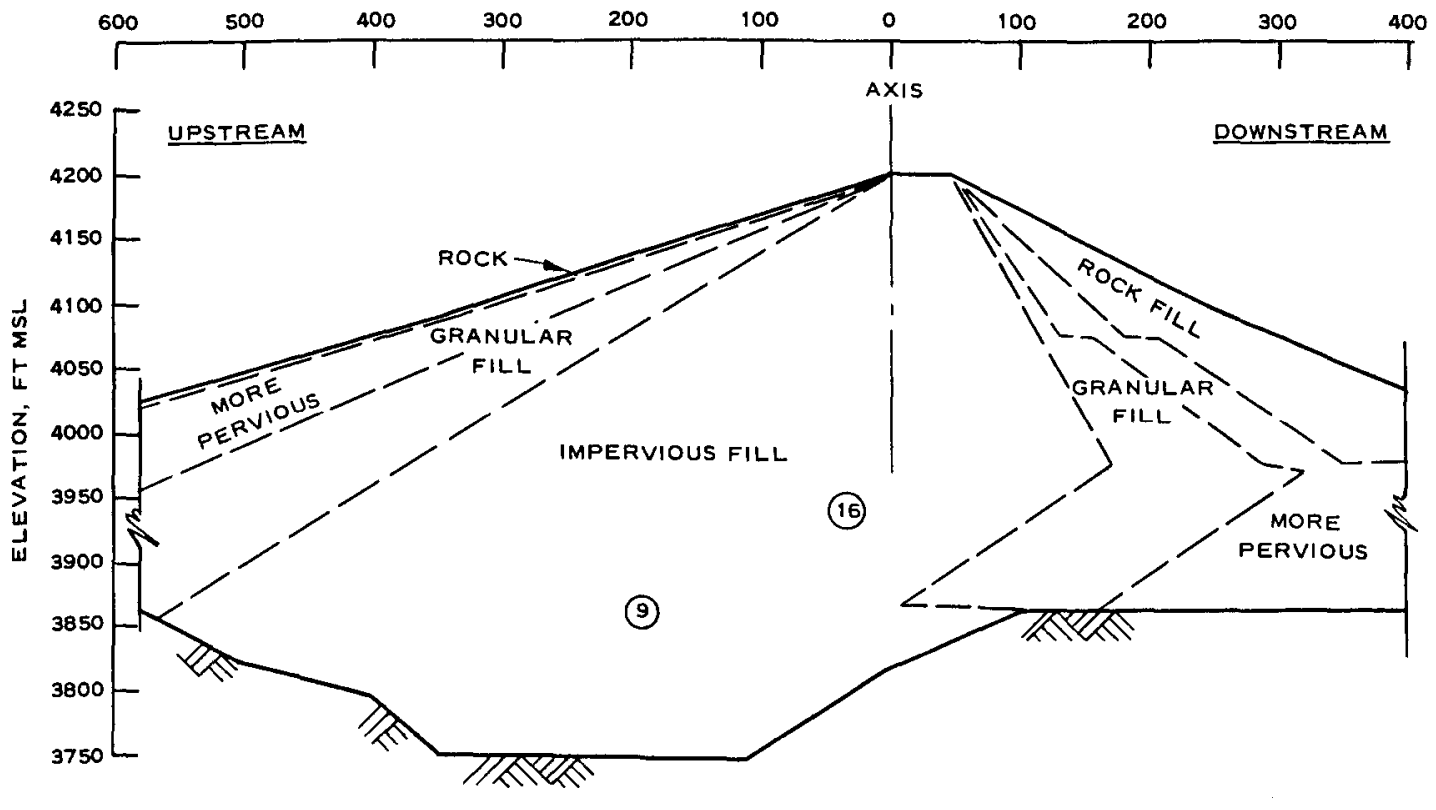

PIEZOMETER LOCATIONS

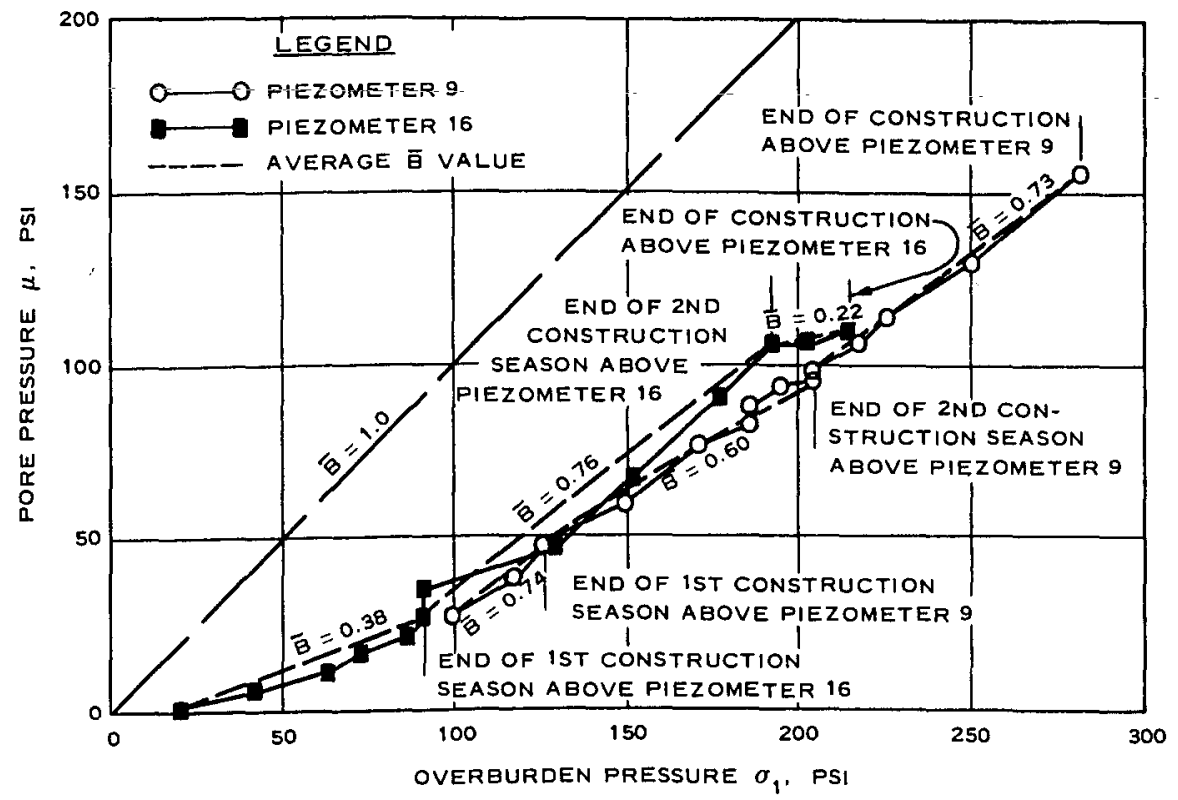

NOTE: PLOT OF $\mu$ VS $\sigma_{1}$ COVERS THREE CONSTRUCTION

PERIODS FOR BOTH PIEZOMETERS (SEE TABLE 4).

\author{
PLOT OF $\mu$ VS $\sigma_{1}$ \\ ANDERSON RANCH DAM
}




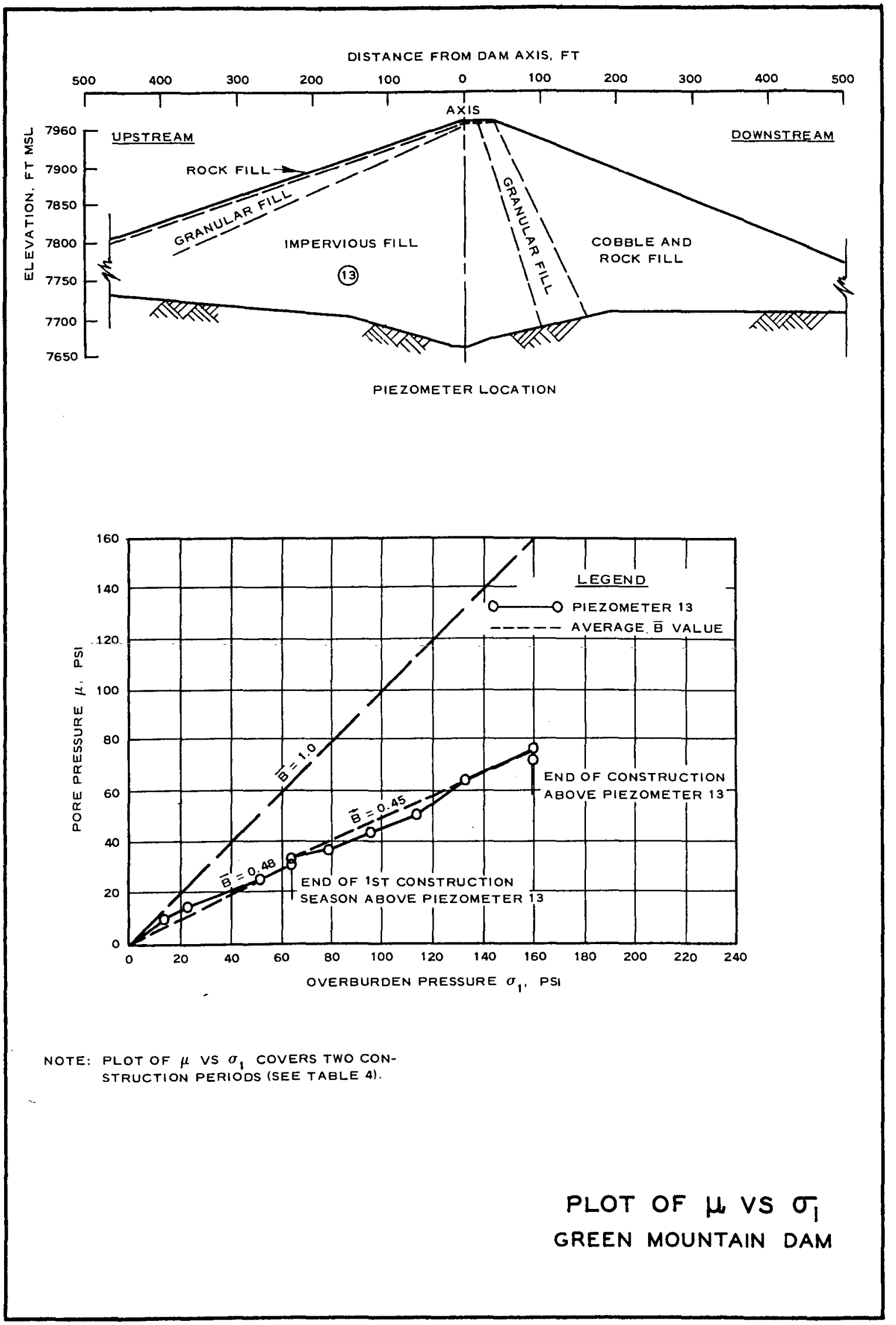




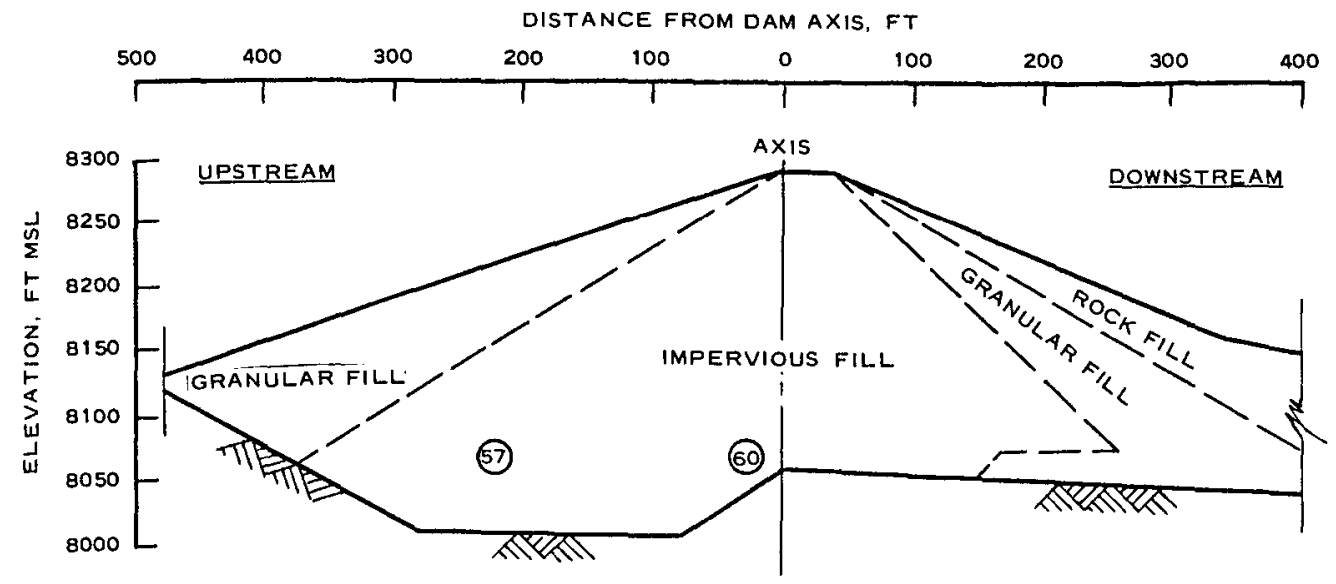

PIEZOMETER LOCATIONS

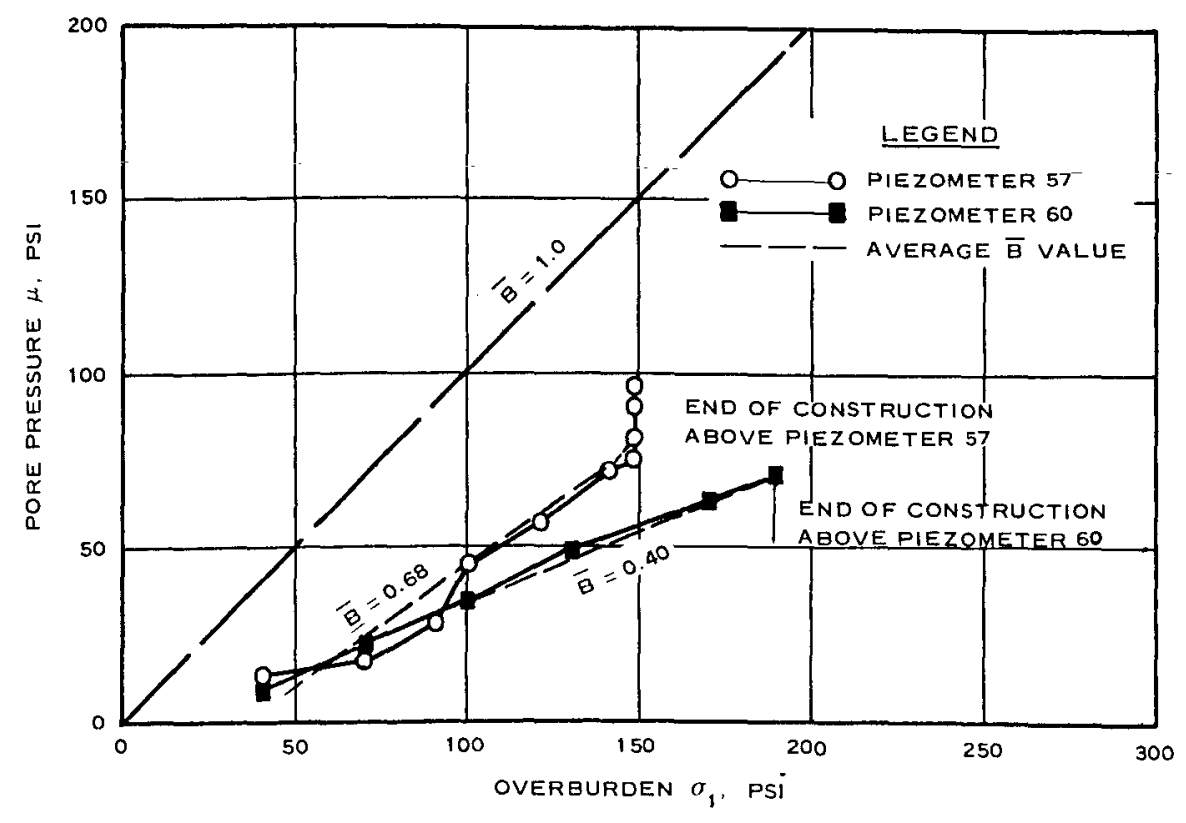

NOTE: PLOT OF $\mu$ VS $\sigma$, FOR BOTH PIEZOMETERS COVERS THE PERIOD OF ONE CONSTRUCTION SEASON (SEE TABLE 4). 
DISTANCE FROM DAM AXIS, FT

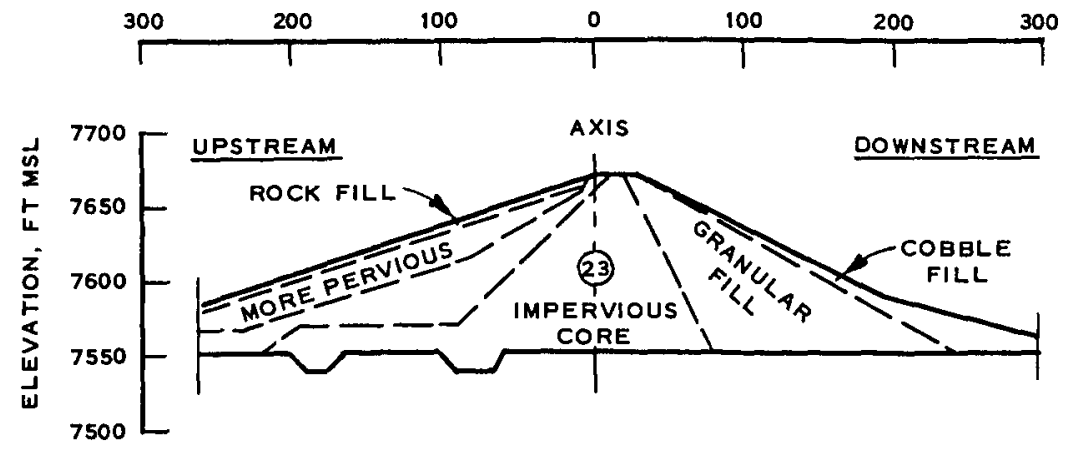

PIEZOMETER LOCATION

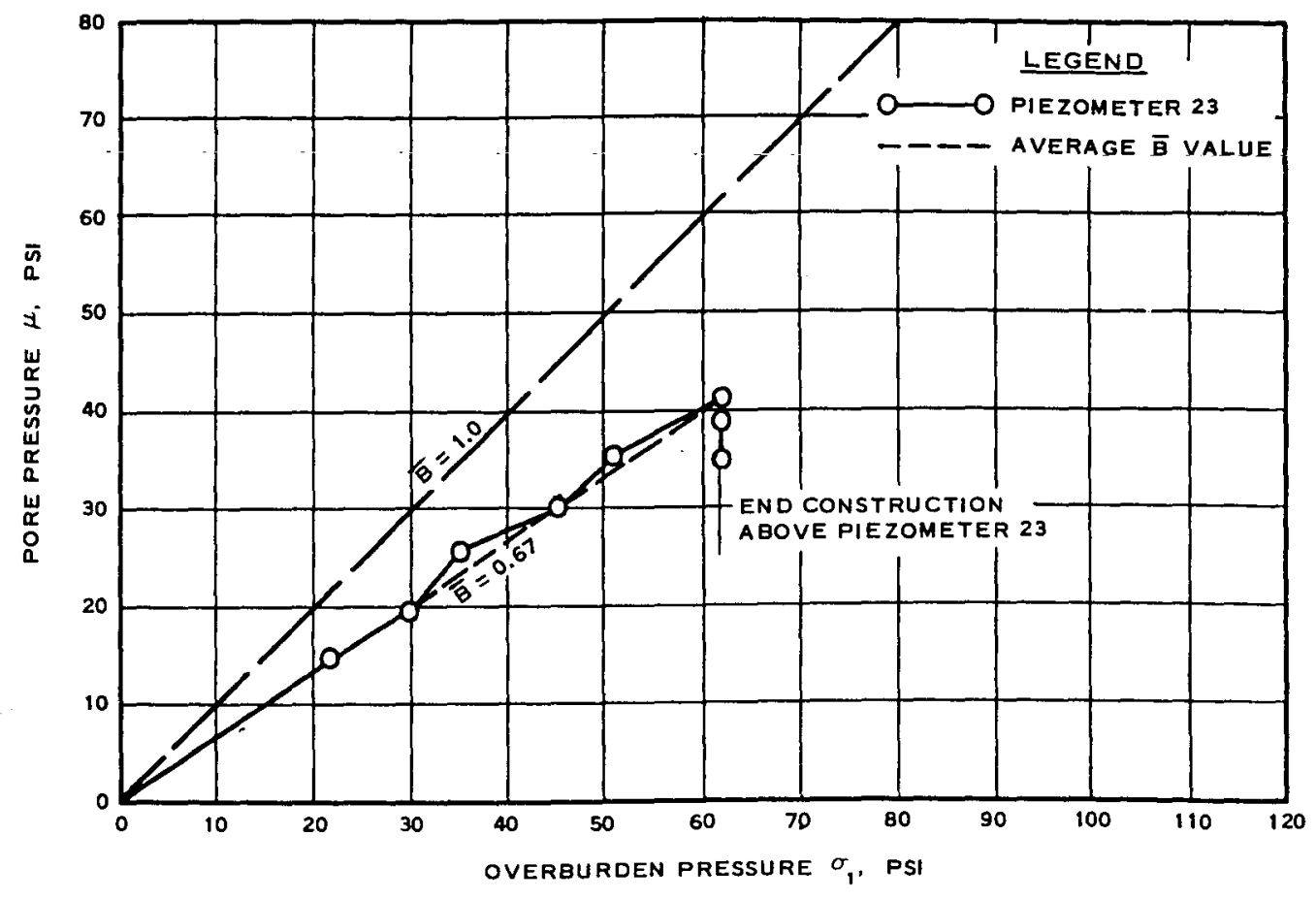

NOTE: PLOT OF $\mu$ VS $\sigma_{1}$ COVERS THE PERIOD

OF ONE CONSTRUCTION SEASON (SEE

TABLE 4). 

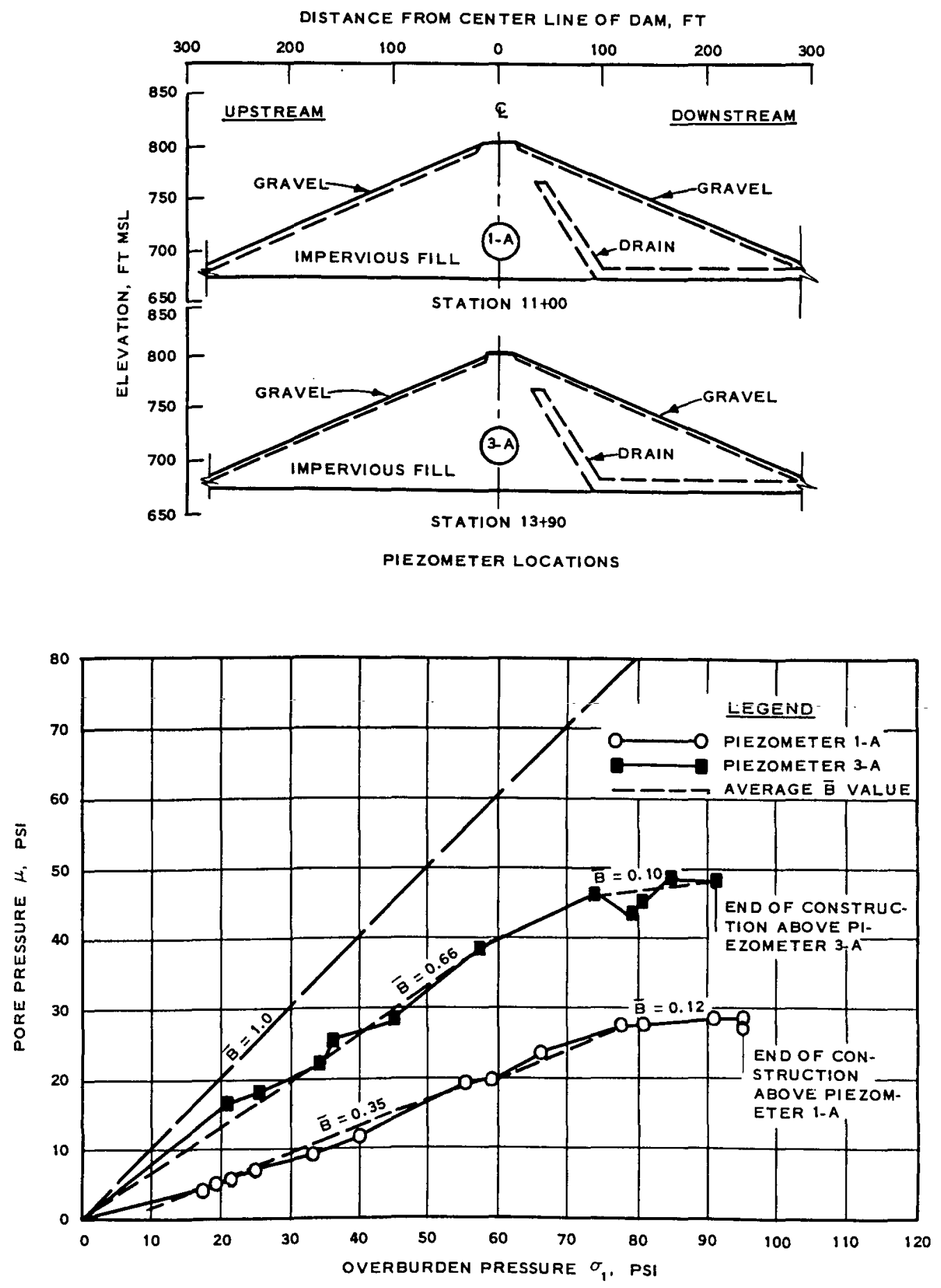

NOTE: PLOT OF $\mu$ VS $\sigma$, FOR BOTH PIEZOMETERS COVERS THE PERIOD OF ONE CONSTRUCTION SEASON (SEE TABLE 4). 
DISTANCE FROM CENTER LINE OF DAM, FT

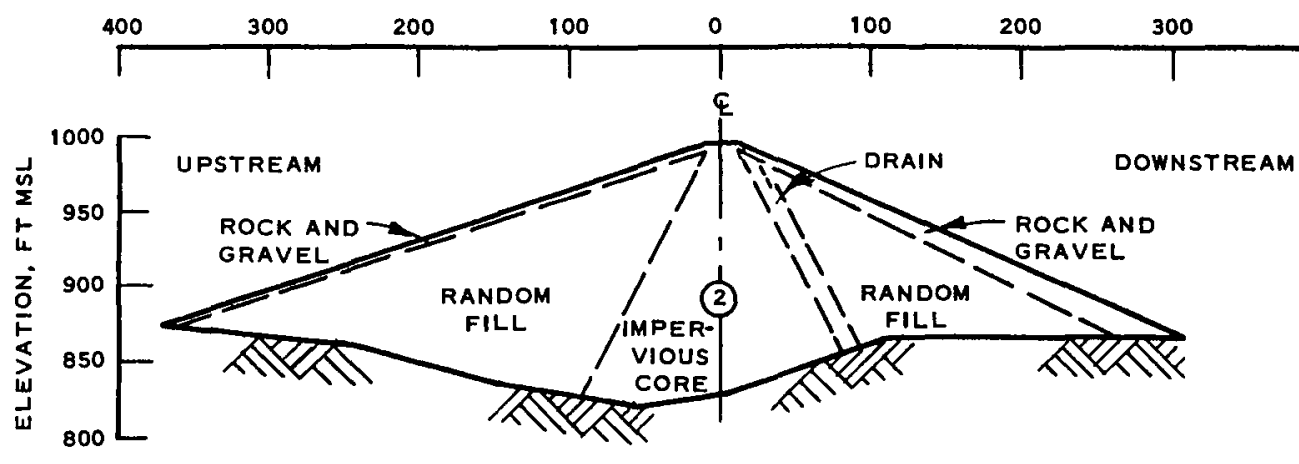

PIEZOMETER LOCATION

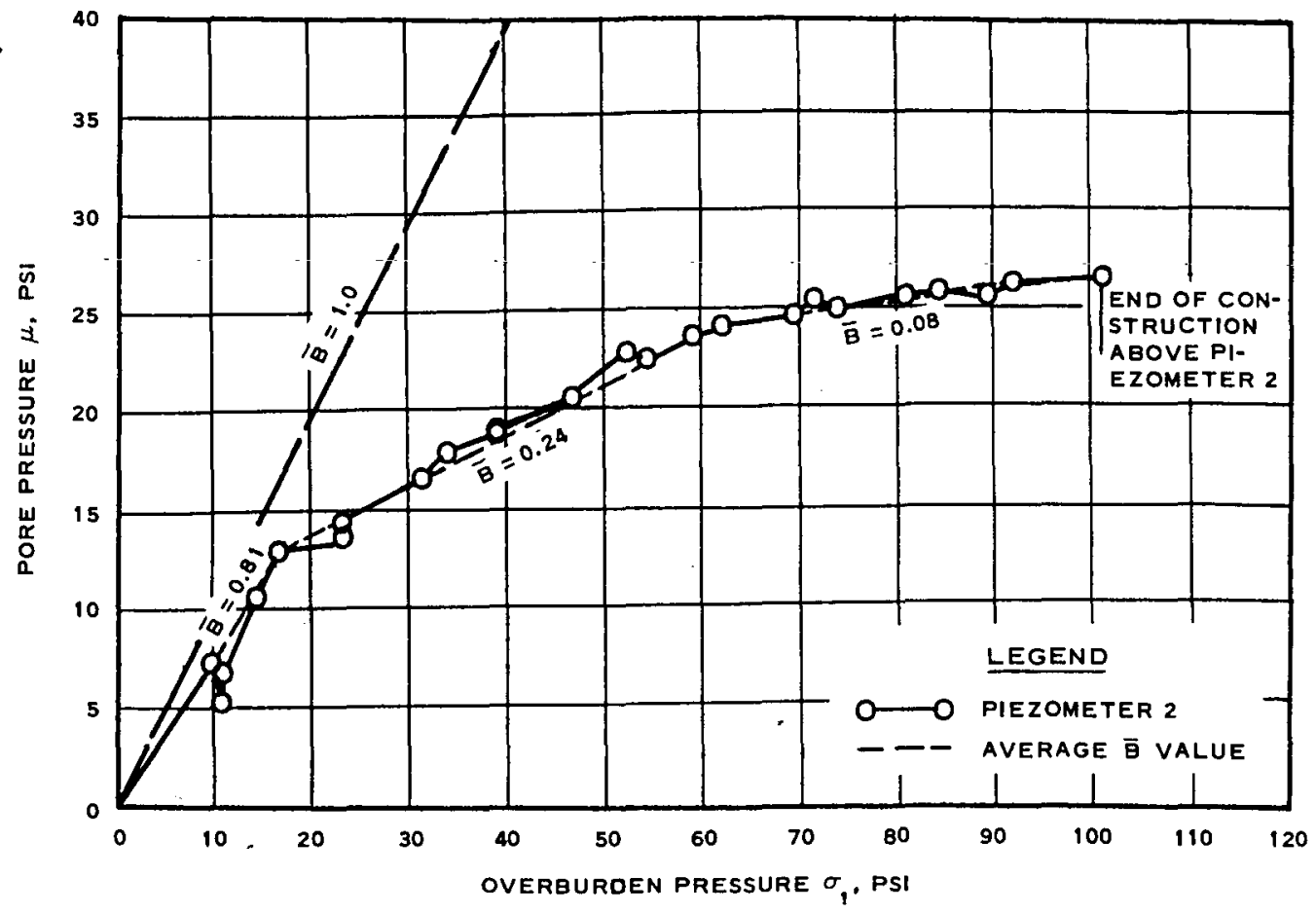

NOTE: PLOT OF $\mu$ VS $\sigma$, COVERS ONE CON-

STRUCTION PERIOD (SEE TABLE 4).

\author{
PLOT OF $\mu$ VS $\sigma_{1}$ \\ MAD RIVER DAM
}




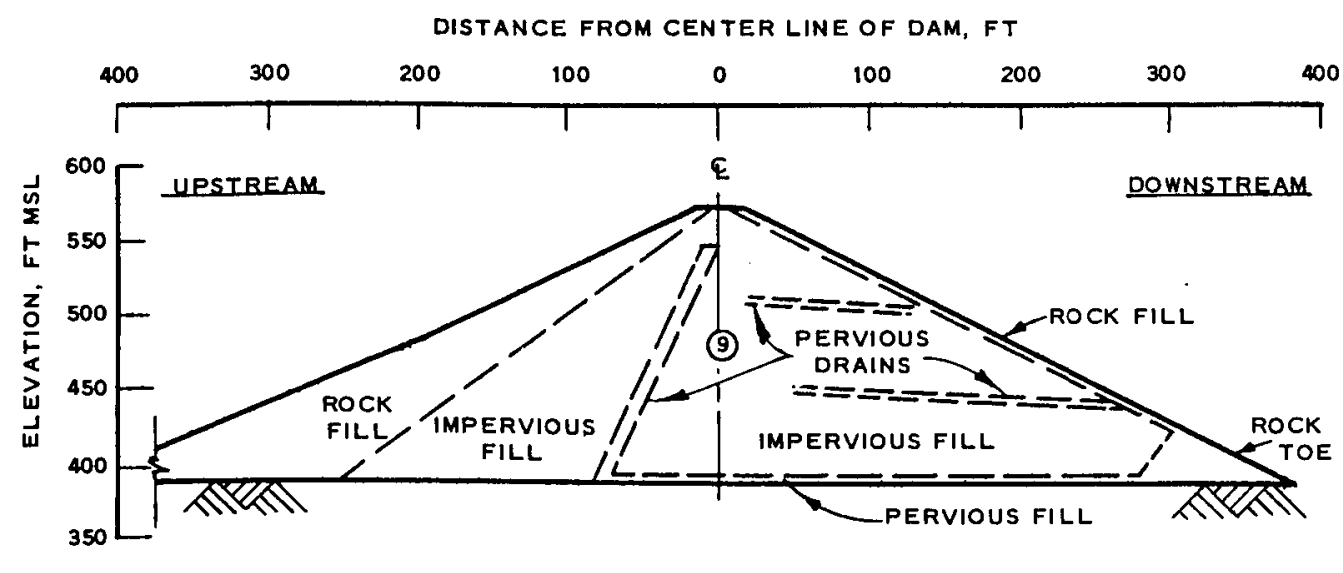

PIEZOMETER LOCATION

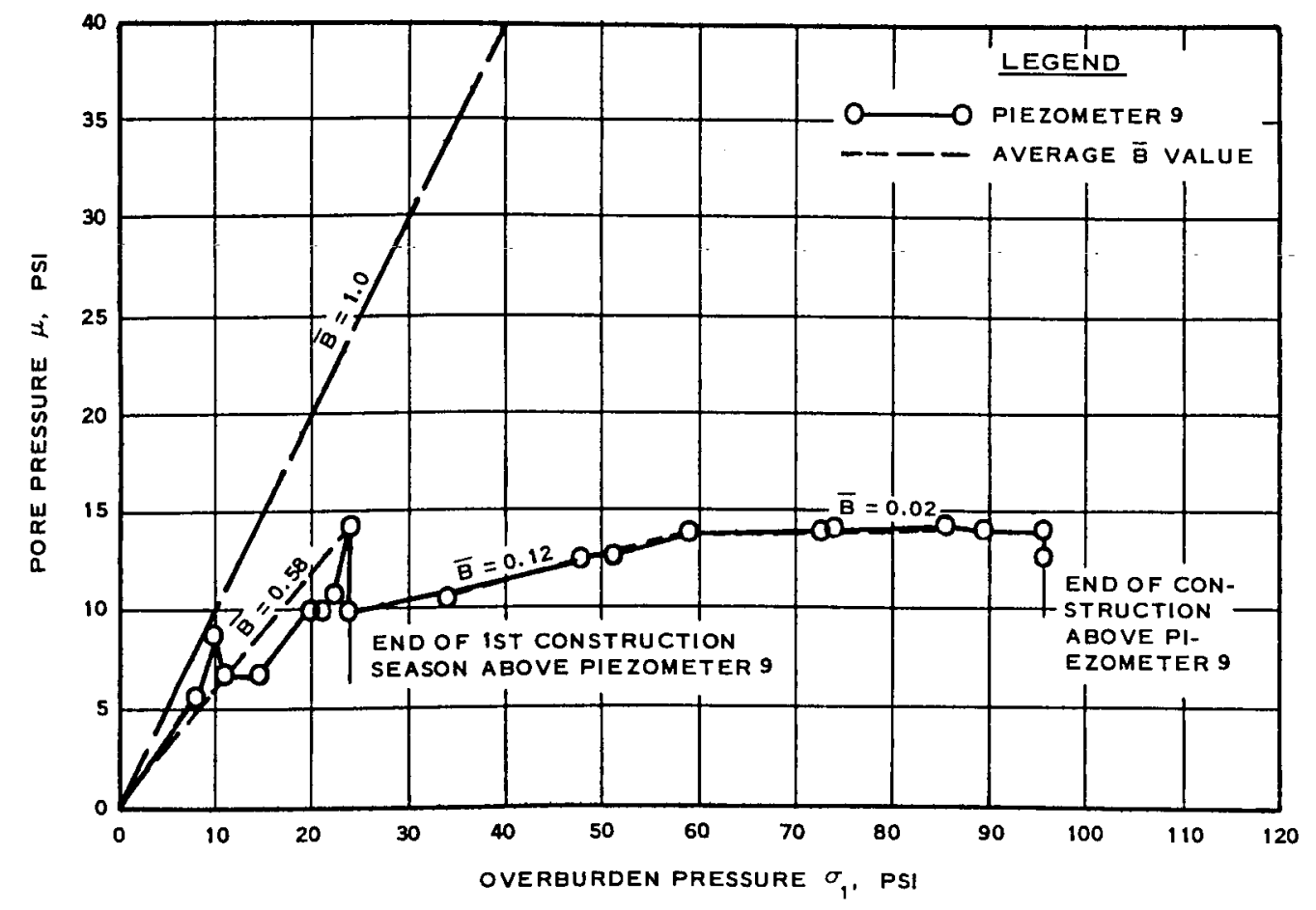

NOTE: PLOT OF $\mu$ VS $\sigma_{1}$ COVERS TWO CON-

STRUCTION PERIODS (SEE TABLE 4).

PLOT OF $\mu$ VS $\sigma_{1}$ NORTH HARTLAND DAM 
DISTANCE FROM CENTER LINE OF DAM, FT

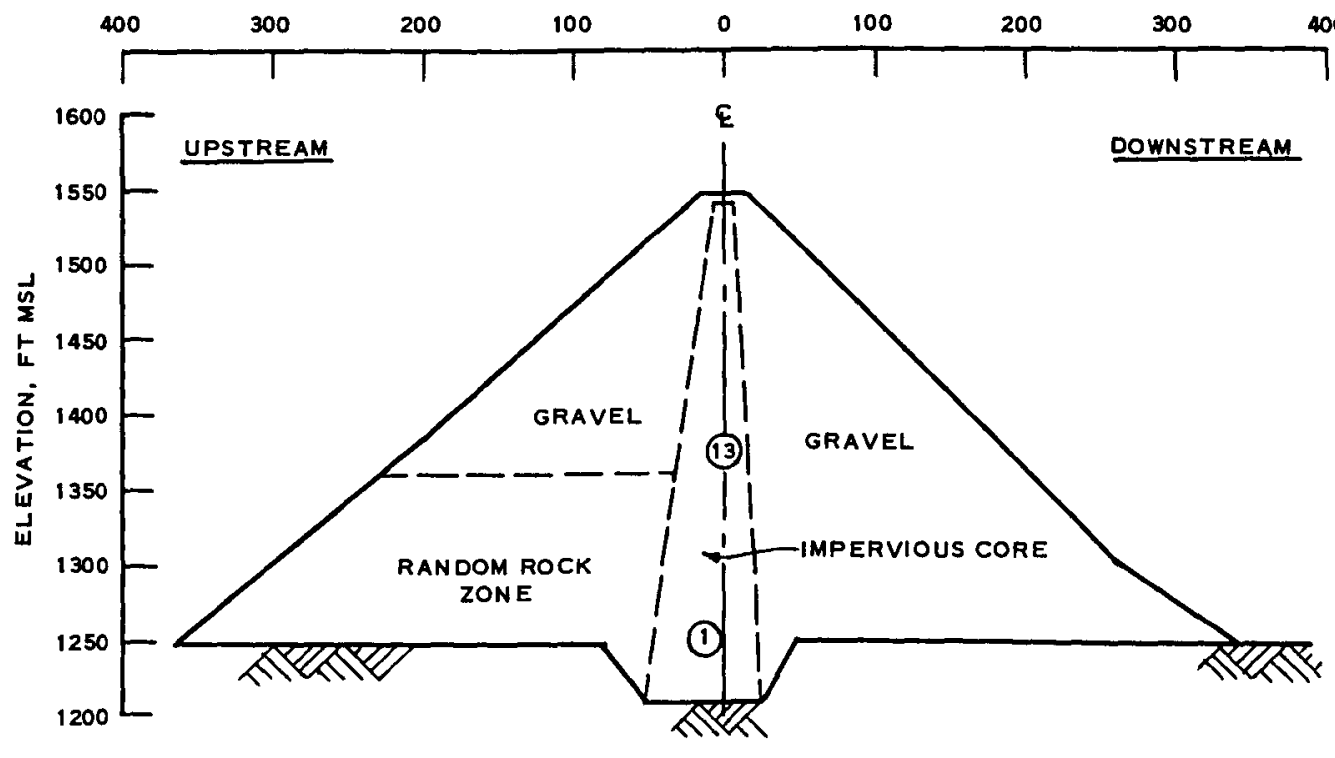

PIEZOMETER LOCATIONS

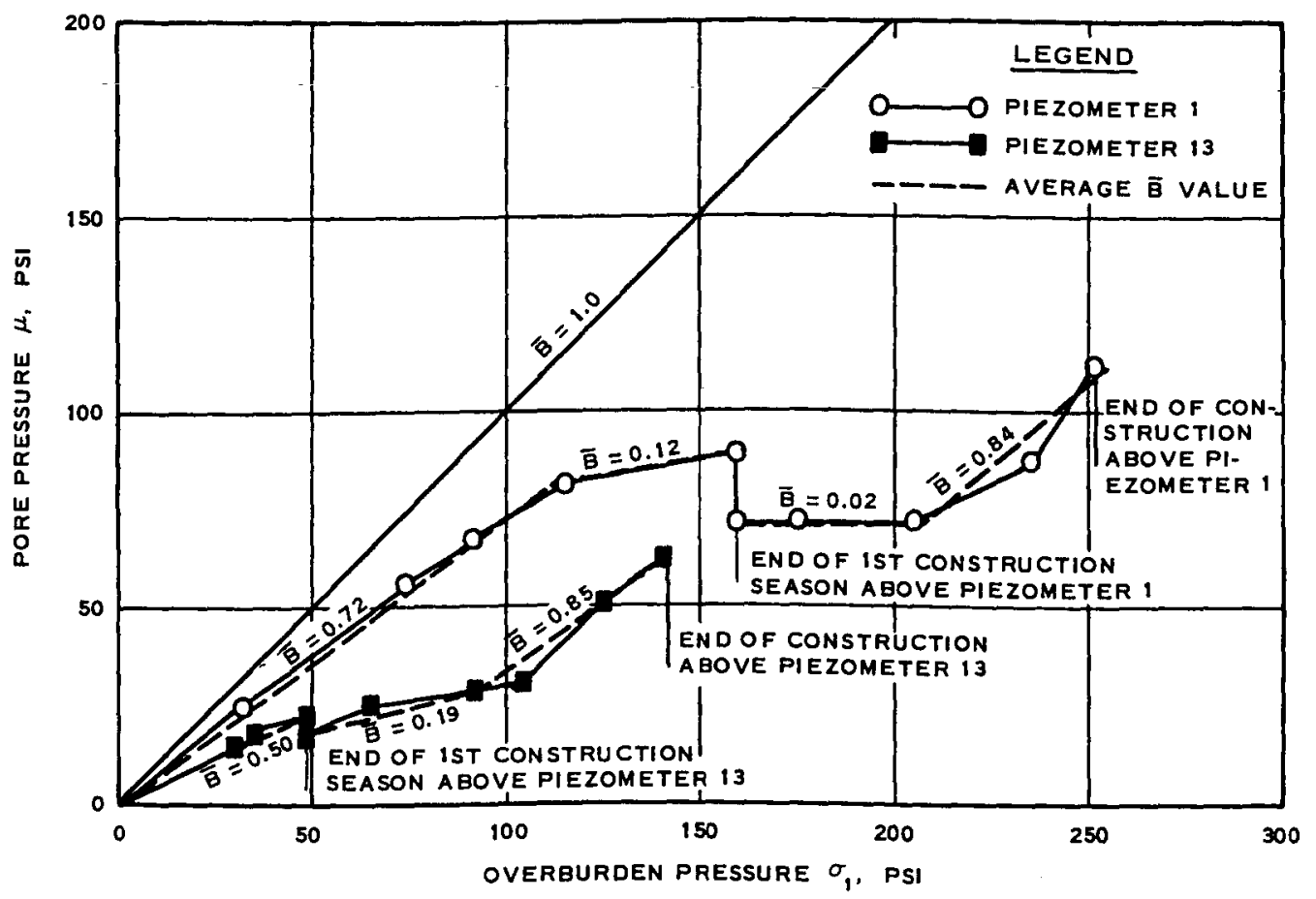

NOTE: PLOT OF $\mu$ VS $\sigma_{1}$ COVERS TWO CON-

STRUCTION PERIODS FOR BOTH

PIEZOMETERS (SEE TABLE 4).

PLOT OF $\mu$ VS $\sigma_{1}$

HILLS CREEK DAM 


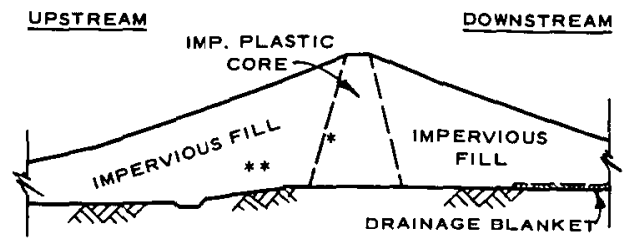

TAELE ROCK DAM

MAXIMUM PORE PRESSURE RATIO, $\frac{\mu}{\gamma h}$

* in CORE (ASSUMED) $=51 \%$

** in DAM (MEASURED) $=62 \%$

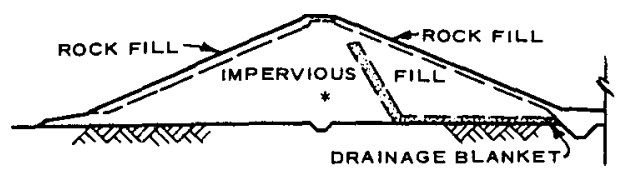

OTTER BROOK DAM

* measured maximum pore pressure ratio, $\frac{\mu}{\gamma h}=65 \%$

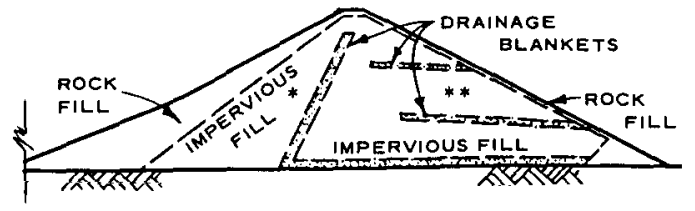

\section{NORTH HARTLAND DAM}

MAXIMUM PORE PRESSURE RATIO, $\frac{\mu}{y h}$

* MEASURED $=23 \%$

** MEASURED $=19 \%$

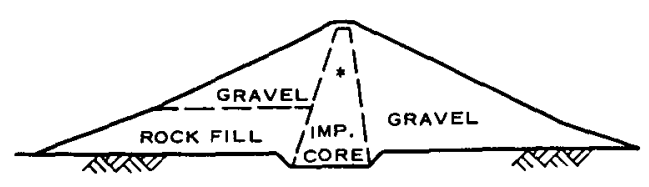

HILLS CREEK DAM

* measured maximum pore pressure ratio, $\frac{\mu}{y h}=52 \%$

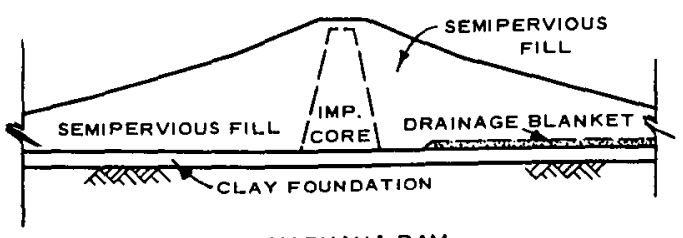

TEXARKANA DAM

NOTE: NO PORE PRESSURES.
UPSTREAM DOWNSTREAM

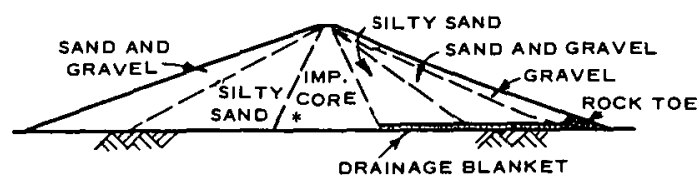

旦AKELYMT.DAM

* measured maximum pore pressure ratio, $\frac{\mu}{\gamma h}=10 \%$

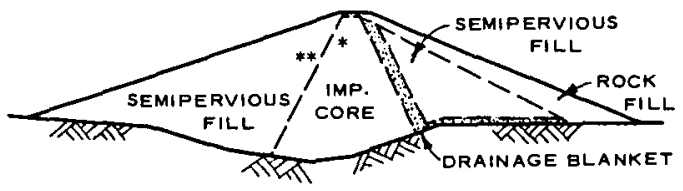

MAD RIVER DAM

MAXIMUM PORE PRESSURE RATIO, $\frac{\mu}{\gamma h}$

* IN CORE (ASSUMED) $=44 \%$

** IN dam (Measured) $=40 \%$

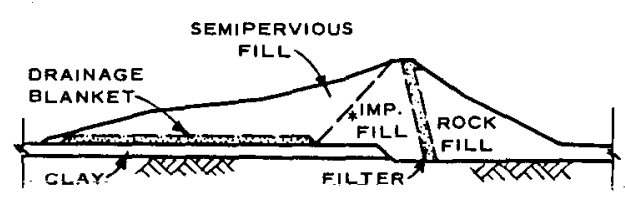

POMME DE TERRE DAM

* measured maximum pore pressure. $\frac{\mu}{\gamma h}=59 \%$

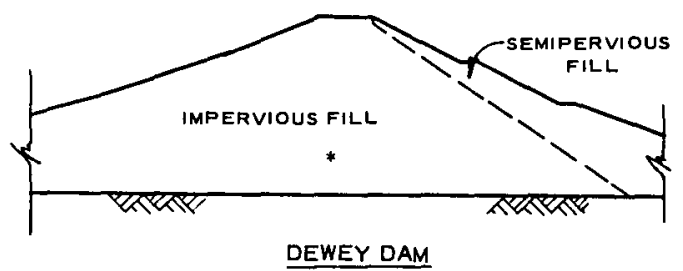

NOTE: SAND DRAINS ON $10 \mathrm{FT} \pm 2$ FT C-C. THROUGHOUT DAM, EXTEND INTO FOUNDATION.

* measured maximum pore pressure ratio. $\frac{\mu}{\gamma h}=27 \%$

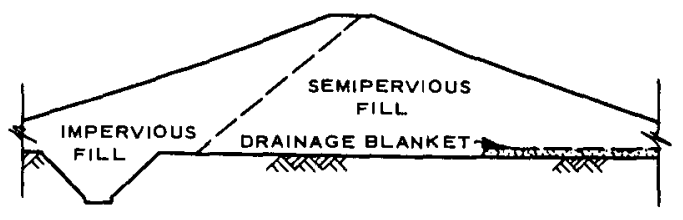

FERRELL'S BRIDGE DAM

NOTE: NO PORE PRESSURES.

MAXIMUM PORE PRESSURE RATIOS IN CE DAMS 
APPENDIX A

\section{WES MULTIPIE IETTER}


SUBJECT: Embankment Pore Pressure Data, CWI 531

TO:
Division Engineer, USAE Division, Missouri River, Omaha, Nebr. Division Engineer, USAE Division, New England, Waltham, Mass. Division Engineer, USAE Division, North Central, Chicago, I11. Division Engineer, USAE Division, North Pacific, Portland, Ore. Division Engineer, USAE Division, Ohio River, Cincinnati, Ohio Division Engineer, USAE Division, South Atlantic, Atlanta, Ga. Division Engineer, USAE Division, South Pacific, San Francisco, Calif.
Division Engineer, USAE Division, Southwestern, Dallas, Tex. ATTN: Chief, Engineering Division

1. Reference is made to our multiple letter dated 14 January 1963, subject "Foundation Pore Pressures Beneath Embankments, CWI 531." At the request of the Office, Chief of Engineers, the scope of this project has been enlarged to include the study of pore pressure data from measuring devices located within earth embankments. Therefore, it is requested that you furnish available observational data of this nature for earth dams in your division which have not previously been furnished this office.

2. The following information is specifically desired:

a. Cross sections of the embankment indicating zonations and showing the locations of the piezometer installations.

b. Description of foundation soils and stratification.

c. Description of the embankment soils in the various zones as placed, including data on placement water contents, densities, and compaction; shear strength and consolidation tests; and placement procedures, including water content control.

d. Details of the installations, including types of devices used (open- or closed-system piezometers, hydrostatic pressure cells), types of piezometer tips, filters, tip elevations, and installation procedures.

e. Time plots of fill height and pore pressures at the piezometer locations and concurrent plots of reservoir levels. measurements.

f. Stability analyses based on the results of the pore pressure 
SUBJECT: Embankment Pore Pressure Data, CWI 531

3. We would appreciate your furnishing this information by 3 September 1963 or earlier, if possible.

FOR THE DIRECTOR:

\author{
A. A. MAXWELL \\ Engineer \\ Acting Chief, Soils Division
}

Copies furnished:

Mr. R. I. Kaufman, IMVD

OCE (ENGCW-ES) 
Table Al

Embankment Pore Pressure Study

Division Offices Response to WES Letter of 28 June 1963

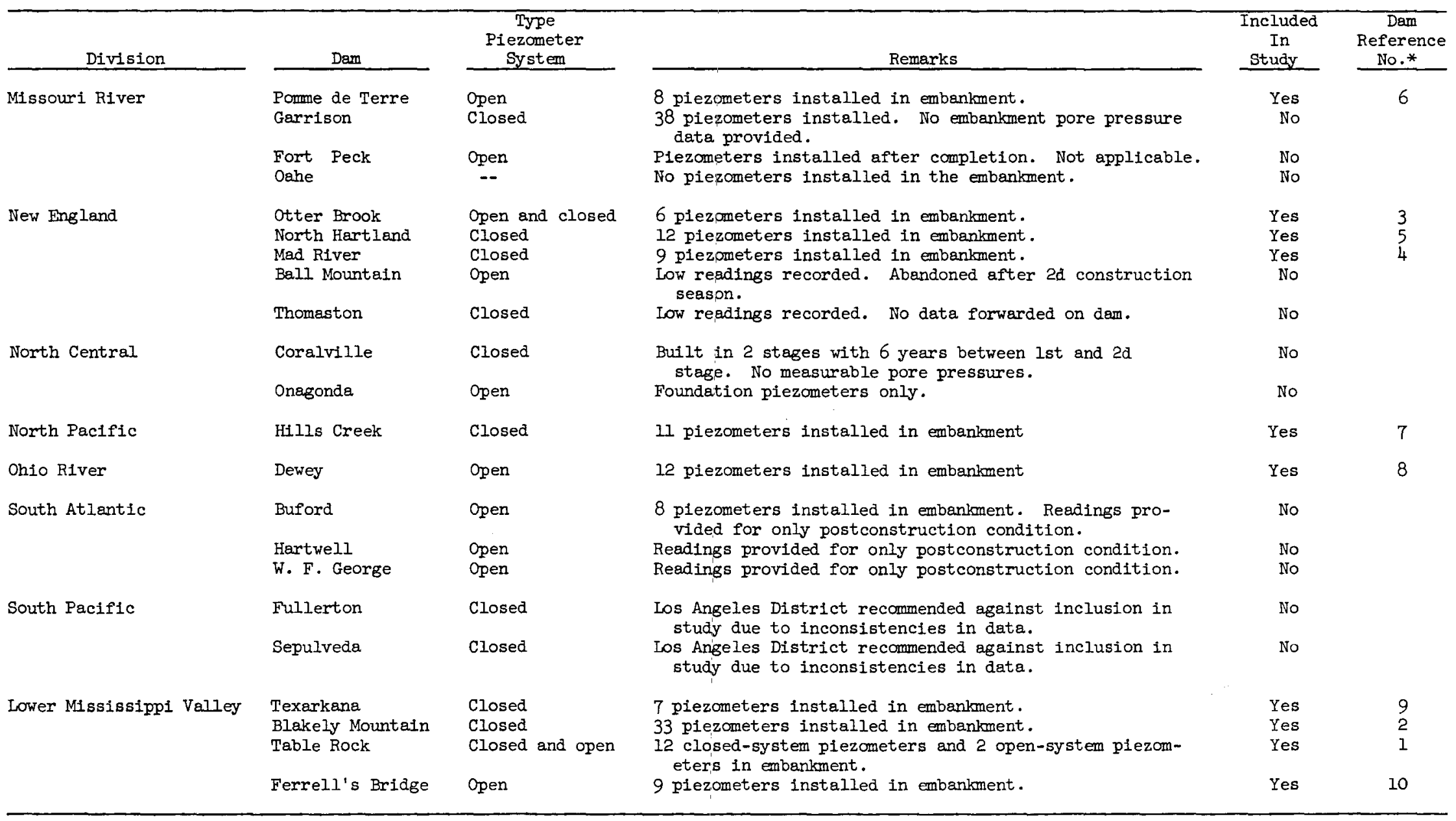

Note: There was no response by Southwestern Division to the WES letter, and through oversight, WES failed to follow up.

* See table 1 of main report. 
APPENDIX B

PIEZOMETER SYSTEMS OF EARTH DAMS USED IN THIS STUDY 
Table BI

Piezometer Systems of Dams Used in Study

\begin{tabular}{|c|c|c|c|c|}
\hline $\begin{array}{c}\text { Dam } \\
\text { Reference } \\
\text { No.** } \\
\end{array}$ & Dam & Location & $\begin{array}{c}\text { Type } \\
\text { Piezometer } \\
\text { System }\end{array}$ & $\begin{array}{c}\text { Piezometer } \\
\text { Tip } \\
\text { Type** } \\
\end{array}$ \\
\hline 1 & Table Rock & Ark. & Closed and open & Ia and Ib \\
\hline 2 & Blakely Mountain & Ark. & Closed and open & Ia and $\mathrm{Ib}$ \\
\hline 3 & Otter Brook & N. $\mathrm{H}$. & Closed & $\mathrm{J}$ \\
\hline 4 & Mad River & Conn. & Closed & $\mathrm{J}$ \\
\hline 5 & North Hartland & Vt. & Closed & $J$ \\
\hline 6 & Pomme de Terre & Mo. & Open & I \\
\hline 7 & Hills Creek & Oreg. & Open & K \\
\hline 8 & Dewey & $\mathrm{Ky} \cdot$ & Open & $\mathrm{E}$ \\
\hline 9 & Texarkana & Tex. & Closed & M \\
\hline 10 & Ferrell's Bridge & Tex. & Open & $\mathrm{N}$ \\
\hline 11 & Anderson Ranch & Idaho & Closed & $\mathrm{A}$ and $\mathrm{C}$ \\
\hline 12 & Green Mountain & Colo. & Closed & C \\
\hline 13 & Granby & Colo. & Closed & $\mathrm{C}$ \\
\hline 14 & Davis & Ariz. & Closed & $\mathrm{C}$ \\
\hline 15 & O'Sullivan & Wash. & Closed & $\mathrm{C}$ \\
\hline 16 & Spring Canyon & Colo. & Closed & $\mathrm{C}$ \\
\hline 17 & Boysen & Wyo. & Closed & $\mathrm{C}$ \\
\hline 18 & Jackson Gulch & Colo. & Closed & C \\
\hline 19 & Cedar Bluff & Kans. & Closed & C \\
\hline 20 & Deer Creek & Utah & Closed & $\mathrm{B}$ \\
\hline 21 & Alcova & Wyo. & Closed & -- \\
\hline 22 & North Coulee & Wash. & CIosed & $\mathrm{C}$ \\
\hline 23 & Vallecito & Colo. & Closed & B \\
\hline 25 & Shade Hill & S. Dak. & Closed & $\mathrm{C}$ \\
\hline 25 & Bonny & Colo. & Closed & C \\
\hline 26 & Grassy Lake & Wyo. & Closed & -- \\
\hline 27 & Medicine Creek & Nebr. & Closed & $\mathrm{C}$ \\
\hline 28 & Heart Butte & N. Dak. & Closed. & $\mathrm{C}$ \\
\hline 29 & Long Lake & Wash. & Closed & $\mathrm{C}$ \\
\hline 30 & Enders & Nebr. & Closed & C \\
\hline 31 & Caballo & N. Mex. & Closed & -- \\
\hline 32 & Island Park & Idaho & Closed & -- \\
\hline 33 & Fresno & Mont. & Closed & $\mathrm{B}$ \\
\hline 34 & Hor setooth & Colo. & Closed & $\mathrm{C}$ \\
\hline 35 & Castiletto & Switzerland & -- & -- \\
\hline 36 & Rosshaupton & Germany & $\begin{array}{l}\text { Electrical } \\
\text { transmitters }\end{array}$ & -- \\
\hline 37 & Usk & Wales & Closed & $\mathrm{D}$ \\
\hline 38 & Sasumua & Kenya & Closed & $\mathrm{D}$ \\
\hline 39 & Knockendon & Scotland & Open & -- \\
\hline 40 & Foxcote & England & Closed & $\mathrm{D}$ \\
\hline 41 & Quebradona & S. America & Closed & $\mathrm{F}$ \\
\hline 42 & $\mathrm{Cobb}$ & N. Zealand & Closed & $G$ \\
\hline 43 & Selset & England & Closed & $D$ and $H$ \\
\hline
\end{tabular}

* Numbers correspond to those in tables 1-3 in main text.

* Piezometer tip types are illustrated in figs. Bl-B7. 


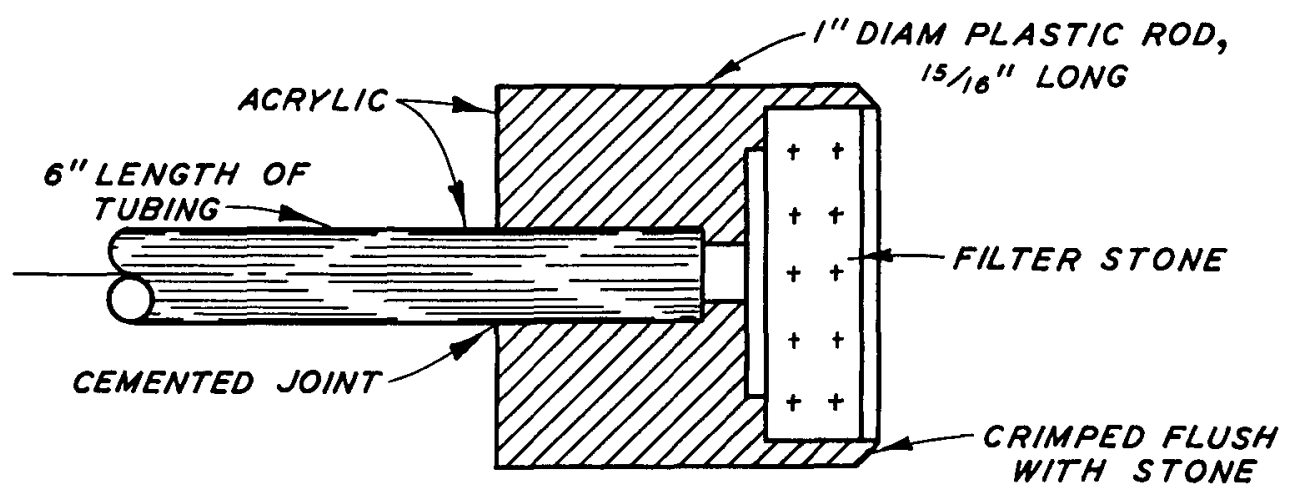

TYPE A, SINGLE-TUBE TYPE

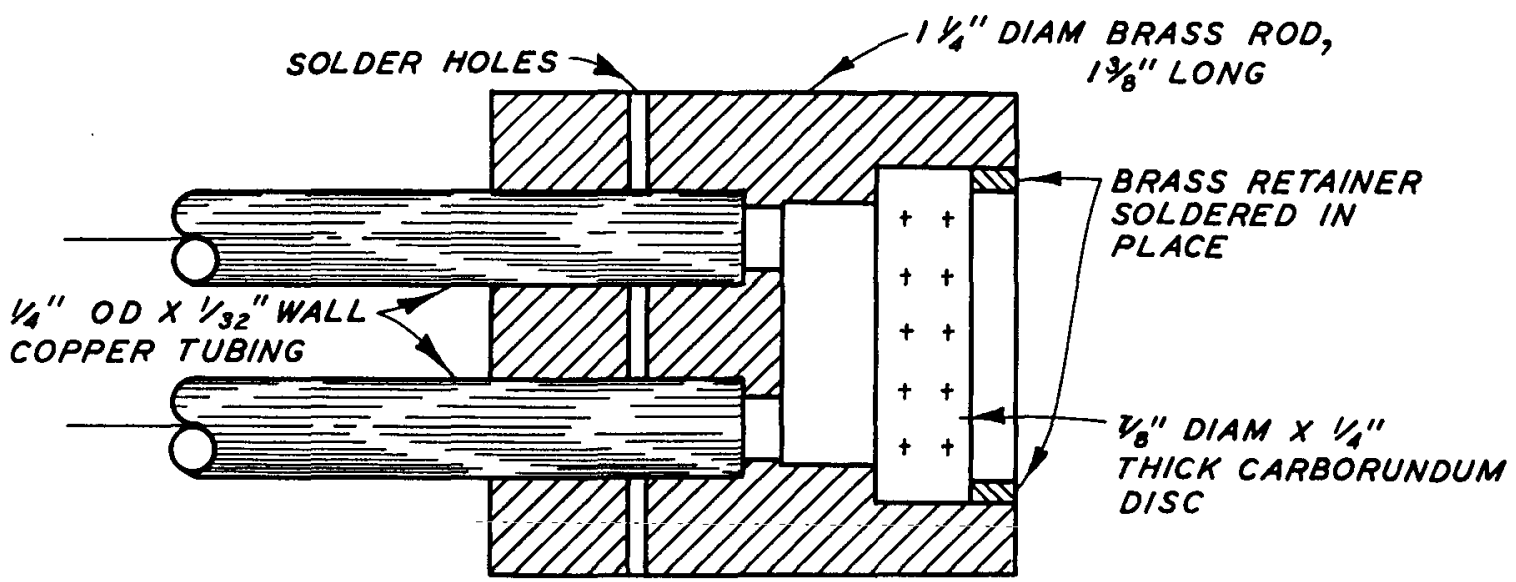

TYPE B, EMBANKMENT TIP

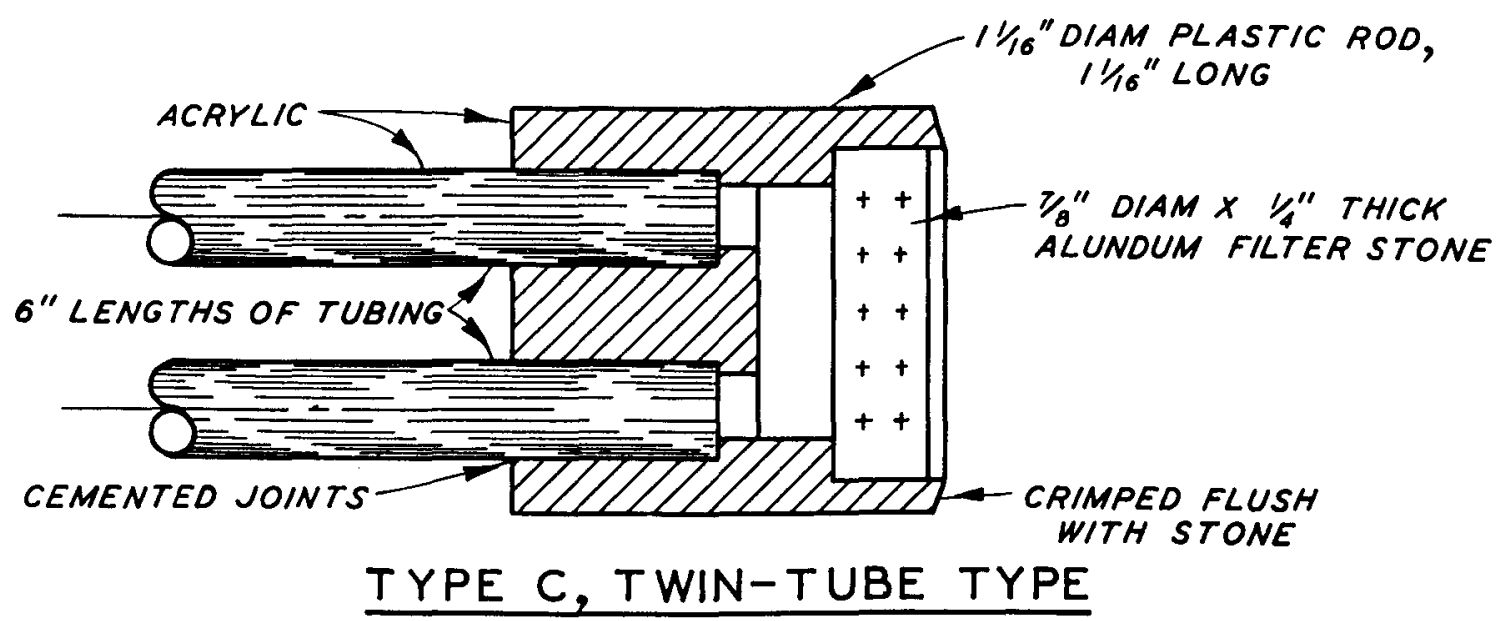

Fig. Bl. Piezometer tip types A, B, and C 

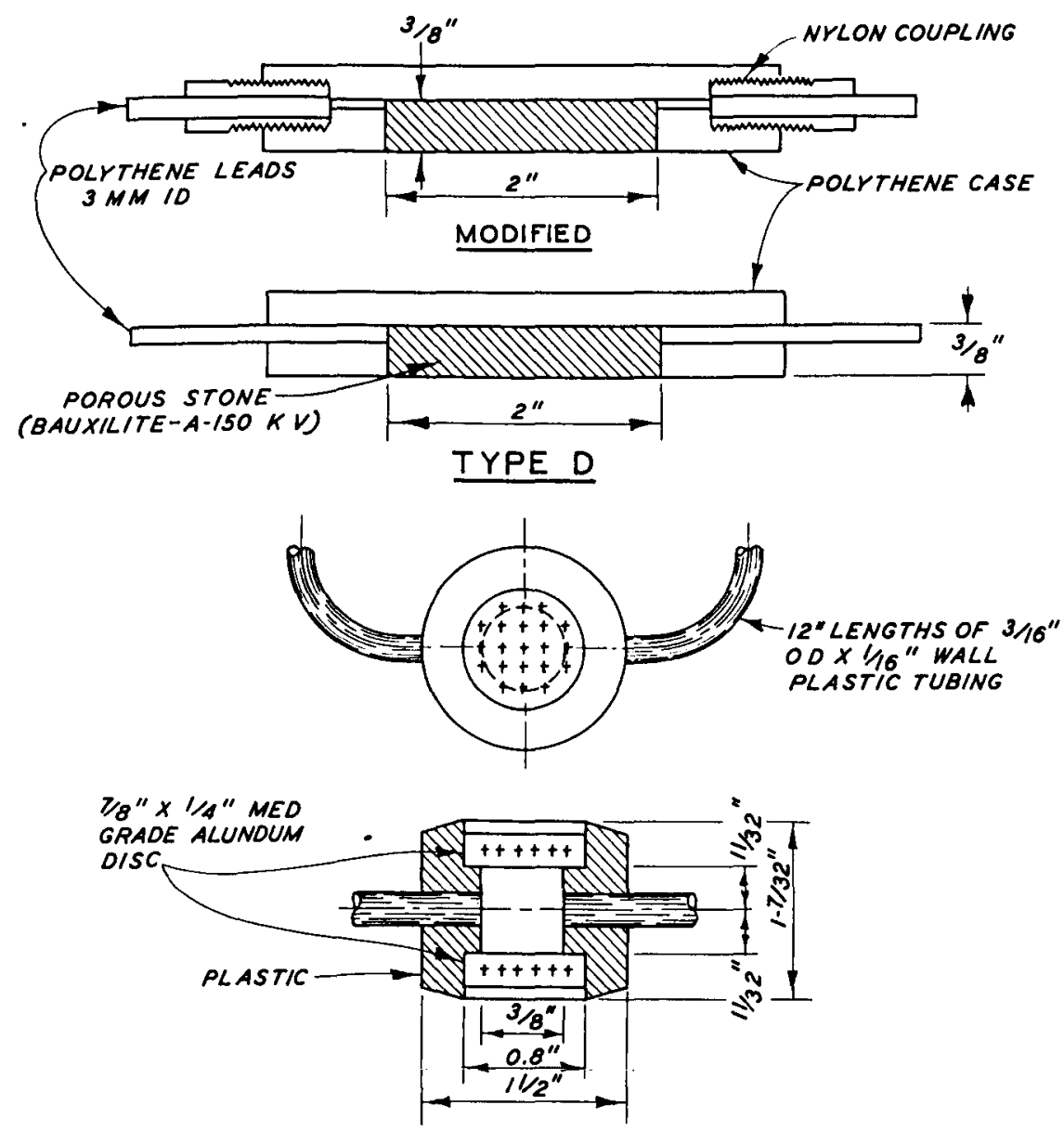

EMBANKMENT TYPE

TYPE F

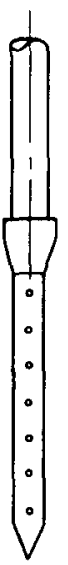

WELL POINT SCREEN

TYPE E

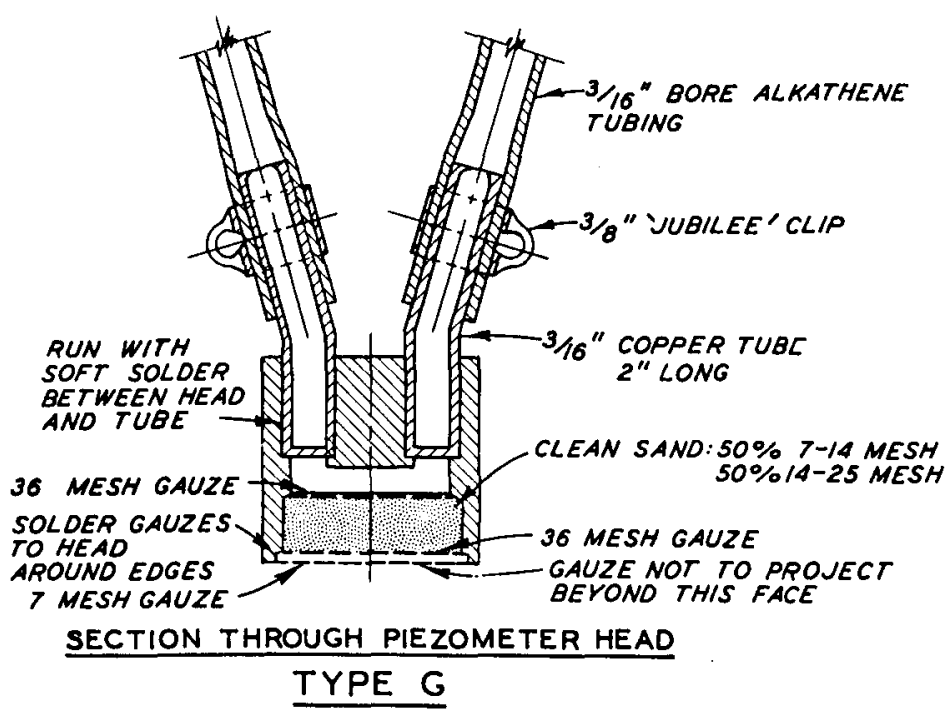

Fig. B2. Piezometer tip types D, F, and $G$, and well point screen type E 


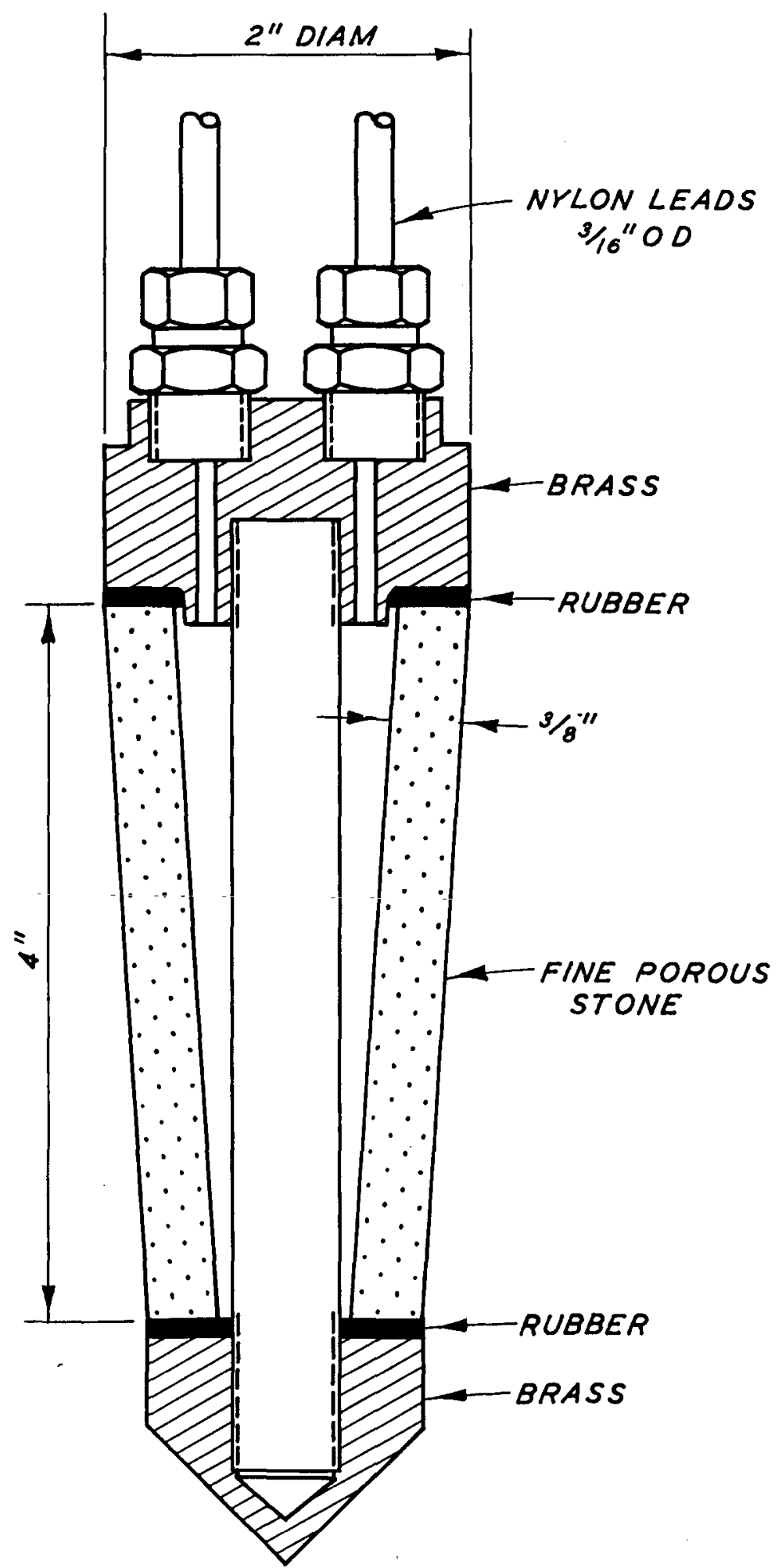

Fig. B3. Piezometer tip type $\mathrm{H}$ 


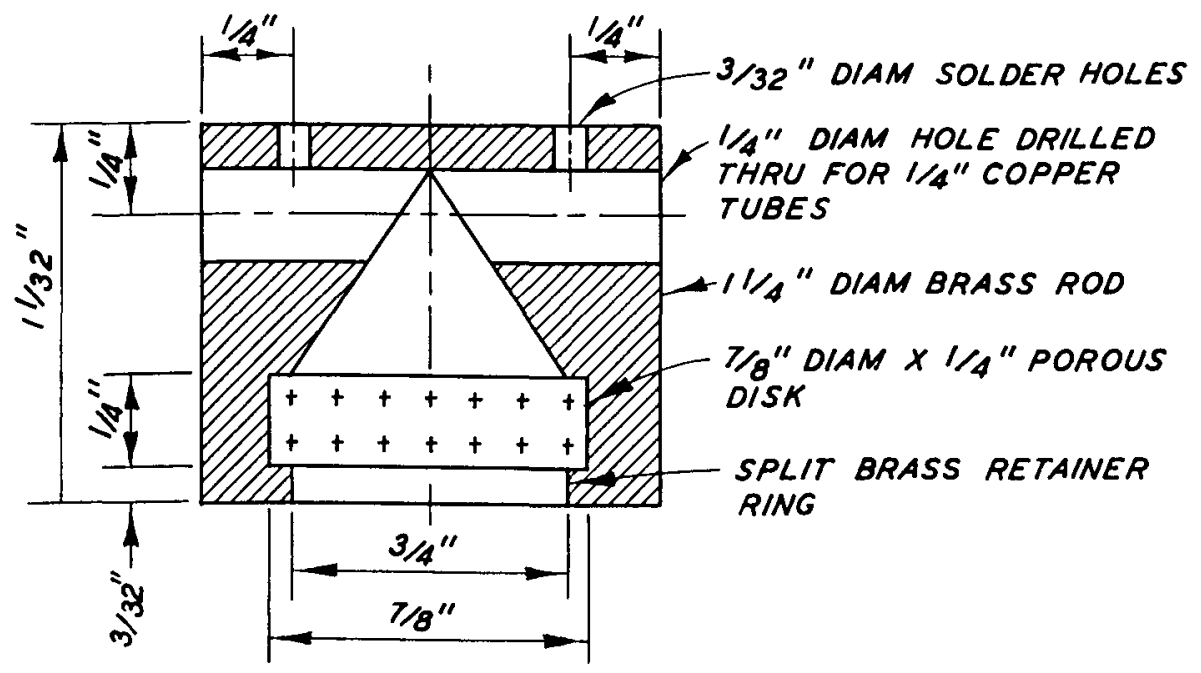

TYPE Ia (CLOSED)

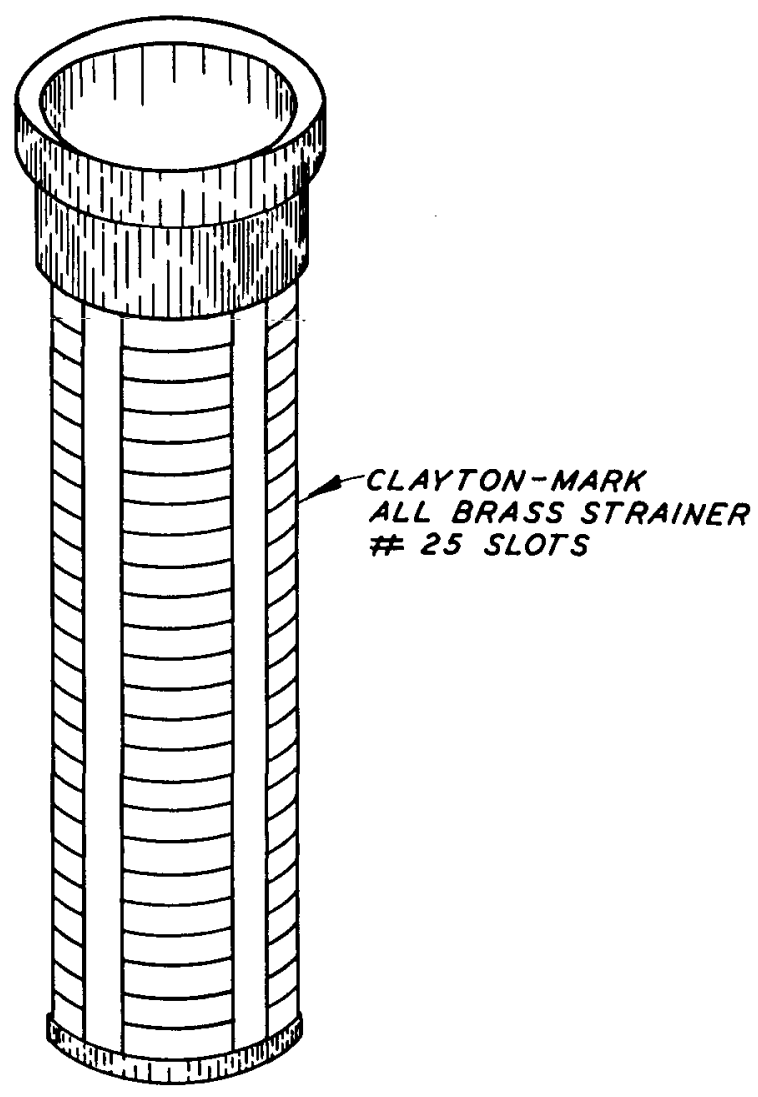

TYPE Ib (OPEN)

Fig. B4. Piezometer tip types $\mathrm{Ia}$ and $\mathrm{Ib}$

BD 

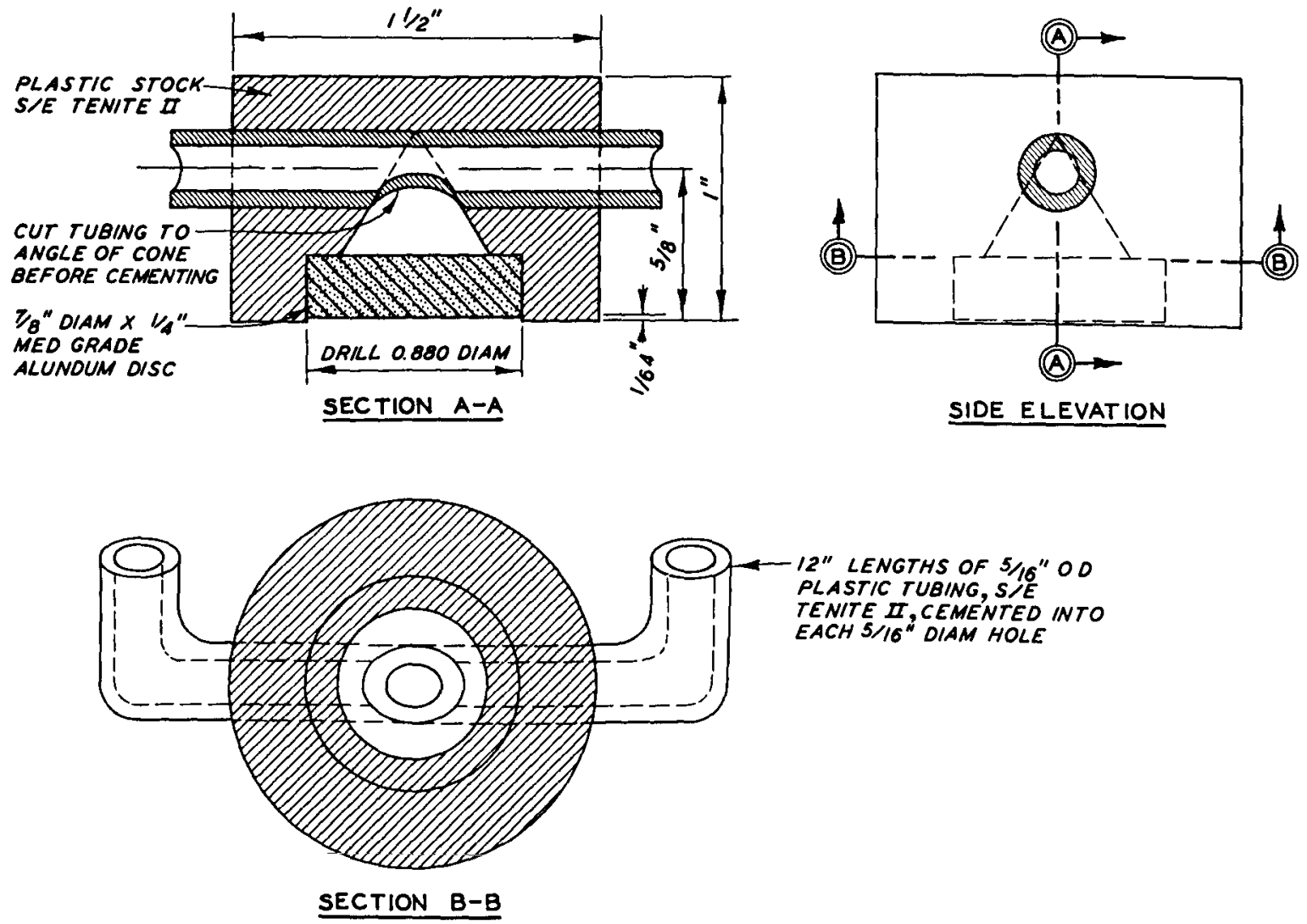

TYPE J

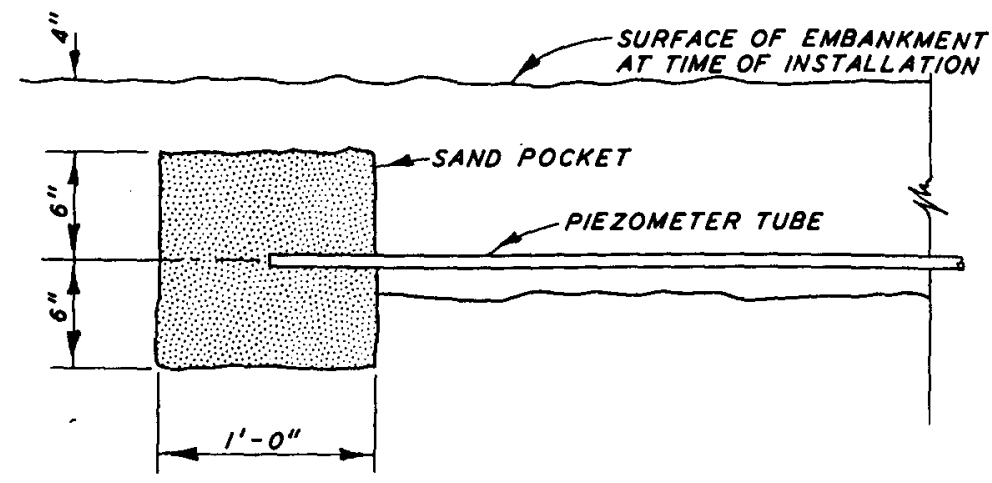

TYPE K

Fig. B5. Piezometer tip types $\mathrm{J}$ and $\mathrm{K}$ 


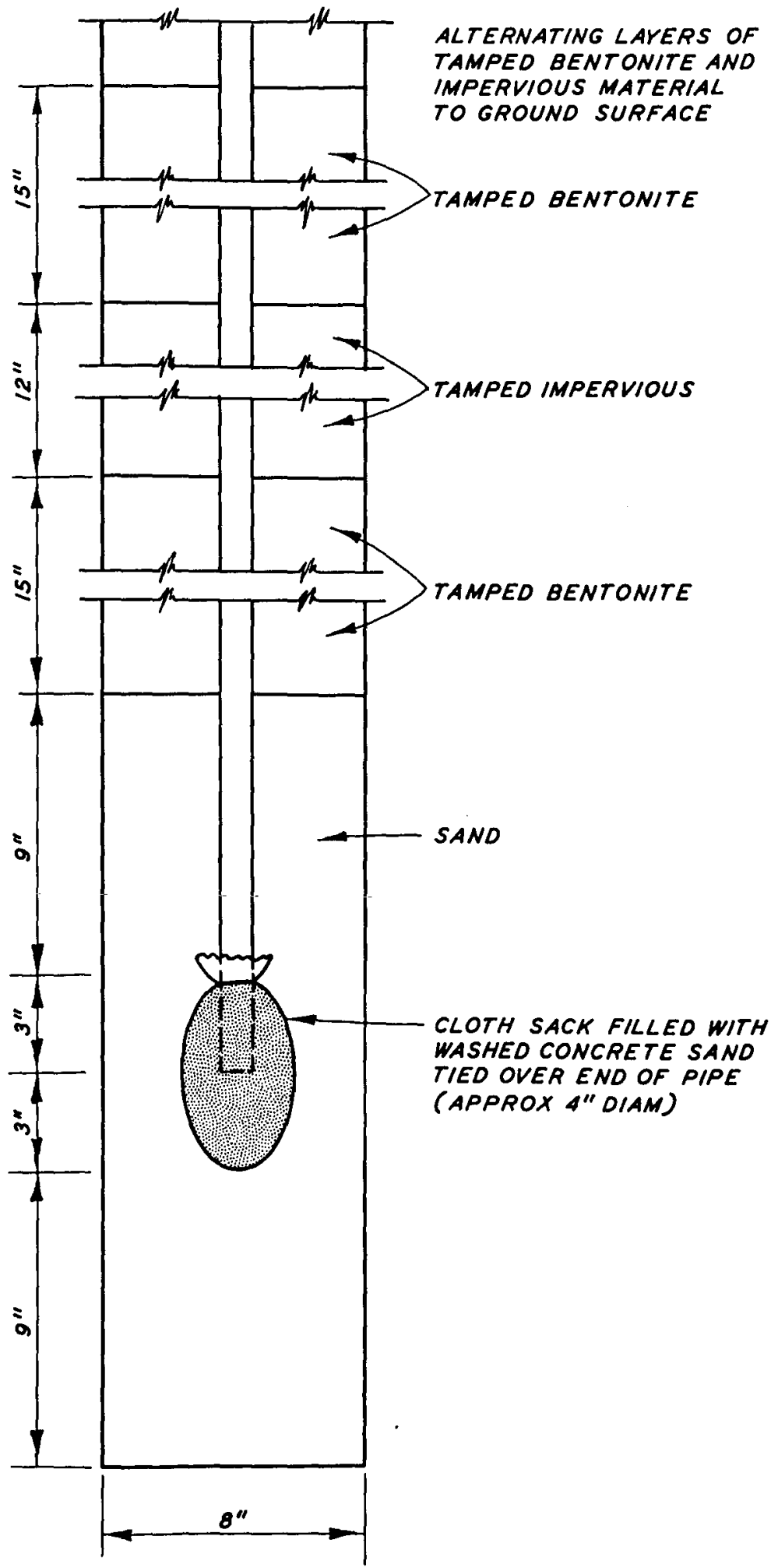

Fig. B6. Piezometer tip type $L$ 

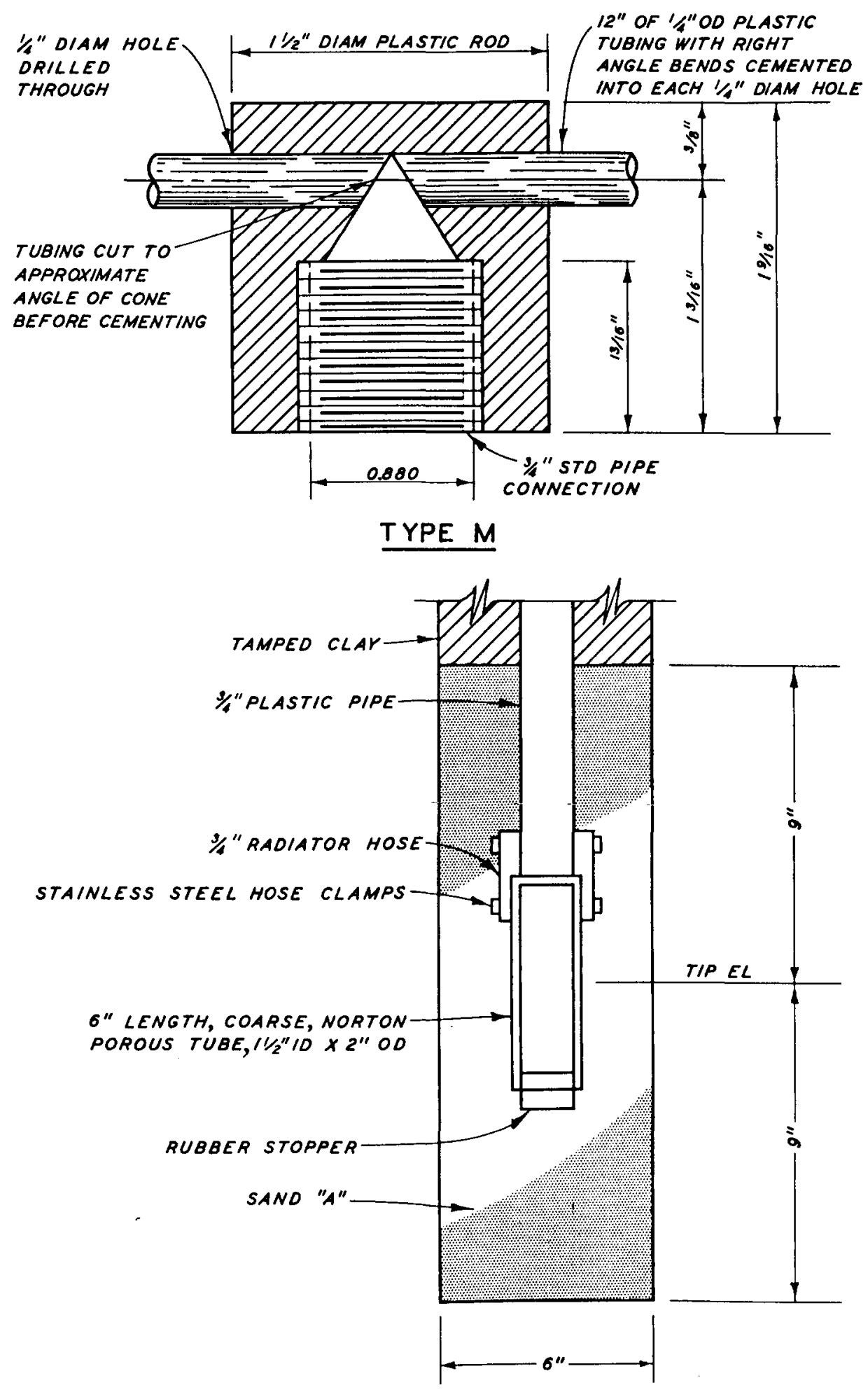

TYPE N

Fig. B7. Piezometer tip types $M$ and $N$ 


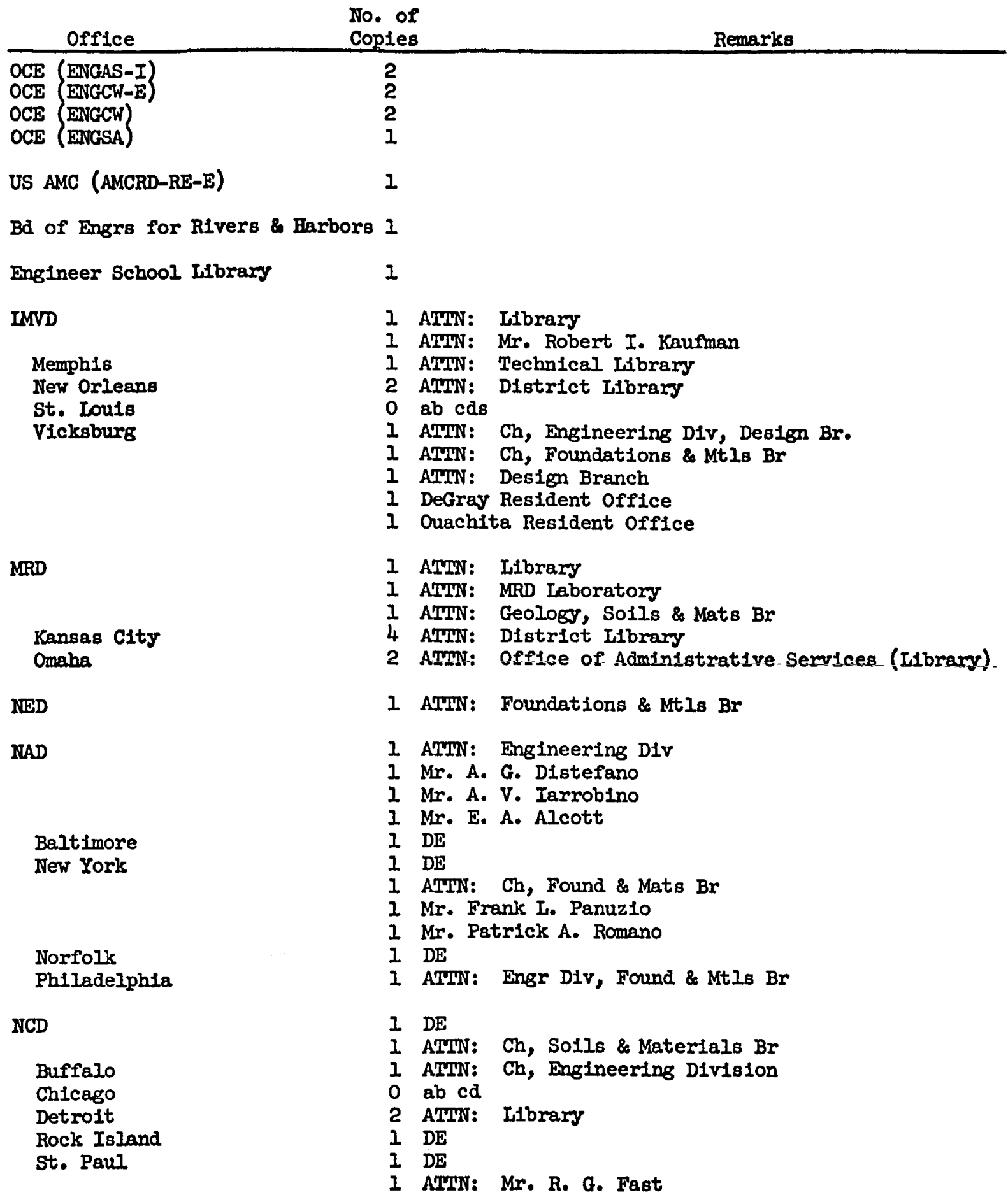




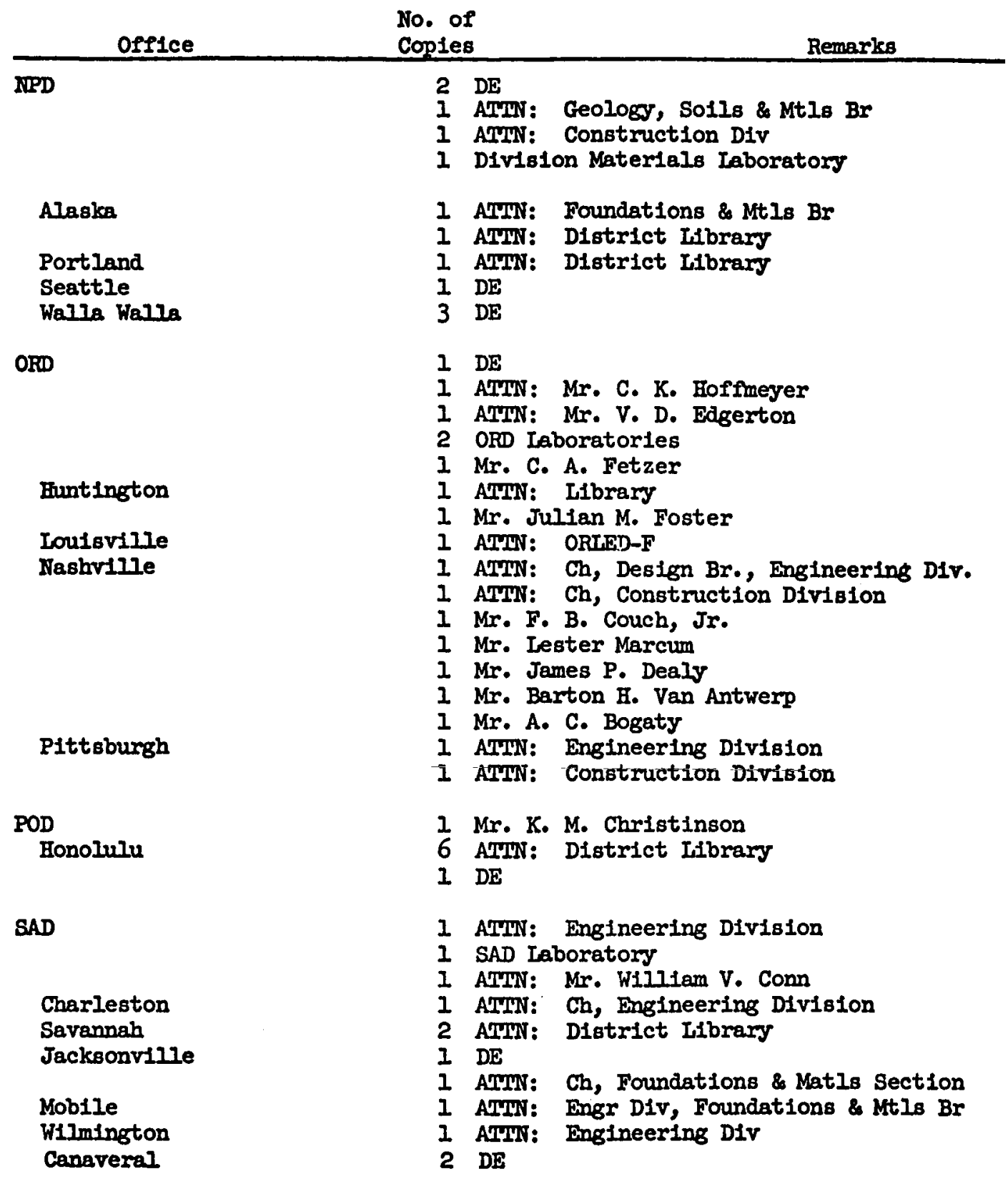




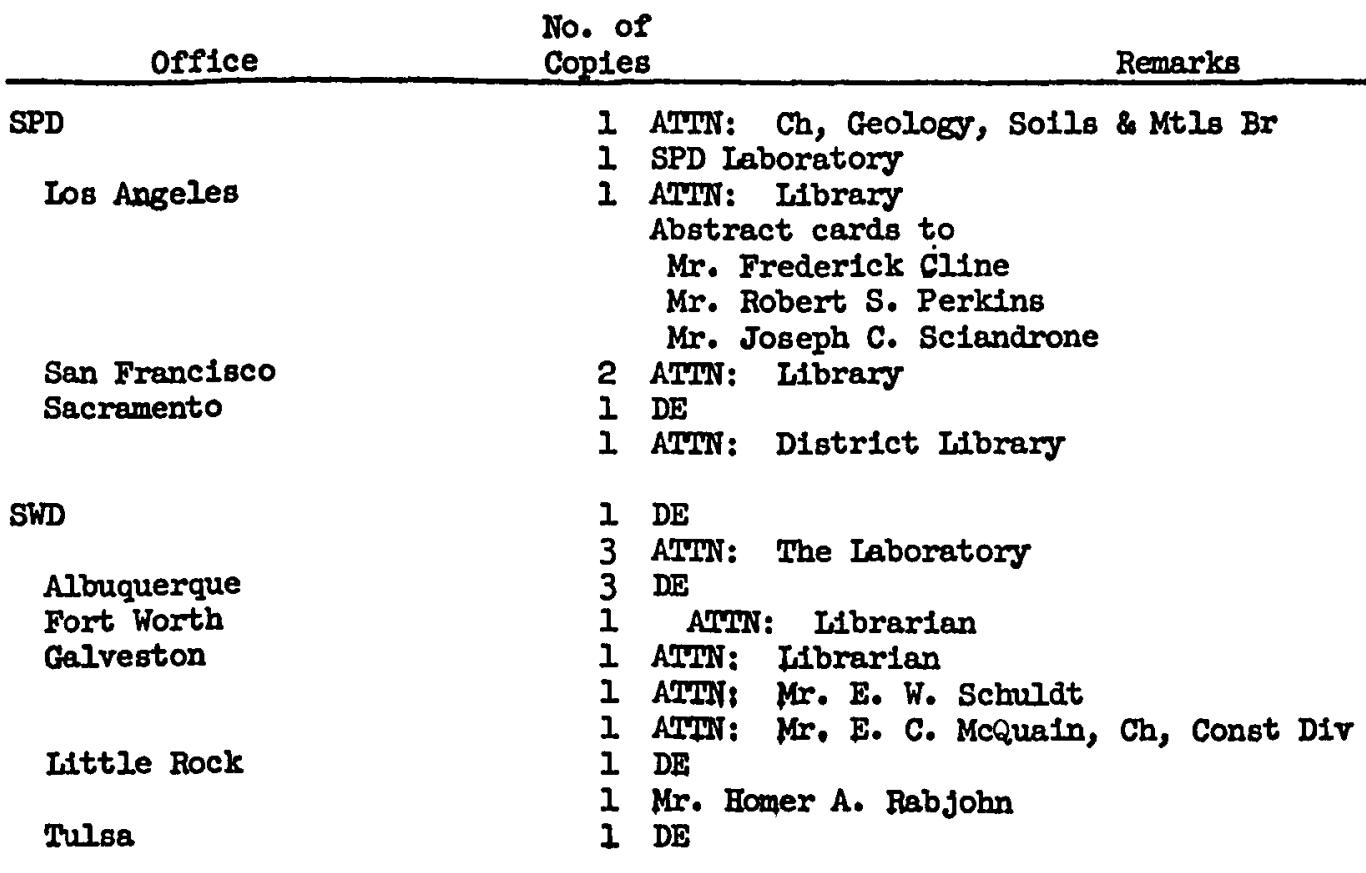

CREL

1

Automatic :

Engineering Societies Iibrary

Lib, Div of Public Documents, US Govt Printing Office

Prof. J. 0. Osterberg, Northwestern University-

MII, Soll Engr Library, Room 1-334, Cambridge, Mass.

The Ifbrary of Congress, Documents Expediting Project, Washington, D. C.

1

1

1

3

Exchange Basis:

Nat1onal Research Council, Otta 2, Canada (ENG-17)

The Exchange Iibrarian, Ministry of Technology at Kingsgate House, Victorla Straet, London, S.W.I, England (ENG-46)

The Institution of Civil Engineers, Westminster, London, S.W.I, England (ENG-47)

Prof. Dr.-Ing. Edgar Schultze, Inst1tut fur Verkehrswasserbau Grundbau und Bodenmechanik, Technische Hochschule, Aachen, Germany (ENG-T7)

Dr. Laurits Bjerrum, Director, Norwegian Geotechnical Institute, Blindern0slo, Norway (ENG-101)

The Itbrary, Royal Institute of Technology, Stockholm, Sweden (ENG-122)

Statens Geotekniska Institut, Banargalan 16, Stockholm, Sweden (ENG-123)

Director, Statens Vaginstitut, Drottning Kristinas vag 25, Stockholm, Sweden (ENG-149)

The Institution of Engineers, Australia (ENG-162)

Dr. J. Brinch Hansen, The Danlsh Geotechnical Institute, 10 Oster Voldgage, Copenhagen K, Denmark (ENG-165)

Prof. J. Verdeyen, UnIversite Libre de Bruxelles, Laboratolre de Mecanique des Sols, Bruxelles, Belgium (ENG-250)

Mr. A. Comon, Chlef of the Information Division, Institute Eduardo Tarroja de Ia Construccion y del Cemeto, Costillares-Chamartin, Madrid, Spain (ENG-263) 
Bxchange Basis (cont'd)

Dept of Civil Englneering and Applied Mechanics, McGill University, ATIN: Prof. Raymond N. Yong, Montreal, Quebec, Canada (ENG-271)

The Chief Iibrarlan, CSIRO, 314 Albert st., East Melboume, C2, Victoria, Australia (ENG-291)

Applied Mechanlcs Reviews, San Antonio, Texas

Department of Civil Engineering, The University of Arizona

Mr. Karl Brenkert, Jr., Engrg Experiment Station, Auburn University

Bureau of Reclamation, Denver, Colorado

Dr. T. I. Wh, California Institute of Technology, Pasadena, Califorala

Fingineering Library, University of California, Berkeley, California

Central Records Ilbrary, Department of Water Resources

Prof. Ronald F. Scott, California Institute of Technology, Division of Engineering, Pasadena, California

Prof. H. R. Nara, Case Institute of Technology, Cleveland, Ohio

Engineering Librarian, Cornell University, Ithaca, New York

Engineering \& Industrial Experiment Station, UnIversity of Florida, Gainesville, Florida

Price Gilbert Memorial Library, Georgia Inst of Technology, Atlante

Mr. Wolfgang M. Freitag, Gordon McKay Library, Harvard UnIversity

Gifts \& Exchange Division, University of Illinols Library, Urbana

Iibrary, Iowa State University of Science and TechnoloBy, Ames, Iowa

Engineering Experiment Station, Kansas State UnIversity of Agriculture and

Applied Sclence, Manhattan, Kansas

Documents Room, University Library, University of Kansas, Lawrence, Kansas

Fritz Engineering Laboratory, Iehigh University, Bethlehem, Pennsylvania

Hydrodynamics Laboratory, 48-209, MII, Cambridge, Massachusetts

MII, Soll Engineering Library, Room 1-334, Cambridge, Massachusetts

Mr. Robert T. Freese, The University of Michigan, Ann Arbor, Michigan

Engineering and Industrial Research station, State College, Mississippi

College of Engineering, University of Missour1, Columbia, Missourl

Mr. Earl J. Randolph, Librarian, The University of Missouri, School of

Mines and Metallurey, Rolla, Missourl

Department of Civil Engineering, New York University, New York, New York

Department of Engineering Research, North Carolina State College, Raleigh, North Carolina

Dr. Robert I. Kondner, The Technological Inst., Northwestern University,

Evanston, Illinols

Gifts and Exchange, Main Iibrary, The Ohio State University, Columbus, Ohio

Engineering Experiment Station, Oregon State University, Corvallis, Oregon

The Engineering Iibrary, Teh Pennsylvania State University, University Park,

Pennsylvania

Peoridicals Checking Files, Purdue University Libraries, Lafayette, Ind.

Engineering Library, Stanford University, Stanford, California

Tennessee Valley Authority

Supervisor of Publications, Texas Engineering Experiment Station, College Station, Texas

Office of Engineering Research, Publications, University of Washington, Seattle, Washington

Albrook Hydraulic Laboratory, Washington State University, Pullman, Wash.

Englneering Library, Mechanical Engineering BIdg., The University of Wisconsin, Madison, Wisconsin 
Exchange Basis (cont'd)

College of Engineering, University of Arkansas, Fayetteville, Ark.

Geology Dept., Tulane University, New Orleans, Ia.

Abstract cards:

CG, Fourth U. S. Army, Fort Sam Houston, Texas, ATMN: AKAFN-OI

Howard-Tilton Memorial Library, New Orleans, Louisiana

Princeton University, Princeton, New Jersey

Duke University Library, Durham, North Carolina

Pennsylvania State University, Serials Record, University Park, Pa.

Loulsiane State University

The Johns Hopkins University Library

University of Kansas Libraries, Lawrence, Kansas

Iaboratorio Naclonal de Engenharla Civil, Lisboa, Portugal

Dept of Civil Engr, Unir of Tokjo, Bunkjo-ka, Tokvo, Japan

Duke University, College of Englneering Iibrary, Durham, N. C.

Dipl.-Ing. H. Kuhn, Schriftleltung Dokumentation Bodermechanik, Siegen, Germany

Mr. M. Ruban, DIv Engr, Laboratorio Regional, Ponts et Chaussees, Cotes-du-ITord, France 
Unclassified

Security Classification

DOCUMENT CONTROL DATA - R\&D

(Security clessification of dltle, body of abstract and indexine annotation must be entered when the overall report is classified) 1. ORIGINATING ACTIVITY (COPOPate author) DA. REPORT SECURITY CLASSIFICATION

U. S. Army Engineer Waterways Experiment Station

Vicksburg, Mississippi Unclassified

3. REPORT TITLE

EMBANKMENT PORE PRESSURES DURING CONSTRUCTION

4. DESCRIPTIVE NOTES (Type of roport and inclusive daton)

Final report

5. AUTHOR(S) (Lost name, first neme, inilial)

Clough, Gerald W.

Snyder, Joseph W.

\begin{tabular}{|c|c|c|}
\hline $\begin{array}{l}\text { 6. REPO RT DATE } \\
\text { MaY } 1966\end{array}$ & $\begin{array}{l}\text { 7a. TOTAL NO. OF PAGES } \\
92\end{array}$ & $\begin{array}{l}\text { 7b. NO. OF REFS } \\
61\end{array}$ \\
\hline $\begin{array}{l}\text { Ba. CONTRACT OR GRANT NO. } \\
\text { b. PROJECT NO. }\end{array}$ & \multicolumn{2}{|c|}{ 90. ORIGINATOR'S REPORT NUMBER(S) } \\
\hline c. ES 531 & \multicolumn{2}{|c|}{$\begin{array}{l}\text { 9 b. OTHER REPOAT NO(S) (A ny othor numbere that may be assignod } \\
\text { this report) }\end{array}$} \\
\hline
\end{tabular}

10. AVAILABILITY/LIMITATION NOTICES

Distribution of this document is unlimited.

11. SUPPL EMENTARY NOTES

12. SPONSORING MILITARY ACTIVITY

Office, Chief of Engineers

Washington, D. C.

13. Aвstract The purpose of this study was to summarize observed pore pressure data from $\mathrm{CE}$ dams and published data from other agencies on methods of predicting and determining the development of pore water pressure in earth dams. A summary of theoretical methods for predicting pore pressures is included to assist in the interpretation of the selected data. Construction characteristics and pore pressure data from $10 \mathrm{CE}$ dams, 24 USBR dams, and 9 foreign dams are summarized and compared in an effort to draw conclusions on construction pore pressures in earth dams. This study determined that because of the numerous factors which influence pore pressure buildup, broad conclusions for all earth dams are very difficult to make and each dam must be treated individually with respect to predicting construction pore pressures. Conclusions indicated as a result of this study are: (a) Provisions for internal drainage effectively relieve construction pore pressures in earth embankments. (b) Pore pressure ratios in embankment materials increase rapidly as placement water content increases, especially above optimum water content. (c) Pore pressures increase with increasing dam height, but even low dams can develop large pore pressures. It is recommended that piezometer installations and data recording be standardized to facilitate obtaining useful information for further understanding of the factors affecting pore pressure development. A selected bibliography of pore pressure literature is included. Appendix $A$ is a tabulation of $C E$ division office responses to the data requests for this study. Appendix B presents sketches of different piezometer tips used in dams included in this study. 


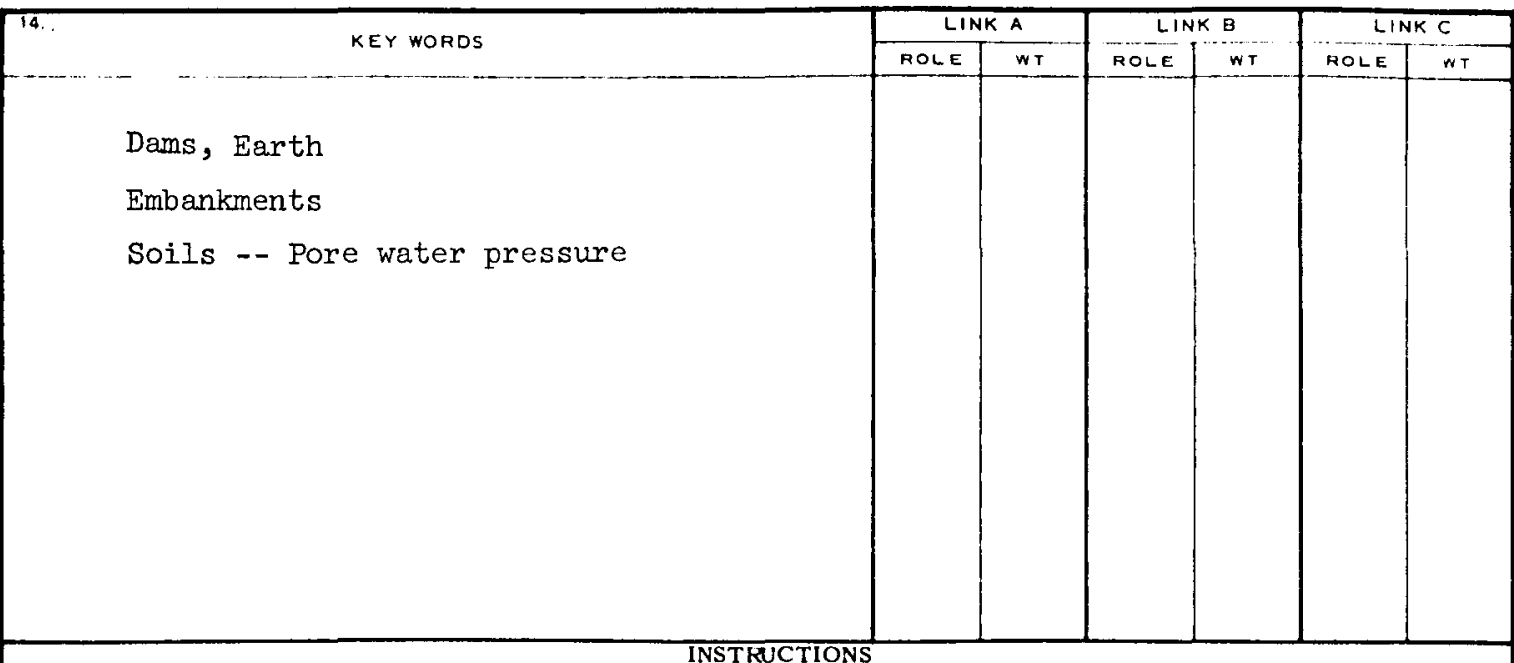

\section{INSTRUCTIONS}

1. ORIGINATING ACTIVITY: Enter the name and address of the contractor, subcontractor, grantee, Department of Defense activity or other organization (corporate author) issuing the report.

2a. REPORT SECURTY CLASSIFICATION: Enter the overall security classification of the report. Indicate whether

"Restricted Data" is included Marking is to be in accordance with appropriate security regulations.

2b. GROUP: Automatic downgrading is specified in DoD Directive 5200.10 and Armed Forces Industrial Manual. Enter the group number. Also, when applicable, show that optional markings have been used for Group 3 and Group 4 as authorized.

3. RFPORT TITLE: Enter the complete report title in all capital letters. Titles in all cases should be unclassified. If a meaningful title cannot be selected without classification, show title classification in all capitals in parenthesis immediately following the title.

4. DESCRIPTIVE NOTES: If appropriate, enter the type of report, e.g., interim, progress, summary, annual, or final.

Give the inclusive dates when a specific reporting period is covered.

5. AUTHOR(S): Enter the name(s) of author(s) as shown on or in the report. Enter last name, first name, middle initial. If military, show rank and branch of service. The name of the principal author is an absolute minimum requirement.

6. REPORT DATE: Enter the date of the report as day, month, year; or month, year. If more than one date appears on the report, use date of publication.

7a. TOTAL NUMBER OF PAGES: The total page count should follow normal pagination procedures, $i, e_{\text {, enter the }}$ number of pages containing information.

7b. NUMBER OF REFERENCES: Enter the total number of references cited in the report.

8a. CONTRACT OR GRANT NUMBER: If appropriate, enter the applicable number of the contract or grant under which the report was written.

8b, \& , \& 8d. PROJECT NUMBER: Enter the appropriate military department identification, such as project number, subproject number, system numbers, task number, etc.

9a. ORIGINATOR'S REPORT NUMBER(S): Enter the official report number by which the document will be ident ified and controlled by the originating activity. This number must be unique to this report.

9b. OTHER REPORT NUMBER(S): If the report has been assigned any other report numbers (either by the originator or by the sponsor), al so enter this number(s).
10. AVAILABILITY/LIMITATION NOTICES: Enter any limitations on further dissemination of the report, other than those imposed by security classification, using standard statements such as:

(1) "Qualified requesters may obtain copies of this report from DDC."

(2) "Foreign announcement and dissemination of this report by DDC is not authorized."

(3) "U. S. Government agencies may obtain copies of this report directly from DDC. Other qual ified DDC users shall request through

(4) "U. S. military agencies may obtain copies of this report directly from DDC. Other qualitied users shall request through

(5) "All distribution of this report is controlled. Qualified DDC users shall request through ."

If the report has been furnished to the Office of Technical Services, Department of Commerce, for sale to the public, indicate this fact and enter the price, if known

11. SUPPLEMENTARY NOTES: Use for additional explanatory notes.

12. SPONSORING MILITARY ACTIVITY: Ent er the name of the departmental project office or laboratory sponsoring (paying for) the research and development. Include address.

13. ABSTRACT: Enter an abstract giving a brief and factual summary of the document indicative of the report, even though it may also appear elsewhere in the body of the technical report. If additional space is required, a continuation sheet shall be attached.

It is highly desirable that the abstract of classified te. ports be unclassified. Fach paragraph of the abstract shall end with an indication of the military security classification of the information in the paragraph, represented as (TS), (S), (C), or $(U)$.

There is no limitation on the length of the abstract. However, the suggested length is from 150 to 225 words.

14. KEY WORDS: Key words are technically meaningful terms or short phrases that characterize a report and may be used as index entries for cataloging the report. Key words must be selecter so that no security classification is required. Idenfiers, such as equipment model designation, trade name, military project code name, gengraphic location, may be used as key words but will be followed by an indication of technical context. The assignment of links, rules, and weights is optional. 